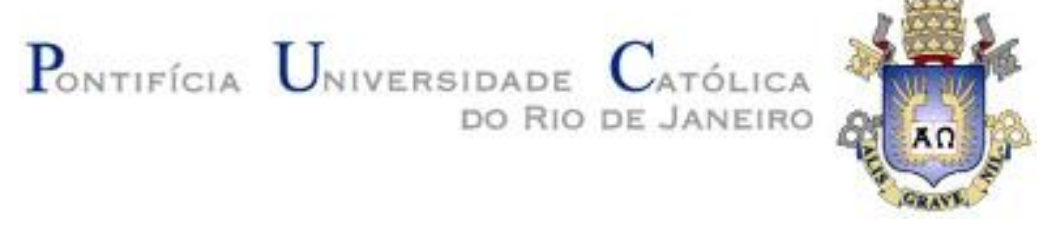

Daniela de Oliveira Pereira

Percepções de universitários sobre o uso de dispositivos móveis de comunicação em atividades de estudo

Dissertação de Mestrado

Dissertação apresentada ao Programa de PósGraduação em Educação do Departamento de Educação da PUC-Rio como requisito parcial para obtenção do grau de Mestre em Educação.

Orientadora: Prof ${ }^{\mathfrak{a}}$ Rosália Maria Duarte

Rio de Janeiro

Junho de 2018 
Daniela de Oliveira Pereira

\section{Percepções de universitários sobre o uso de dispositivos móveis de comunicação em atividades de estudo}

Dissertação apresentada como requisito parcial para a obtenção do grau de Mestre pelo Programa de Pós-Graduação em Educação do Departamento de Educação do Centro de Teologia e Ciências Humanas da PUC-Rio. Aprovada pela Comissão Examinadora abaixo assinada.

Profa. Rosália Maria Duarte

Orientadora

Departamento de Educação - PUC-Rio

Profa. Zena Winona Eisenberg

Departamento de Educação - PUC-Rio

Prof. Alexandre Farbiarz

Departamento de Comunicação Social - UFF

Profa. Monah Winograd Coordenadora Setorial do Centro de Teologia e Ciências Humanas

PUC-Rio

Rio de Janeiro, 29 de junho de 2018 
Todos os direitos reservados. É proibida a reprodução total ou parcial do trabalho sem a autorização da universidade, da autora e da orientadora.

\section{Daniela de Oliveira Pereira}

Graduou-se Bacharel em Comunicação Social (habilitação Jornalismo) pela Escola de Comunicação da Universidade Federal do Rio de Janeiro (UFRJ) em 2004. Tem experiência na cobertura de temas de educação, ciência e tecnologia. É jornalista, desde 2011, da Universidade Federal do Estado do Rio de Janeiro (Unirio).

Ficha Catalográfica

Pereira, Daniela de Oliveira

Percepções de universitários sobre o uso de dispositivos móveis de comunicação em atividades de estudo / Daniela de Oliveira Pereira ; orientadora: Rosália Maria Duarte. - 2018. 120 f. : il. color. ; $30 \mathrm{~cm}$

Dissertação (mestrado) - Pontifícia Universidade Católica do Rio de Janeiro, Departamento de Educação, 2018.

Inclui bibliografia

1. Educação - Teses. 2. Dispositivos móveis de comunicação. 3. Ensino superior. 4. Universitários. 5. Aprendizagem entre pares. 6. Atenção. I. Duarte, Rosália Maria. II. Pontifícia Universidade Católica do Rio de Janeiro. Departamento de Educação. III. Título. 


\section{Agradecimentos}

À minha orientadora, Rosália Duarte, pela generosidade na orientação da pesquisa e pelo incentivo e carinho durante toda a jornada. Suas observações sempre pertinentes e sua capacidade de apontar caminhos foram fundamentais para a construção desta dissertação. Muito obrigada por tudo.

À professora Zena Eisenberg, que contribuiu com seu olhar atento durante a disciplina de Pesquisa, como parecerista do projeto de pesquisa e como integrante da banca de avaliação da dissertação, e ao professor Alexandre Farbiarz, por sua disponibilidade e por aceitar compor a banca. Foi um prazer dialogar com vocês e contar com suas contribuições.

Aos professores do Programa de Pós-Graduação em Educação, pelos momentos de reflexão e troca, e aos funcionários do Departamento de Educação, pelo suporte administrativo.

À PUC-Rio, pelo auxílio concedido, sem o qual cursar o mestrado não teria sido possível.

Aos/às estudantes da Unirio que se disponibilizaram a participar da pesquisa, já que sem vocês ela não teria sido desenvolvida. Nossas conversas foram valiosíssimas e constituem a base deste trabalho. Muitíssimo obrigada a cada um/a.

Aos coordenadores de curso e professores da Unirio que autorizaram a realização da pesquisa e as visitas em salas de aula. Aos colegas da Coordenadoria de Comunicação Social da Unirio, pelo apoio e colaboração durante todo o curso.

À turma de mestrado 2016, pela amizade e pelo apoio mútuo desde o início do curso, e em especial a Bruna e João; aos colegas do Grupem, pelas ricas tardes de segundas, e em especial à Mirna, pelo suporte na reta final; e à doutora Josy Fischberg, por ter me incentivado a fazer a seleção para o mestrado na PUC.

À minha família, em especial minha mãe e minha irmã, pelo carinho e pela torcida em todos os momentos; e à Camila, pela cumplicidade e pelo dom de me fazer rir nas situações mais complicadas. À minha família número 2, Ale, Gi, Carlota e Juju, por vocês terem participado disso tudo de forma tão carinhosa e divertida, do início ao fim. Ao Dudu, por topar todas as maluquices que fizemos para eu cursar o mestrado, por aguentar minhas ausências e por ser meu maior incentivador nos dias bons e ruins. Obrigada por todos os "viu só?" que ouvi nos últimos dois anos e теіо. люблю тебя! 


\section{Resumo}

Pereira, Daniela de Oliveira; Duarte, Rosália Maria (Orientadora). Percepções de universitários sobre o uso de dispositivos móveis de comunicação em atividades de estudo. Rio de Janeiro, 2018. 120p. Dissertação de Mestrado - Departamento de Educação, Pontifícia Universidade Católica do Rio de Janeiro.

O uso frequente de dispositivos móveis de comunicação pode ser observado no cotidiano e gera implicações em diferentes campos, entre eles na Educação. Esta pesquisa teve como objetivo geral identificar percepções de universitários sobre o uso destes dispositivos, e particularmente dos telefones celulares, em atividades de estudo, em diálogo com referenciais teóricos da psicologia sócio-histórica, com foco nas relações entre comunicação e cognição. No desenvolvimento da pesquisa, buscou-se também: descrever os principais modos de uso do celular em atividades de estudo; compreender as motivações para os usos identificados; verificar as percepções de ganhos relacionados à realização de atividades de estudo com uso dos dispositivos; identificar se existem diferenças de usos e de visões entre estudantes das Ciências Exatas e das Ciências Humanas. De caráter qualitativo, a pesquisa teve como procedimentos metodológicos a aplicação de entrevistas semiestruturadas a 20 estudantes de seis cursos de graduação da Universidade Federal do Estado do Rio de Janeiro e a análise de conteúdo de cada uma delas. Os dados produzidos indicam que os estudantes valorizam a aprendizagem entre pares mediada pelos dispositivos móveis de comunicação e reconhecem ganhos advindos das interações que acontecem nos ambientes virtuais. Por outro lado, apontam o uso destes dispositivos como fonte de distração ou de fuga em situações desinteressantes, entediantes ou incômodas em sala de aula; e têm a expectativa de que seus professores desempenhem papel ativo na proposição de atividades que utilizem dispositivos móveis como recurso pedagógico.

\section{Palavras-chave}

Dispositivos móveis de comunicação; ensino superior; universitários; aprendizagem entre pares; atenção. 


\section{Abstract}

Pereira, Daniela de Oliveira; Duarte, Rosália Maria (Advisor). Perceptions of university students on the use of mobile communication devices in study activities. Rio de Janeiro, 2018. 120p. Dissertação de Mestrado Departamento de Educação, Pontifícia Universidade Católica do Rio de Janeiro.

The frequent use of mobile communication devices can be observed in the daily life and generates implications in different fields, among them in Education. This research aimed to identify the perceptions of university students about the use of these devices, specifically mobile phones, in study activities, in dialogue with theoretical references of socio-historical psychology, focusing on the relations between communication and cognition. In the development of the research, we also seek: to describe the main ways of using the mobile phone in study activities; to understand the motivations for identified uses; to verify the earnings perceptions related to the performance of study activities using the devices; to identify if there are differences of uses and visions among students of STEM (Science, Technology, Engineering and Math) and students of Humanities and Social Sciences. As a qualitative study, the research had as methodological procedures the application of semi-structured interviews to 20 students from six undergraduate courses of the Federal University of the State of Rio de Janeiro (Unirio) and the content analysis of each one of them. The data produced indicate that students value peer-to-peer learning mediated by mobile communication devices and recognize gains in interactions that occur in virtual environments. On the other hand, they point to the use of these devices as a source of distraction or escape in situations uninteresting, annoying or uncomfortable in the classroom; and they have the expectation that their teachers play an active role in proposing activities that use mobile devices as a pedagogical resource.

\section{Keywords}

Mobile communication devices; higher education; college students; peer learning; attention. 


\section{Sumário}

1. Introdução 11

1.1 Questões e objetivos da pesquisa 14

$\begin{array}{ll}1.2 \text { Organização textual } & 16\end{array}$

2. Fundamentação teórica e diálogos empíricos 17

$\begin{array}{ll}2.1 \text { Teorias da interação social } & 17\end{array}$

2.2 O campo empírico: alguns achados 22

3. Os caminhos da pesquisa 29

3.1 Instrumentos para produção e análise dos dados 29

3.2 A determinação do campo 31

3.3 O percurso do campo 32

3.4 Perfil dos participantes $\quad 35$

$\begin{array}{ll}3.5 \text { Categorias de análise } & 37\end{array}$

4. O que contaram os estudantes 41

4.1 Sobre os usos do celular em atividades cotidianas 41

4.2 Sobre a relação com o celular 45

4.3 Sobre o que fazem e como percebem o uso do celular $\begin{array}{ll}\text { em atividades de estudo } & 47\end{array}$

4.3.1 Usos do celular em atividades de estudo 48

4.3.1.1 What's up? E aí? $\quad 49$

4.3.1.2 Leitura de textos: na tela ou no papel? 57

4.3.2 Motivações para o uso 60

4.3.2.1 A qualquer hora, em qualquer lugar: a questão $\begin{array}{ll}\text { da mobilidade } & 60\end{array}$

4.3.2.2 Usos em sala de aula $\quad 65$

$\begin{array}{ll}\text { 4.3.3 Percepções sobre o uso } & 67\end{array}$

4.3.3.1 Vantagens e ganhos 68

$\begin{array}{ll}\text { 4.3.3.2 Desvantagens e prejuízos } & 71\end{array}$ 
4.3.4 Atenção $\quad 72$

4.3.4.1 Distração e fuga $\quad 74$

4.3.4.2 "Eu simplesmente tiro": o manejo da atenção 79

4.3.5 Exatas $x$ Humanas $\quad 81$

4.3.5.1 GeoGebra 84

4.3.6 Atuação e postura dos professores $\quad 87$

4.3.7 Facilidade, praticidade e informação 90

5. Aprendizagem entre pares: uma breve reflexão 94

6. Considerações finais 98

7. Referências bibliográficas 102

$\begin{array}{ll}\text { Apêndices } & 114\end{array}$

Apêndice A - Protocolo de entrevista semiestruturada 114

Apêndice B - Termo de Consentimento Livre e Esclarecido - TCLE

Apêndice C - Relação de códigos criados para análise dos dados

Apêndice D - Relação de códigos do grupo 'Aplicativos' criados para análise dos dados 


\section{Lista de imagens}

Imagem 1 - Troca de mensagens em grupo do WhatsApp

Imagem 2 - Estudante com teclado conectado remotamente ao celular

Imagens 3 e 4 - Tela do celular de um dos entrevistados, com o aplicativo GeoGebra em uso

Imagem 5 - Nuvem de palavras 


\section{Lista de quadros}

$\begin{array}{ll}\text { Quadro } 1 \text { - Perfil dos participantes da pesquisa } & 37\end{array}$

Quadro 2 - Categorias e subcategorias criadas para

a análise de conteúdo

Quadro 3 - Frequências de uso do celular em atividades cotidianas (geral)

Quadro 4 - Frequências de uso do celular em atividades cotidianas por área de conhecimento (detalhado)

Quadro 5 - Vantagens e desvantagens do uso do WhatsApp na área da Educação 


\section{Introdução}

Em agosto de 2017, o Instituto Brasileiro de Geografia e Estatística (IBGE) disponibilizou a mais recente estimativa da população do Brasil: somos pouco mais de 207 milhões de pessoas (BRASIL, 2017). No mês seguinte, de acordo com a Agência Nacional de Telecomunicações (Anatel), o país contava com cerca de 241 milhões de linhas móveis em operação - ou, aproximadamente, 116 linhas móveis para cada 100 habitantes. Pelo mundo, segundo dados da União Internacional de Telecomunicações (2017), o número de assinaturas de telefones celulares também já é maior que o total de habitantes, embora muitas pessoas, principalmente nos países em desenvolvimento, permaneçam sem acesso a esses dispositivos ou com restrições de uso.

Ainda que se considerem estas desigualdades de acesso e diferenças nas condições de uso entre as regiões do país e do mundo, e entre cidadãos de diferentes classes sociais e faixas etárias, não se pode negar que os telefones celulares, em especial aqueles com acesso à internet, tiveram nos últimos anos uma massificação em termos de consumo e uso. A evolução tecnológica cada vez mais acelerada, a redução de preços dos aparelhos e a ampliação das redes de conexão, entre outros fatores, fizeram com que esses dispositivos ocupassem posição central na sociedade contemporânea, em que a comunicação é fortemente mediada pela conexão à rede global de computadores (SERRA, 2007).

A possibilidade de acesso à internet contribuiu para a popularização rápida do consumo dos dispositivos móveis de comunicação, sobretudo o telefone celular. No Brasil, o uso desses aparelhos para acessar a rede ultrapassou no ano de 2014 a utilização do computador para o mesmo fim (INSTITUTO BRASILEIRO DE GEOGRAFIA E ESTATÍSTICA, 2016). A mais recente Pesquisa Nacional por Amostra de Domicílios Contínua - PNAD Contínua TIC 2016 registrou que, em 2016, o celular estava presente em 92,6\% dos domicílios do país, e em 60,9\% deles não havia telefone fixo, apenas o dispositivo móvel. Nas regiões Norte e Nordeste, mais de $75 \%$ dos domicílios tinham apenas o telefone móvel celular. A pesquisa observou que em 97,2\% dos domicílios com acesso à internet o celular era utilizado para este fim, seguido por outros equipamentos, como microcomputadores e tablets. 
Em 38,6\% dos domicílios, o celular foi apontado como único meio de acesso à internet. A PNAD Contínua apontou também que, entre os indivíduos com 10 anos ou mais que acessam a internet, 94,6\% o fazem pelo celular, e 33,4\% utilizam somente o dispositivo para este acesso (INSTITUTO BRASILEIRO DE GEOGRAFIA E ESTATÍSTICA, 2018). Na mesma direção, a pesquisa TIC Domicílios 2016, realizada pelo Centro de Estudos sobre as Tecnologias da Informação e da Comunicação (Cetic.br), registrou um aumento do uso do celular para acesso à internet, tendência já apontada nos últimos anos. Do total de participantes, $93 \%$ mencionaram o aparelho como dispositivo principal para acessar a rede, contra 57\% que indicaram o computador (CETIC.br, 2016).

O panorama motiva reflexões sobre as implicações da disseminação do uso dos dispositivos móveis de comunicação, especialmente os celulares, em diferentes áreas - dos negócios, da cultura, da saúde, entre outros. Ao ingressar no mestrado em Educação, em 2016, e ao longo do curso, minha inquietação acerca das relações que mantemos com os dispositivos móveis de comunicação - que têm assumido presença constante na vida de quase todos nós, quer percebamos ou não - tomou forma e se consolidou no projeto de investigar a utilização desses dispositivos em atividades relacionadas ao estudo.

Neste contexto fortemente marcado pela presença das tecnologias da informação e comunicação no cotidiano, as relações entre tecnologia e aprendizagem têm sido objeto de discussões em diferentes campos da educação (BANNELL et al., 2016). Um dos aspectos que mobilizam questões diz respeito às possibilidades de uso dessas tecnologias para favorecer as práticas de estudo e a aprendizagem. O tema aparece na pauta de instâncias como a Unesco (Organização das Nações Unidas para a Educação, a Ciência e a Cultura), que, em 2014, divulgou um guia no qual aponta diretrizes para políticas voltadas à aprendizagem móvel, desenvolvidas a partir da consulta com especialistas de mais de 20 países. $\mathrm{O}$ estudo reúne exemplos positivos de iniciativas praticadas em diferentes regiões do mundo, relacionadas ao uso dos aparelhos móveis, em sala de aula ou fora dela, com fins de aprendizagem (UNESCO, 2013).

A pesquisa Juventude Conectada 2 (FUNDAÇÃO TELEFÓNICA, 2016), desenvolvida com jovens entre 15 e 29 anos, obteve resultados similares aos da PNAD Contínua e da TIC Domicílios: a maioria (85\%) afirmou ter o celular como equipamento preferencial de acesso à internet. $\mathrm{O}$ percentual representou um 
aumento de $102 \%$ frente à edição anterior do estudo, realizada em 2013. No que se refere a atividades relacionadas a treinamento e educação, $52 \%$ dos jovens disseram utilizar o celular para realizar pesquisas para a escola/faculdade e $63 \%$ registraram o uso do aparelho para fazer cursos online.

Realizada desde 2011 pelo Cetic.br, a Pesquisa sobre o uso das Tecnologias de Informação e Comunicação nas escolas brasileiras - TIC Educação investigou pela primeira vez em 2016 a utilização dos celulares por alunos em atividades escolares. $74 \%$ dos estudantes do $2^{\circ}$ ano do ensino médio e $59 \%$ dos que frequentam turmas de $9^{\circ}$ ano do ensino fundamental afirmaram já terem utilizado o dispositivo por solicitação de algum professor. Entre os docentes que participaram da pesquisa, 91\% disseram utilizar a internet no celular e $49 \%$ deles afirmaram que utilizam o aparelho para atividades realizadas com os alunos.

Bonilla e Pretto (2015) destacam que as tecnologias são fundamentais para uma produção de conhecimento aberta e colaborativa, que permitam a participação de estudantes, professores e comunidade na construção dos processos educacionais. Os autores ressaltam que a era digital potencializa o que Pierre Lévy definiu como inteligência coletiva, para se referir ao "engajamento de coletivos em torno de projetos, que colocam em sinergia seus saberes, competências, imaginações, energias" (BONILLA; PRETTO, 2015, p. 30). Jacks e Schmitz (2018) apontam para uma reconfiguração da sociabilidade, principalmente no uso que os jovens fazem das redes sociais.

Pela tecnologia eles [os jovens] próprios reúnem seus interesses: trabalho e ócio, informação e consumo, pesquisa e jogo. Pelas redes também fazem política, decidem, divertem-se, jogam, exploram a estética e o lúdico. Permitem ainda que a multiplicidade de telas com que convivem atravesse e reconfigure as experiências da rua, já que não estão mais necessariamente reunidos, mas interconectados. (JACKS; SCHMITZ, 2018, p. 127)

Tendo em vista a constatação de que os jovens estão cada vez mais conectados pela internet e que têm o celular como principal dispositivo tecnológico de comunicação, considerou-se pertinente para esta dissertação refletir sobre a utilização desses dispositivos como recurso para estudo por iniciativa própria dos alunos - ou seja, em atividades não necessariamente sugeridas ou demandadas pelos professores. Como observa Pinto (2017), não é possível, ao pensar em 
processos formativos, desconsiderar a forte presença dos meios na vida cotidiana, sobretudo aqueles que permitem o acesso à internet - ainda que não haja respostas para todas as perguntas.

O fato de podermos encontrar as respostas para nossas mais variadas dúvidas navegando pela internet sugere que há algo novo, que está em construção, na interface entre os seres humanos e o conhecimento que perpassa essas tecnologias, sua acessibilidade e não só a disponibilidade dos conteúdos informacionais que nela circulam, mas a credibilidade que possuem. Tendemos a confiar. Acreditamos nas respostas que ela nos fornece, mesmo sem saber ao certo a procedência e a autoria de seu conteúdo. (PINTO, 2017, p.20)

Na mesma direção, Martín-Barbero (2014) pondera que não se pode pensar a educação sem considerar concepções e processos de formação característicos da sociedade em rede, em que a mobilidade e a ubiquidade aparecem como aspectos fundamentais - podemos estar em qualquer e em todos os lugares, a qualquer e a todo momento:

Hoje, a 'idade para aprender são todas', e o lugar pode ser qualquer um - uma fábrica, um hotel, uma empresa, um hospital -, os grandes e pequenos meios ou a internet. Estamos passando de uma sociedade com sistema educativo a uma sociedade educativa, ou seja, cuja rede educativa atravessa tudo: o trabalho e o ócio, o escritório e o lar, a saúde e a velhice. (MARTÍNBARBERO, 2014, p.10)

\section{1}

\section{Questões e objetivos da pesquisa}

Face ao panorama apresentado, foram formuladas as questões que orientaram esta pesquisa: como os estudantes utilizam o celular para estudo, especialmente aqueles que têm maior autonomia no estudo, como é o caso dos alunos do ensino superior? O que apontam como vantagens para utilizar o dispositivo com esta finalidade? E o que percebem como desvantagens? Como avaliam os ganhos obtidos com esse uso? Há diferenças de usos e de visões acerca dos ganhos entre universitários de diferentes áreas do conhecimento? 
Nessa perspectiva, o desenvolvimento desta pesquisa teve como objetivo geral descrever e analisar a percepção ${ }^{1}$ de jovens universitários sobre o uso que fazem dos dispositivos móveis de comunicação, particularmente o celular, em atividades de estudo. A investigação foi conduzida de modo a captar o ponto de vista e a perspectiva do estudante usuário destes dispositivos.

Os objetivos específicos da pesquisa foram: 1) Descrever os usos mais recorrentes do celular para fins de estudo entre jovens universitários; 2) Compreender as principais motivações dos estudantes para utilização dos dispositivos nessas atividades; 3) Analisar as percepções dos ganhos obtidos nos usos identificados; 4) Identificar semelhanças e diferenças de usos e de visões dos estudantes relacionadas às distintas áreas de conhecimento dos cursos aos quais estão vinculados.

Para produzir resultados que permitissem alcançar os objetivos propostos, realizou-se uma investigação com estudantes de cursos de graduação presencial da Universidade Federal do Estado do Rio de Janeiro (Unirio) pertencentes a duas grandes áreas do conhecimento: Ciências Exatas e Humanidades.

Embora existam trabalhos relacionados à aprendizagem móvel e ao uso de dispositivos móveis para atividades relacionadas ao estudo, como será detalhado no capítulo a seguir, poucos descrevem como esses aparelhos são utilizados por estudantes universitários para apoio à aprendizagem, como observam Gikas e Grant (2013), Dukic, Chiu e Lo (2015), entre outros. Assim, justifica-se o desenvolvimento de uma pesquisa que resulte em dados que possam ser utilizados como fonte de comparação com outros estudos, realizados com perfis distintos de participantes, como sugerem Briz-Ponce e Juanes-Méndes (2015). Esta pesquisa vai ao encontro também das reflexões de Munguía (2017), que defende uma investigação sobre as características tecnológicas dos estudantes antes da proposição de ações voltadas ao uso de dispositivos digitais portáteis na educação.

1 O termo percepção será utilizado, ao longo desta dissertação, no sentido etimológico de "compreensão, faculdade de perceber", conforme indica o Grande Dicionário Houaiss, disponível em <https://houaiss.uol.com.br>, acesso em 10 mar. 2018. 


\section{2}

\section{Organização textual}

A dissertação está organizada em seis capítulos, além desta introdução e dos elementos pré e pós-textuais. No capítulo 2 estão dispostas as perspectivas de diálogos empíricos e teóricos, com a apresentação de referenciais teóricos que apoiaram a discussão dos dados produzidos e a descrição de pesquisas sobre o uso de dispositivos móveis, em especial o celular, no ensino superior.

O capítulo 3 apresenta os caminhos da pesquisa, com a descrição dos procedimentos metodológicos adotados - os instrumentos utilizados para produção e análise dos dados, a determinação do campo e o percurso realizado. No capítulo 4 são descritos e discutidos os dados produzidos a partir das entrevistas com relação ao uso que os estudantes fazem dos celulares para estudo. O capítulo 5 reflete, a partir dos resultados, sobre a questão da aprendizagem entre pares, e o capítulo 6 reúne as considerações finais. 


\section{2 \\ Fundamentação teórica e diálogos empíricos}

\section{1}

\section{Teorias da interação social}

As relações da humanidade com as tecnologias remontam aos primeiros artefatos criados e manipulados de modo a permitir/facilitar a realização de alguma tarefa, ou para possibilitar a interação entre os indivíduos. Desde as pinturas rupestres e os sinais de fumaça, passando por instrumentos de comunicação escrita (como a prensa de Guttemberg), falada e audiovisual (telefone, rádio e televisão) até a internet e os dispositivos móveis, o homem sempre utilizou a tecnologia para se comunicar (IGLESIAS, 2009) e também para ampliar suas capacidades cognitivas e facilitar seus modos de vida (BANNELL, 2017).

No livro Os meios de comunicação como extensões do homem, publicado em 1964, Marshall McLuhan reflete sobre as consequências sociais e pessoais das tecnologias na vida de todos aqueles que as têm como extensões de si, considerando essas extensões como instrumentos que possibilitam a tradução de conhecimentos e experiências em outros novos (SERRA, 2007). Dentre suas contribuições à teoria dos meios, McLuhan (2007) sugere que o mais importante não é necessariamente o conteúdo (mensagem), mas sim a possibilidade de o aparato tecnológico (meio) interferir e modificar as relações e percepções humanas - daí a conhecida expressão “o meio é a mensagem".

Com base na perspectiva proposta por McLuhan, é possível refletir sobre como a evolução dos meios de comunicação e das tecnologias em curso desde o fim do século $\mathrm{XX}$, e que se desenvolve com mais profundidade e rapidez desde os primeiros anos do século atual, tem transformado as relações sociais e as formas tradicionais de comunicação. Sujeitos que antes atuavam apenas ou prioritariamente como usuários de tecnologia e consumidores de informação deparam-se com as oportunidades de produção de conhecimento, de compartilhamento e participação, de criação e afirmação cultural. O que foi de propriedade quase que exclusiva dos meios de comunicação - a capacidade de expressar publicamente uma opinião e atingir um público amplo, que vai muito além das relações locais - está hoje ao alcance de muitos, por meio de recursos de 
participação na internet, como redes sociais, blogs, aplicativos e programas de mensagens instantâneas, entre outros. A cultura digital ampliou, principalmente por meio das mídias sociais interativas, as possibilidades de se fazer ouvir e de engajamento pessoal. Estas interações com as tecnologias digitais presentes na vida cotidiana fazem parte do que Martín-Barbero (2000, p. 54) denominou ecossistema comunicativo, no qual os jovens aparecem mais facilmente inseridos: "Eles têm maior empatia cognitiva e expressiva com as tecnologias e com os novos modos de perceber o espaço e o tempo, a velocidade e a lentidão, o próximo e o distante". Nesse sistema, a comunicação e a troca de informação e conhecimento acontecem em ambientes difusos, menos centrados em "lugares sagrados" (MARTíNBARBERO, 2000, p. 55) ou figuras de autoridade.

Muitas são as áreas da sociedade impactadas pelas tecnologias digitais (SELWYN, 2017), entre elas a seara política, com a influência das mídias sociais em campanhas eleitorais, por exemplo; o campo econômico, a julgar pela relevância das empresas do Vale do Silício no cenário mundial; e o terreno cultural, com as mudanças nas formas de lazer e entretenimento. Por outro lado, é necessário considerar que nem todos têm oportunidades iguais frente às tecnologias, ou dispõem das habilidades requeridas para lidar com elas (JENKINS; GREEN; FORD, 2014). Daí a importância do letramento multimidiático, promovido por meio de práticas pedagógicas que desenvolvam não apenas habilidades de leitura e escrita na internet, mas também proporcionem uma reflexão sobre o papel da tecnologia na sociedade e apontem as possibilidades advindas do uso crítico dos recursos tecnológicos disponíveis.

As questões relacionadas à onipresença das tecnologias mediadoras da comunicação na sociedade e nas relações humanas remetem à concepção de sociação formulada por Simmel (2000), que compreende a vida social como algo relacionado à interação entre indivíduos, que ocorre a partir de impulsos, interesses ou finalidades específicas. Para o autor, os fatores de sociação (entre eles "a técnica", a tecnologia) só efetivamente se constituem como tal quando possibilitam ao indivíduo interagir com outros.

A sociação é, portanto, a forma (que se realiza de inúmeras maneiras distintas) na qual os indivíduos, em razão de seus interesses - sensoriais, ideais, momentâneos, duradouros, conscientes, inconscientes, movidos pela causalidade ou 
teleologicamente determinados,- se desenvolvem conjuntamente em direção a uma unidade no seio da qual esses interesses se realizam. (SIMMEL, 2000, pp. 60-61)

Ao permitir a interação entre muitos indivíduos com interesses comuns, seja pelo viés do entretenimento ou, no caso do uso em atividades de estudo, para obter rapidamente alguma informação, compartilhar algum conteúdo ou resolver determinado exercício, a internet e, mais especificamente, as redes sociais e os aplicativos de comunicação instantânea acessados via dispositivos móveis de comunicação propiciam a sociação nos termos propostos por Simmel. Neste processo de trocas o indivíduo, em interação com o outro, é capaz de se transformar e transformar seu entorno.

A interação social é uma das bases das teorias da psicologia sócio-histórica ${ }^{2}$, a qual compreende o desenvolvimento e o comportamento humano como algo que se fundamenta no social, na história e na cultura (IAROCHEVSKI, 2007, apud PRESTES, 2010) - daí sua denominação. O homem, sob esta ótica, é um ser social e suas relações com o mundo fazem parte de seu desenvolvimento. Pino (1993) enumera três pressupostos básicos da perspectiva sócio-histórica: 1) a relação do homem com a atividade de trabalho, pela qual há uma transformação da natureza e do próprio homem; 2) a natureza e a origem social de todas as funções psíquicas, ou seja, o psiquismo humano se constitui a partir do meio sociocultural; 3) a mediação de todas as atividades desenvolvidas pelo homem por instrumentos técnicos e por sistemas de signos.

\begin{abstract}
A interação social é condição permanente de existência do sujeito, a qual se concretiza numa constante relação com os outros. A interação social, como sinônimo de intersubjetividade, e não de qualquer outra modalidade relacional, constitui o próprio modo de ser social do homem, a expressão de sua natureza e origens sociais. (PINO, 1993, p. 57).
\end{abstract}

Em seus estudos sobre a formação social da mente, Lev Vigotski ressalta que as relações sociais humanas se refletem no desenvolvimento cognitivo, como

2 Este campo é também denominado na literatura como psicologia sócio-histórica-cultural ou psicologia histórico-cultural. Nesta dissertação, optou-se pela denominação psicologia sóciohistórica, adotada por algumas das referências bibliográficas utilizadas, como Pino (1993) e Bannell et al. (2016). 
resumem John-Steiner e Souberman (2007, p. 165): "um indivíduo tem a capacidade de expressar e compartilhar com os outros membros de seu grupo social o entendimento que ele tem da experiência comum ao grupo". Nesta perspectiva, um dos aspectos centrais da obra de Vigotski é o conceito de mediação, a partir do qual se entende que o desenvolvimento cognitivo, a construção do pensamento e do conhecimento e a aprendizagem são mediados por elementos presentes nas relações sociais. A mediação se dá por meio de instrumentos técnicos e sistemas de signos (PINO, 1993), que possibilitam ao homem uma relação com o mundo material e a transformação da realidade. Assim, a mediação permite as ligações "entre sujeitos e objetos, entre estados internos (comportamentais ou psicológicos) e práticas externas" (ALEVIZOU, 2017, p. 310).

A importância dos processos de aprendizagem com base na interação social é enfatizada por Vigotski (OLIVEIRA, 1998), para quem o desenvolvimento dos indivíduos está relacionado com o ambiente sociocultural em que eles vivem e com o suporte que recebem dos demais. Essa ótica fundamenta o conceito de zona de desenvolvimento proximal, ou iminente ${ }^{3}$, pelo qual Vigotski defende que a instrução, "ao ser realizada em uma ação colaborativa, seja do adulto ou entre pares, cria possibilidades para o desenvolvimento.” (PRESTES, 2012, p. 168). Ainda que o conceito tenha sido elaborado a partir do desenvolvimento infantil, entende-se que ele pode ser aplicado aos indivíduos nas diferentes fases da vida (DAMIANI, 2008).

As tecnologias de informação e comunicação podem ser compreendidas, sob a perspectiva sócio-histórica, como instrumentos que promovem o desenvolvimento cognitivo, como observa Silva (2016).

\begin{abstract}
Apesar dos autores desta vertente teórica terem vivido em um momento histórico em que tecnologias digitais, como o computador, ainda não existiam, a forma como tratam elementos fundamentais à compreensão do homem - questões sociais, históricas e culturais - em relação aos seus processos de desenvolvimento cognitivo nos permitem elaborar um paralelo teórico sobre esta ferramenta em nossos dias e os novos modos de aprender. (SILVA, 2016, p. 61).
\end{abstract}

3 Prestes (2012) defende que a tradução mais próxima ao termo original utilizado por Vigotski na língua russa é zona de desenvolvimento iminente, "pois sua característica essencial é a das possibilidades de desenvolvimento, mais do que do imediatismo e da obrigatoriedade da ocorrência $[\ldots] "$. 
De forma complementar, a Teoria da Atividade - desenvolvida por Leontiev, a partir dos estudos de Vigotski (PRESTES, 2012; ALQUETE et al., 2013) - compreende a atividade como ação que faz a mediação entre sujeito e objetos, a partir das relações sociais e do contexto sociocultural (LIBÂNEO; FREITAS, 2006). Assim, os elementos do sistema (ação, objeto, sujeito) têm influência sobre os outros. Alquete et al. (2013) destacam que as tecnologias digitais podem ser consideradas, com base na Teoria da Atividade, como artefatos de mediação entre os usuários e o mundo - ou, no caso de atividades de estudo, mediação da aprendizagem. Neste caso, conforme a Teoria da Atividade, as relações entre indivíduos de um sistema influenciam o uso de ferramentas digitais, as quais interferem nas atividades. Timmis (2012) salienta que o modo como as tarefas e funções colaborativas são divididas pode ter influência sobre a maneira como os colegas trabalham juntos.

A interação social é também a base do conceito de cognição distribuída (HUTCHINS, 2001), segundo o qual os processos cognitivos são passíveis de distribuição entre membros de um grupo social (para além das capacidades individuais), de forma coordenada e ao longo do tempo, em contextualização com os aspectos socioculturais. Hutchins (2001) ressalta que as interações entre os indivíduos podem gerar fenômenos não previsíveis a partir da ação isolada de um indivíduo. Tais fenômenos, por sua vez, podem ser incorporados à cultura e tornarse disponíveis para apropriação pelos demais.

Dentro dessa visão, a cognição é inseparável da interação e da ação com o mundo, atuando de forma contextualizada e concreta. A partir disso, é possível constatar que ela se beneficia da interação entre humanos e não humanos. Ou seja, ela trata da ideia de que a produção de conhecimento não está centrada em um único indivíduo, mas na interação entre indivíduos e ferramentas presentes no ambiente em que ele vive e que auxiliam na produção de conhecimentos de forma colaborativa. Portanto, pode-se dizer que compartilhar e colaborar auxiliam tanto no desenvolvimento cognitivo quanto no cultural. (REGIS; TIMPONI; MAIA, 2012, pp. 128-129)

O compartilhamento de informações via redes sociais ou aplicativos de mensagens instantâneas e a elaboração conjunta de trabalhos em arquivos armazenados virtualmente, por exemplo, são hoje atividades comuns no cotidiano 
de jovens e adultos, que podem se constituir como práticas de cognição distribuída. No âmbito da Educação, a colaboração entre estudantes na realização de exercícios ou trabalhos permite uma distribuição mais ampla de processos cognitivos (BANNELL, 2017). Ou seja, admite-se que a cognição não acontece no sujeito, mas está distribuída no coletivo.

Duas cabeças juntas pensam melhor do que uma, como se diz, mas múltiplas cabeças pensam ainda melhor, especialmente quando estão conectadas por meio de artefatos tecnológicos e, consequentemente, capazes de operar a vastas distâncias e com habilidades operacionais expandidas. (BANNELL, 2017, pp.1718).

\section{2.}

\section{O campo empírico: alguns achados}

A comparação entre uma situação local e outras já estudadas integra o processo de produção de conhecimento e sua interpretação (VAN ZANTEN, 2004). No intuito de compreender o que outros estudos apontam sobre as questões apresentadas para esta pesquisa, realizou-se uma busca nas bases de dados SciELO (Scientific Electronic Library Online), Scopus, Portal de Periódicos e Banco de Teses e Dissertações da Capes, além do Google Acadêmico, utilizando a conjugação dos termos "tecnologia", "modos de uso do celular", "dispositivos móveis de comunicação", "aprendizagem móvel”, "ensino superior", "universidade", "universitários", em português e em inglês. A intenção foi reunir artigos, dissertações, teses, resumos, entre outros, elaborados no Brasil e no exterior, que reflitam sobre os usos de tecnologias móveis, em especial o celular, por estudantes universitários. A revisão empírica buscou pesquisas a respeito desses usos em iniciativas dos próprios estudantes, realizadas de forma mais autônoma, ou seja, desvinculadas da proposta de determinada disciplina ou de algum professor, com foco nas percepções dos alunos acerca do modo como utilizam e se relacionam com os dispositivos. Alguns dos estudos estão detalhados a seguir.

As relações que estudantes de graduação têm com as tecnologias da informação são objeto de ampla investigação, de caráter longitudinal, realizada desde 2004 pela associação norte-americana Educause Center for Analysis and 
Research. O relatório de 2015 teve como base cerca de 50 mil respostas, de estudantes de 11 países e 43 estados norte-americanos. Entre as principais conclusões está a percepção de que a tecnologia está incorporada no cotidiano dos estudantes, que se sentem preparados a utilizá-las e que possuem, mais que em qualquer outro momento, dispositivos pessoais com possibilidade de acesso à internet. No entanto, o estudo aponta que, embora haja um elevado nível de interesse no uso de dispositivos móveis para melhorar a aprendizagem, sua utilização real com esse propósito permanece baixa (BROOKS, 2015).

Gikas e Grant (2013) analisaram a perspectiva de universitários dos Estados Unidos sobre aprendizagem com o uso de dispositivos móveis portáteis no ensino superior. A partir da questão "Quais são as experiências dos estudantes quando dispositivos de computação móvel são integrados a cursos de educação superior?”, a produção de dados se deu em abordagem qualitativa (entrevistas em grupos focais), com nove estudantes de três universidades norte-americanas - Faculdade Coastal, Universidade Lakeshore e Universidade de Northbook.

Entre as vantagens apontadas pelos estudantes acerca da aprendizagem com os dispositivos móveis destacam-se o acesso rápido às informações, a maior capacidade de comunicação e colaboração com os colegas e com o professor, a variedade de modos para aprender (vídeos, áudios, blogs, e-mail) e a possibilidade de aprendizagem situada, em contexto específico e particular, relacionado ao cotidiano dos estudantes. Com relação às frustrações, os estudantes salientaram a postura "antitecnologia" dos professores, os desafios técnicos - aplicativos que não funcionam ou tamanho reduzido dos dispositivos - e a distração provocada pelos aparelhos. Apesar das limitações identificadas, os participantes do estudo reconheceram mudanças positivas na aprendizagem.

Quanto aos modos de uso dos dispositivos móveis para aprendizagem, Gikas e Grant identificaram: participação em fóruns de discussão; leitura de conteúdos; visualização de vídeos em sala de aula; postagem de conteúdo nos sites do curso; acesso ao material do curso via e-mail; troca de mensagens de texto e emails; postagem em redes sociais; gravação de vídeos ou mensagens de voz; publicação em blog. A utilização desses dispositivos em atividades similares foi apontada na dissertação de Carvalho (2012), sobre as expectativas de estudantes adultos do ensino superior a distância da Universidade Aberta de Portugal quanto ao uso dos celulares, tablets e afins para aprendizagem. Os participantes da pesquisa 
consideraram como principais potencialidades para utilização dos dispositivos em práticas de estudo online a possibilidade de "receber avisos sobre o início ou fim das atividades" e de "acessar conteúdos em qualquer lugar e a qualquer hora" (CARVALHO, 2012, pp.108-109). O principal impedimento apontado foi o preço dos aparelhos e das tarifas cobradas pelas operadoras de telefonia.

A receptividade e a predisposição de estudantes e docentes para o uso de dispositivos móveis no ensino superior foram tema de investigação desenvolvida por Sousa (2014) no Instituto Politécnico do Porto, Portugal. A facilidade e rapidez no acesso à informação e a mobilidade foram apontados por professores e alunos como principais benefícios da utilização dos dispositivos para a aprendizagem. No que se refere às desvantagens, as limitações técnicas dos aparelhos (tela pequena, duração da bateria, entre outros) foram destacadas pelos dois grupos. Os estudantes apontaram, em seguida, as limitações de conteúdo e softwares, enquanto os professores indicaram a possibilidade de dificultar a concentração dos alunos. Para os participantes da pesquisa, os dispositivos móveis poderiam ser utilizados na aprendizagem principalmente para consultas, trocas e partilha de informação, para o trabalho colaborativo e para esclarecimento de dúvidas em tempo real.

[...] concluiu-se que, na sua maioria, os docentes e estudantes estão predispostos e receptivos à utilização de dispositivos móveis em contexto de ensino e aprendizagem, por considerarem que este tipo de aparelhos poderá proporcionar a criação de ferramentas pedagógicas úteis, aumentando a motivação dos alunos e o trabalho colaborativo e, sobretudo, pela mobilidade e portabilidade que este tipo de aparelhos pode oferecer, podendo os utilizadores usarem os dispositivos móveis em qualquer lugar e a qualquer momento. (SOUSA, 2014, p. 92).

Algumas pesquisas relatam experiências de estudantes universitários com o uso de celulares para fins de aprendizagem em cursos de áreas específicas do conhecimento. A utilização de dispositivos móveis em atividades de estudo por alunos de cursos de Medicina foi abordada por Chang et al. (2012), Masika et al. (2015), Briz-Ponce e Juanes-Méndes (2015). Essas investigações apontam para a utilização de aplicativos específicos da área médica pelos estudantes de universidades de Botswana, do Quênia e da Espanha, ainda que com diferenças no percentual de uso - maior entre os estudantes das instituições africanas do que os da universidade espanhola. Já Dourado (2015) investigou em sua dissertação a 
percepção de estudantes do curso de Psicologia de uma instituição de ensino superior privada de Brasília (DF) sobre as potencialidades e fragilidades do uso do celular para a aprendizagem no contexto escolar. O estudo apontou que os jovens fazem utilização constante do aparelho em sala de aula, admitindo o uso para pesquisar, resolver questões, trocar impressões e debater com os colegas.

Por sua vez, Dukic, Chiu e Lo (2015) realizaram investigação com estudantes de duas universidades, uma de Hong Kong e outra do Japão, dos cursos de Biblioteconomia e Ciência da Informação. Os pesquisadores produziram os dados a partir de grupos focais on-line, numa página criada no Facebook para este fim. O grupo na rede social era composto por 65 membros, estudantes de graduação e pós-graduação das duas universidades, em matriculados nos anos de 2013/2014. Os resultados tiveram como base as respostas de 20 alunos que participaram mais ativamente das discussões, a partir das seguintes perguntas: 1) Que tipos de dispositivos móveis você possui e usa?; 2) Para quais fins você utiliza seu celular?; 3) Você usa o celular para fins de aprendizagem? Como? Que tipo de atividades você realiza para estes fins?; 4) Você usa o celular para acessar a biblioteca da universidade? Quais serviços você usa?. A análise dos dados organizou os resultados em três eixos na definição de três categorias analíticas: tipo de dispositivo móvel que os alunos possuem e usam; uso de smartphones para comunicação, entretenimento e necessidades diárias de informação; uso de smartphones para aprender e estudar.

No que se refere à utilização para fins de estudo, Dukic, Chiu e Lo identificaram, entre outros pontos, que os estudantes não consideram o celular um meio adequado para leitura de textos acadêmicos ou para a produção de trabalhos escritos, principalmente devido ao tamanho reduzido da tela. Alguns participantes da pesquisa destacaram também que o estudo requer concentração e um ambiente mais calmo, como biblioteca, escritório ou casa, e que nesses casos preferem o computador. Nesse sentido, os autores inferem que os celulares são utilizados mais fora de casa e do trabalho, ambientes menos adequados para a aprendizagem. Eles sugerem ainda que, embora sejam raramente usados para leitura ou produção acadêmica, os celulares são utilizados em atividades relacionadas à aprendizagem, como discussões sobre trabalhos e outros tópicos, com colegas de classe, em redes sociais e aplicativos de mensagem instantânea. Os estudantes mencionaram utilizar o aparelho também para verificar notas, acessar plataformas de aprendizagem do 
curso, verificar e-mails e gravar entrevistas. Uso de calendário, lista de tarefas e aplicações que atendam a necessidades individuais, como dicionários, tradutores e tutoriais, também foram apontados pelos universitários de Hong Kong e do Japão.

Ferreira (2015) analisou o uso de smartphones por alunos do curso de Licenciatura em Pedagogia da Universidade Federal de Pernambuco. O estudo seguiu uma abordagem qualitativa, que incluiu a aplicação de questionário para mapeamento de uso e acesso a dispositivos móveis e a realização de entrevistas semiestruturadas, com o objetivo de compreender as relações dos estudantes com esses aparelhos. A intencionalidade da autora vai ao encontro da proposta desta pesquisa no que se refere à autonomia dos alunos no processo de estudo e aprendizagem:

"[...] o interesse foi entender como a inserção dos dispositivos móveis (sendo estes os smartphones) na sociedade tem atingido o comportamento de aprender dos alunos, sem um direcionamento institucional. Queremos compreender se os estudantes utilizam os celulares para a sua própria aprendizagem, em quais contextos, para que, na ótica da Aprendizagem móvel ou mobile learning." (FERREIRA, 2015, p. 13)

A primeira fase do estudo de Ferreira, de mapeamento mais geral, contou com 56 sujeitos, que ofereceram respostas válidas aos questionários. Na segunda fase, sobre as estratégias de uso dos smartphones, foram selecionados seis sujeitos, que demonstraram uso intenso dos dispositivos para fins acadêmicos e disponibilidade para participar das entrevistas. Para a análise de dados, a autora criou três unidades temáticas a partir do conteúdo das entrevistas: uso da internet no smartphone; ações com o smartphone; smartphone e suas ferramentas. Os resultados indicaram as seguintes categorias de ações dos estudantes: pesquisa, leitura, registro, estudo e troca de informações da aula.

A autora ressaltou que o conceito de mobilidade se aplica aos dados obtidos nas conversas com os participantes: "Da mesma maneira que nossos sujeitos aproveitam os deslocamentos para estudar, utilizam-se de tempos fracionados para isto também." (FERREIRA, 2015, p. 86). Outro aspecto destacado foi a colaboração entre os colegas de turma, por meio da troca de informações e do compartilhamento de conteúdo via dispositivos móveis. 
Em pesquisa com 388 universitários do curso de Pedagogia da Universidade Nacional de Educação a Distância da Espanha, Vásquez-Cano (2014) buscou determinar se os celulares têm impacto positivo no aprendizado acadêmico, por meio da avaliação das opiniões e experiências dos estudantes com o uso desses dispositivos. De acordo com os resultados, os universitários percebem o celular como elemento facilitador do processo de ensino e como um recurso útil no processo de aprendizagem, especialmente por possibilitar o desenvolvimento dos temas e promover o trabalho colaborativo.

Longe de aumentar o isolamento, o aprendizado móvel permite que os indivíduos tenham mais oportunidades de cultivar as habilidades complexas necessárias para trabalhar produtivamente com os outros. Smartphones e aplicativos podem ajudar os alunos a fazer e responder perguntas, concluir projetos colaborativos e, de maneira mais geral, engajar-se nas interações sociais fundamentais para o aprendizado. (VÁSQUEZ-CANO, 2014, p. 1.516, tradução da autora)

No que se refere às interações mediadas pelas tecnologias digitais, Brckalorenz et al. (2013) analisaram os resultados da edição 2012 da Pesquisa Nacional de Engajamento Estudantil (NSSE, na sigla em inglês), realizada nos Estados Unidos, e encontraram relações positivas entre a frequência de uso de tecnologia para comunicação e percepções dos estudantes sobre a qualidade de suas interações pessoais. De acordo com os autores, os estudantes que mais utilizavam a tecnologia como ferramenta de comunicação tinham relacionamentos mais positivos com seus colegas de classe. A pesquisa também identificou relações positivas entre o uso da tecnologia e os ganhos percebidos pelos alunos em situações como trabalhar em grupo; resolver problemas complexos do mundo real; escrever e falar de forma clara e eficaz; e pensar crítica e analiticamente.

Foti e Mendez (2014), em pesquisa com estudantes de mestrado em Terapia Ocupacional dos Estados Unidos, observaram que os dispositivos móveis são o meio preferido para o compartilhamento de informações e a colaboração dentro e fora de sala de aula. Farley et al. (2015) destacam que estudantes da Universidade do Sul de Queensland, na Austrália, utilizam ativamente dispositivos móveis para apoiar seu aprendizado, mas ainda esbarram nas limitações técnicas dos sistemas universitários e a resistência por parte dos professores. 
Sobre o uso específico de aplicativos de mensagens instantâneas, Timmis (2012) observou, em pesquisa desenvolvida com universitários do Reino Unido, que algumas trocas de mensagens entre os estudantes permitiram-lhes desenvolver um entendimento compartilhado, estabelecer e reconhecer um problema, além de sugerir modos de ajuda a seus colegas. Kaieski, Grings e Fetter (2015) analisaram iniciativas de uso do WhatsApp em atividades pedagógicas e desenvolveram uma pesquisa-ação em duas instituições de ensino (escola de idiomas e escola técnica). Obtiveram avaliação geral positiva tanto de discentes como docentes, sobretudo no que se refere à facilidade de resolução de dúvidas por meio do aplicativo.

Estes foram alguns dos achados empíricos utilizados como elementos para refletir sobre as questões propostas a esta pesquisa e para propor diálogos entre os resultados. O próximo capítulo apresenta os procedimentos metodológicos adotados para seu desenvolvimento e os detalhes do trabalho de campo. 


\title{
3
}

\section{Os caminhos da pesquisa}

\section{1.}

\section{Instrumentos para produção e análise dos dados}

Para identificar os modos de uso do celular para estudo e compreender as motivações e as percepções dos estudantes quanto aos resultados obtidos com o uso do aparelho, bem como apontar diferenças de uso por alunos de cursos de áreas distintas, verificou-se a necessidade de detalhamento da relação que os estudantes mantêm com seus dispositivos. Nesse sentido, a pesquisa assumiu um caráter qualitativo e o instrumento escolhido para nortear a produção de dados foi a entrevista semiestruturada, que utiliza um roteiro pré-estabelecido mas permite que o entrevistador modifique ou inclua perguntas a partir das reflexões dos participantes (OLIVEIRA; FONSECA; SANTOS, 2010). Este tipo de entrevista assegura a obtenção de informações com mais flexibilidade (LÜDKE; ANDRÉ, 1986) e maior profundidade do que um instrumento com questões fechadas (ZAGO, 2011).

As entrevistas permitem, segundo Duarte (2004), reunir indícios dos modos como os participantes da pesquisa se relacionam com a realidade, o que vai ao encontro dos objetivos deste estudo.

\begin{abstract}
Entrevistas são fundamentais quando se precisa/deseja mapear práticas, crenças, valores e sistemas classificatórios de universos sociais específicos, mais ou menos bem delimitados, em que os conflitos e contradições não estejam claramente explicitados. Nesse caso, se forem bem realizadas, elas permitirão ao pesquisador fazer uma espécie de mergulho em profundidade, coletando indícios dos modos como cada um daqueles sujeitos percebe e significa sua realidade e levantando informações consistentes que lhe permitam descrever e compreender a lógica que preside as relações que se estabelecem no interior daquele grupo, o que, em geral, é mais difícil de se obter com outros instrumentos de coleta de dados. (DUARTE, 2004, p. 215)
\end{abstract}

Optou-se por realizar entrevistas presenciais, uma vez que a interação face a face permite que o entrevistado descreva fatos e narrativas de seu cotidiano de forma mais personalizada (OLIVEIRA; FONSECA; SANTOS, 2010). O protocolo 
de entrevista ${ }^{4}$ foi elaborado com base nos objetivos propostos para a pesquisa. A construção do roteiro seguiu, conforme preconizam Lüdke e André (1986), uma sequência lógica nos assuntos, partindo dos temas e questionamentos mais gerais para aqueles mais complexos e específicos, que demandam detalhamento.

No que se refere à produção e à análise dos dados, as entrevistas foram audiogravadas e transcritas pela pesquisadora. O conteúdo foi organizado e categorizado com o auxílio do software de análise qualitativa de dados ATLAS.ti, a partir da criação de códigos e categorias para organização e comparação dos dados, conforme detalhado no item 3.5. A metodologia desta fase da pesquisa teve como base a análise de conteúdo, no sentido de buscar significados nas falas dos entrevistados, com aponta Franco (2012):

[...] a análise de conteúdo é um procedimento de pesquisa que se situa em um delineamento mais amplo da teoria da comunicação e tem como ponto de partida a mensagem. Com base na mensagem que responde às perguntas: o que se fala? o que se escreve? com que intensidade? com que frequência? que tipo de símbolos figurativos são utilizados para expressar ideias? e os silêncios? e as entrelinhas?... e assim por diante, a análise de conteúdo permite ao pesquisador fazer inferências sobre qualquer um dos elementos da comunicação. (FRANCO, 2012, pp. 25-26)

Independentemente do tipo de abordagem metodológica adotada e dos instrumentos escolhidos para produção e análise de dados, um aspecto fundamental deve perpassar as pesquisas em todos os campos do conhecimento: o cuidado ético, em especial nos estudos que envolvem seres humanos. "O respeito à pessoaparticipante da pesquisa envolve aproximação cautelosa, relação afetuosa, interação sigilosa." (TEIXEIRA; OLIVEIRA, 2010, p. 9).

A normativa que regulamenta a pesquisa com seres humanos no Brasil solicita que, antes do início do trabalho de campo, sejam apresentados a um comitê de ética o projeto de pesquisa e o Termo de Consentimento Livre e Esclarecido (TCLE), com informações que ofereçam subsídios aos participantes para compreender os objetivos, procedimentos, possíveis riscos e benefícios esperados da pesquisa (TEIXEIRA; OLIVEIRA, 2010). Assim, um dos primeiros passos desta

\footnotetext{
${ }^{4}$ O protocolo de entrevista está disponível no Apêndice A.
} 
pesquisa foi submeter o projeto e o TCLE 5 ao Comitê de Ética em Pesquisa da PUCRio, que emitiu parecer favorável.

É importante pontuar que, ao longo do trabalho de campo, busquei me cercar de cuidados éticos em todas as etapas deste estudo, sobretudo no contato inicial com professores e estudantes, nas visitas às turmas, na abordagem individual para marcação dos encontros e durante as conversas com os participantes da pesquisa. Embora a realização de entrevistas seja parte de minha rotina como profissional do jornalismo, a todo momento estive atenta às especificidades da entrevista como instrumento de produção de dados na pesquisa científica.

\section{2.}

\section{A determinação do campo}

Uma vez definido que o estudo teria foco na perspectiva de estudantes de graduação, optou-se por realizar a pesquisa na Universidade Federal do Estado do Rio de Janeiro (Unirio), onde trabalho como jornalista, lotada na Coordenadoria de Comunicação Social. Por atuar em âmbito mais institucional, sem contato direto com o cotidiano dos discentes da instituição, foi particularmente interessante ter a possibilidade de me aproximar desse segmento da comunidade universitária e compreender algumas dinâmicas relacionadas a sua rotina acadêmica.

Criada em 5 de junho de 1979, a Unirio tem origem na Federação das Escolas Isoladas do Estado da Guanabara (Fefieg), que em 1969 reuniu estabelecimentos isolados de ensino superior, anteriormente vinculados aos ministérios do Trabalho, do Comércio e da Indústria; da Saúde; e da Educação e Cultura. A instituição oferece 35 cursos de graduação, entre bacharelados e licenciaturas, além de cursos de pós-graduação lato e stricto sensu e de extensão.

A universidade estrutura-se em cinco grandes unidades acadêmicas: Centro de Ciências Biológicas e da Saúde (CCBS); Centro de Ciências Exatas e Tecnologia (CCET); Centro de Ciências Humanas e Sociais (CCH); Centro de Ciências Jurídicas e Políticas (CCJP); e Centro de Letras e Artes (CLA). A oferta de cursos

5 O Termo de Consentimento Livre e Esclarecido apresentado aos participantes da pesquisa está disponível no Apêndice B. 
de graduação nas áreas das Ciências Exatas e das Humanidades possibilitou a produção de dados para atender a um dos objetivos específicos da pesquisa: Identificar semelhanças e diferenças de usos e de visões dos estudantes relacionadas às distintas áreas de conhecimento dos cursos aos quais estão vinculados.

\section{3.}

\section{O percurso do campo}

Sobre a definição e a delimitação dos sujeitos da investigação, Zago (2011) destaca que nas pesquisas qualitativas a amostra não será representativa e, portanto, é preciso refletir sobre o critério de seleção dos participantes. Para este estudo, optou-se por entrevistar estudantes de cursos de graduação presencial da Unirio, contemplando dois centros acadêmicos da universidade: Centro de Ciências Exatas e Tecnologia (CCET) e Centro de Ciências Humanas e Sociais (CCH). Uma das hipóteses trabalhadas foi de que poderiam existir diferenças no uso de tecnologias digitais em atividades acadêmicas entre estudantes cuja formação profissional envolve o domínio dessas tecnologias em comparação a estudantes da área das humanidades, para os quais esse domínio não é exigido, como aponta González (2015).

Definidas as unidades acadêmicas, partiu-se para a seleção dos cursos. No caso do CCET, foram convidados a participar da pesquisa alunos dos três cursos que integram o centro: Bacharelado em Engenharia de Produção, Bacharelado em Sistemas de Informação e Licenciatura em Matemática. De forma equivalente, foram também convidados alunos de três cursos do $\mathrm{CCH}$, selecionados de acordo com a modalidade e o turno, em similaridade com os cursos das Ciências Exatas. A intenção foi aproximar a rotina acadêmica dos estudantes entrevistados, para que houvesse alguma similaridade nos horários em que eles estão dentro e fora da universidade. Com base nesse critério, os cursos do $\mathrm{CCH}$ escolhidos foram: Bacharelado em Museologia, ministrado em turno noturno, e Bacharelado em Filosofia, ministrado nos turnos vespertino e noturno. Já o curso de licenciatura noturno investigado foi Pedagogia, selecionado por ser o espaço de formação de 
professores e, portanto, suscitar interesse específico para o campo da Educação, no qual esta pesquisa se insere.

O procedimento seguinte foi solicitar autorização dos coordenadores dos cursos para visitação das turmas dos cursos selecionados, a fim de convidar os estudantes a participarem da pesquisa. Um critério adotado para agendar as visitas foi a escolha de disciplinas de meio de curso ( $3^{\circ}$ a $6^{\circ}$ períodos). Isto porque no primeiro ano da graduação os estudantes, em sua maioria, estão em fase de adaptação ao contexto universitário e têm menos autonomia para realizar suas atividades de estudo; por outro lado, alunos dos últimos períodos tendem a estar mais envolvidos com atividades externas, como estágios, ou mais preocupados com a elaboração dos trabalhos finais, o que poderia dificultar a adesão à pesquisa. No entanto, ao longo das visitas em salas de aula e nos contatos posteriores com os estudantes, observou-se que as turmas de cada disciplina agrupam graduandos de vários períodos, uma vez que os estudantes nem sempre seguem de modo estrito o fluxograma de disciplinas recomendado pelos cursos para cada semestre.

A partir da grade curricular de cada um dos cursos, foram contatados os professores para solicitação de autorização e marcação das visitas. A primeira fase de visitação ocorreu nos meses de agosto e setembro de 2017.

As visitas aconteceram no início (na maioria dos casos), nos intervalos ou ao final das aulas, conforme as indicações dos docentes sobre o período mais indicado para contato com os estudantes. A cada visitação, após breve explicação da pesquisa, solicitou-se aos alunos interessados em participar que preenchessem formulário com nome, e-mail e número do celular para marcação das entrevistas.

Como resultado da primeira fase de visitas, 59 estudantes dos seis cursos manifestaram interesse em participar da pesquisa e informaram seus contatos. A proposta inicial era entrevistar quatro alunos de cada um dos cursos - iniciando a produção de dados a partir de 24 entrevistas - e a partir daí, caso necessário, incorporar outros participantes na medida em que surgissem voluntários. O retorno ao contato para a marcação das entrevistas, no entanto, não foi suficiente para atender ao número previsto inicialmente. Dos 59 estudantes que manifestaram interesse, apenas 11 tiveram disponibilidade para efetivamente participar da pesquisa e marcar um horário para entrevista - a maioria não deu retorno às tentativas de contato da pesquisadora via e-mail, mensagens e ligações pelo celular. 
Decidiu-se então por uma segunda fase de visitas às turmas, realizada entre o fim de novembro e o início de dezembro de 2017. No entanto, a visitação foi dificultada pela proximidade do fim do semestre letivo; algumas turmas estavam em período de provas ou de apresentação de trabalhos, outras já tinham encerrado suas atividades e o número de estudantes na universidade estava reduzido. Ainda assim, as visitas resultaram em novos 14 voluntários, dos quais nove (9) retornaram o contato e se disponibilizaram para as entrevistas.

A pesquisa contou, portanto, com um total de 20 entrevistados - ou seja, todos os estudantes que se dispuseram a participar do estudo, 12 das Ciências Exatas e oito (8) das Ciências Humanas. A intenção inicial era de que a proporção de entrevistados fosse equivalente (seis estudantes por curso). No entanto, devido às dificuldades para conseguir adesões para as entrevistas e já que não foi possível atingir o total pretendido de 24 participantes, optou-se por considerar todas as entrevistas realizadas para a análise e produção de dados. Embora não seja possível afirmar, uma vez que não foi realizada uma investigação específica sobre essa questão, a maior adesão dos estudantes dos cursos das Ciências Exatas - em especial da Engenharia de Produção - pode sugerir um interesse maior destes alunos pelo tema abordado na pesquisa.

Os estudantes indicaram os locais e horários de preferência para as entrevistas. A maior parte delas realizou-se em espaços da Unirio: salas de aula não ocupadas no horário da conversa; corredores e pátios das unidades acadêmicas; sala de convivência da Biblioteca Central. Uma das entrevistas aconteceu num shopping center próximo à residência do estudante; outra, no local de trabalho do entrevistado.

Antes do início de cada conversa, os estudantes receberam o Termo de Consentimento Livre e Esclarecido - TCLE (Apêndice B), em que constavam as seguintes informações: nome e contatos das pesquisadoras envolvidas no estudo (mestranda e orientadora); justificativa da pesquisa; objetivos; metodologia; riscos e benefícios. Os termos foram lidos pelos estudantes e, após esclarecimento de dúvidas e questionamentos, quando houve, assinados em duas vias - uma entregue ao entrevistado e outra arquivada pela pesquisadora.

As entrevistas tiveram duração média de 37 minutos e foram todas audiogravadas, mediante concordância dos estudantes, conforme previsto no TCLE. Em alguns casos, solicitou-se que os entrevistados fizessem uma captura da 
tela do celular (print screen), para registrar determinada imagem ilustrativa do uso do dispositivo em atividade de estudo. Algumas dessas imagens foram utilizadas na fase de análise e produção de dados, e constam do Capítulo 4. No caso de um estudante que mencionou o uso do celular para elaboração de trabalhos acadêmicos, com a utilização de um miniteclado, realizou-se uma gravação em vídeo, também para fins de análise e produção de dados.

\section{4}

\section{Perfil dos participantes}

Do total de entrevistados, nove são do sexo feminino e 11 do sexo masculino $^{6}$. Entre os estudantes das Ciências Exatas, há predominância de estudantes do sexo masculino (oito), em comparação às estudantes do sexo feminino (quatro). No caso dos entrevistados das Humanidades, a distribuição se inverte: cinco são do sexo feminino e três, do sexo masculino.

As idades dos estudantes variam entre 18 e 33 anos, e a média geral ficou em 22,8 anos. Houve uma pequena diferença na média de idade entre os campos do conhecimento: 21,6 anos para os estudantes das Exatas e 24,5 anos para aqueles da área de Humanas. Nasceram, portanto, a partir da década de 1980 e "cresceram cercados de diferentes tecnologias digitais que continuam a moldar o modo como vivem, pensam, aprendem e interagem" (MOURA, 2010, p. 137).

Prensky (2001, p.1, tradução da autora) cunhou o termo nativos digitais para se referir aos integrantes das primeiras gerações que nasceram e cresceram na era digital e são, portanto, “'falantes nativos' da linguagem digital dos computadores, dos videogames e da internet". Os nativos digitais pensam e processam informações

6 Não foi objetivo desta pesquisa analisar diferenças entre os gêneros e, portanto, não houve comparação entre as percepções de estudantes do sexo masculino e do sexo feminino. Para facilitar a leitura, optou-se por adotar nesta dissertação o masculino genérico, ou seja, o grupo de estudantes de ambos os sexos é referido como "os estudantes", no masculino (idem para "os entrevistados", "os jovens" e demais referências), à exceção de trechos transcritos das entrevistas, em que foram mantidas as concordâncias de gênero nas autorreferências. Entretanto, cabe ressaltar que há discussões sobre linguagem inclusiva de gênero, tais como as produções de Caldas-Coulthard (2007), Guerra (2014) e Mäder (2015), entre outras. 
de modo distinto dos imigrantes digitais, que não nasceram no mundo digital mas utilizam as tecnologias em seu cotidiano ${ }^{7}$.

Os nativos digitais estão acostumados a receber informações muito rapidamente. Eles gostam de processo paralelo e multitarefa. Eles preferem seus gráficos antes do texto e não o contrário. Eles preferem acesso aleatório (como hipertexto). Eles funcionam melhor quando estão em rede. Eles prosperam com gratificação instantânea e recompensas frequentes. Eles preferem jogos ao trabalho "sério". (PRENSKY, 2001, p. 2, tradução da autora).

Moura (2010) elenca outros termos que se referem, de modo similar, aos indivíduos de acordo com sua inserção no mundo digital desde o nascimento ou a infância: geração Net (ou -N), geração millennium (ou millennials), geração móvel. O uso cotidiano da tecnologia, a habilidade multitarefa, a conectividade constante, o imediatismo, a habilidade multimídia, a sociabilidade e o espírito de equipe são algumas das características comuns às novas gerações (REDECKER, 2009, apud MOURA, 2010) e que podem influenciar os processos de estudo e aprendizagem. A considerar pela média das idades, os participantes desta pesquisa se enquadram nos perfis traçados para as novas gerações.

7 Os conceitos de nativos digitais e imigrantes digitais evoluíram para a proposição de Prensky (2009) dos sábios digitais, aqueles que utilizam a tecnologia a seu favor, para melhorar suas próprias capacidades. 
Quadro 1 - Perfil dos participantes da pesquisa

\begin{tabular}{|c|c|c|c|c|}
\hline Curso & Distribuição & $\begin{array}{c}\text { Médias das } \\
\text { idades (anos) }\end{array}$ & \multicolumn{2}{|c|}{ Gênero } \\
\hline $\begin{array}{c}\text { Bacharelado em } \\
\text { Engenharia de Produção }\end{array}$ & 5 & 23 & 2 & 3 \\
\hline $\begin{array}{c}\text { Bacharelado em } \\
\text { Sistemas de Informação }\end{array}$ & 4 & 19,5 & 1 & 3 \\
\hline $\begin{array}{c}\text { Licenciatura em } \\
\text { Matemática }\end{array}$ & 3 & 22,3 & 1 & 2 \\
\hline $\begin{array}{c}\text { Bacharelado em } \\
\text { Filosofia }\end{array}$ & 4 & 21,25 & 3 & 1 \\
\hline $\begin{array}{c}\text { Bacharelado em } \\
\text { Museologia }\end{array}$ & 1 & 27 & 1 & - \\
\hline $\begin{array}{c}\text { Licenciatura em } \\
\text { Pedagogia }\end{array}$ & 3 & 28 & 1 & 2 \\
\hline
\end{tabular}

Fonte: Elaborado pela autora com dados da pesquisa.

\section{5}

\section{Categorias de análise}

O procedimento de análise de conteúdo requer uma fase inicial de préanálise, que corresponde a "um conjunto de buscas iniciais, de intuições, de primeiro contato com os materiais" (FRANCO, 2012, p. 53). Nesta dissertação, a fase de pré-análise teve início com as transcrições das entrevistas, feitas pela própria pesquisadora, que durante este processo registrou comentários sobre passagens consideradas relevantes para a produção de dados. O passo seguinte, já com o uso do ATLAS.ti, foi proceder uma leitura flutuante das entrevistas transcritas, selecionar as citações e atribuir ao conteúdo manifesto os primeiros códigos para a análise. Ao fim desta etapa, foram criados 42 códigos preliminares, sobre temas relacionados diretamente aos objetivos da pesquisa (usos do celular, ganhos, Exatas, Humanas) e outros que se destacaram pela recorrência (como WhatsApp, mobilidade, computador $\mathrm{x}$ celular) ou que indicaram possibilidades de aprofundamento do tema (leitura no celular, atuação dos professores, atenção).

Com o objetivo de testar o processo de codificação, encaminhou-se uma das entrevistas, escolhida aleatoriamente, a duas integrantes do Grupo de Pesquisa Educação e Mídia (Grupem/PUC-Rio) - do qual faz parte a autora deste estudo -, 
juntamente com a lista de códigos e uma breve definição de cada um deles. $\mathrm{Na}$ entrevista estavam destacadas todas as citações previamente codificadas pela pesquisadora e frequência de códigos atribuídos a cada citação (no caso da entrevista teste, cada citação recebeu de um a três códigos). Solicitou-se, então, que as integrantes do Grupem atribuíssem códigos às citações destacadas, para posterior comparação dos resultados com a codificação original. A intenção foi testar se havia clareza nas definições de cada um dos códigos atribuídos.

Foram contabilizadas as concordâncias e não concordâncias, com os seguintes resultados:

- Integrante 1: 51 concordâncias e 15 não concordâncias, para o total de 66 codificações $^{8}$ (77\% de concordância);

- Integrante 2: 47 concordâncias e 20 não concordâncias, para o total de 67 codificações (70\% de concordância).

Para Bauer (2013), a concordância entre intérpretes, representada pela fidedignidade, deve ser considerada para melhoria do processo de codificação previsto na análise de conteúdo. O autor preconiza que "a fidedignidade é geralmente considerada muito alta quando $r>0.90$, alta quando $r>0.80$, e aceitável na amplitude $0.66<\mathrm{r}>0.79$ " (BAUER, 2013, p. 207).

Com base nesta escala, os resultados obtidos na validação de fidedignidade do processo de codificação ( 0.77 para a integrante 1 e 0.70 para a integrante 2$)$ foram considerados aceitáveis. As respostas discordantes (códigos diferentes atribuídos para uma mesma citação) foram consideradas pela pesquisadora para refinar algumas codificações. Alguns códigos foram mesclados e outros foram criados para abarcar o que emergiu de uma análise mais aprofundada das entrevistas.

Ao fim do processo de codificação, chegou-se ao total de 40 códigos ${ }^{9}$, além do grupo de códigos 'Aplicativos', que embasaram a criação de categorias de análise. Além disso, os documentos foram divididos em dois grupos, 'Exatas' e 'Humanas', para facilitar a comparação entre as entrevistas dos estudantes de cada uma das áreas do conhecimento.

\footnotetext{
${ }^{8}$ A integrante 1 deixou de atribuir um código a uma das citações.

9 A relação de códigos e do grupo de códigos ‘Aplicativos' está disponível no Apêndice C.
} 
A categorização é, conforme Bardin (2009, p.145), "uma operação de classificação de elementos constitutivos de um conjunto por diferenciação e, seguidamente, por reagrupamento segundo o género (analogia), com os critérios previamente definidos". Na análise desenvolvida neste estudo, seis categorias foram estabelecidas a partir de unidades temáticas relacionadas aos objetivos da pesquisa e dos temas que surgiram espontaneamente dos relatos. São elas: Usos do celular em atividades de estudo; Motivações para o uso; Percepções para o uso; Atenção; Exatas x Humanas; Atuação dos professores.

Para o desenvolvimento da dissertação, foram criadas algumas subcategorias de análise, com base nos temas que apareceram com maior recorrência nas conversas. Por exemplo, no que se refere aos aplicativos, o WhatsApp foi citado por $100 \%$ dos entrevistados e seu código foi atribuído a 61 citações (que indicavam percepções dos estudantes sobre o uso do aplicativo em atividades de estudo). Para efeitos de comparação, o código 'Facebook' foi atribuído a 16 citações, seguido por 'E-mail' (14), 'YouTube' (12), 'Caderno/notas', 'Google Drive' e 'Dropbox' (10 cada), 'GeoGebra' (oito), 'Word' (quatro), 'Calculadora' (três), 'Agenda/calendário' (duas) e 'Google Fotos', 'One Drive' e 'Scanner' (uma cada). Além disso, os relatos apontaram que o aplicativo é utilizado para os principais usos do celular em atividades de estudo, daí a motivação para a criação da subcategoria 'WhatsApp', que serviu para discutir alguns dos modos de uso. As categorias e subcategorias de análise estão descritas no quadro a seguir: 
Quadro 2 - Categorias e subcategorias criadas para a análise de conteúdo

\begin{tabular}{|l|l|}
\hline \multicolumn{1}{|c|}{ CATEGORIAS } & \multicolumn{1}{c|}{ SUBCATEGORIAS } \\
\hline $\begin{array}{l}\text { 1) Usos do celular em atividades de } \\
\text { estudo }\end{array}$ & $\begin{array}{l}\text { a) WhatsApp } \\
\text { b) Leitura de textos }\end{array}$ \\
\hline 2) Motivações para o uso & $\begin{array}{l}\text { a) Mobilidade } \\
\text { b) Uso em sala de aula }\end{array}$ \\
\hline 3) Percepções sobre o uso & $\begin{array}{l}\text { a) Vantagens e ganhos } \\
\text { b) Desvantagens e prejuízos }\end{array}$ \\
\hline 4) Atenção & $\begin{array}{l}\text { a) Celular como fonte de distração } \\
\text { b) Celular como possibilidade de fuga } \\
\text { c) Estratégias de manejo da atenção }\end{array}$ \\
\hline 5) Exatas x Humanas & a) Geogebra \\
\hline 6) Atuação dos professores & - \\
\hline
\end{tabular}

Fonte: Elaborado pela autora com dados da pesquisa.

O próximo capítulo apresenta os dados produzidos a partir das entrevistas com os estudantes e a discussão sobre cada uma das categorias e subcategorias, em diálogo com referenciais teóricos e empíricos. 


\section{O que contaram os estudantes?}

\section{1.}

\section{Sobre os usos do celular em atividades cotidianas}

O corpus da análise de conteúdo constituiu-se de transcrições das 20 entrevistas realizadas durante o trabalho de campo. Os documentos de texto foram identificados pelos códigos EXT (Exatas) ou HUM (Humanas), referentes à área do conhecimento do curso do estudante, seguidos de números (1 a 20). O procedimento teve como objetivo identificar a área de conhecimento dos entrevistados e, ao mesmo tempo, garantir seu anonimato.

A partir de respostas obtidas na parte inicial do protocolo de entrevista ("Informações gerais sobre o uso do celular"), elaborou-se o Quadro 3, com a frequência de uso do celular em atividades gerais do cotidiano, de acordo com as seguintes opções: Todos os dias (TD); Muitas vezes na semana (MV); Poucas vezes na semana (PV); Raramente (R); Nunca $(\mathrm{N})$.

As respostas mostram que a maioria dos estudantes utiliza o celular todos os dias para ler e enviar mensagens instantâneas (18 entrevistados), acessar redes sociais (14) e navegar em sites (12). Por outro lado, a maior parte dos entrevistados afirmou que nunca ou raramente usa o celular para fazer vídeos (16) ou jogar (11). Ou seja, os estudantes utilizam mais o dispositivo em atividades relacionadas à comunicação interpessoal, exceto ligações telefônicas, e ao acesso à informação. Já o uso do celular para ações de cunho mais individual, que podem requerer um aparelho de melhor qualidade (no caso de fazer vídeos e fotografar) ou consomem dados móveis (como ouvir música e jogar), obteve frequências mais baixas - a exceção é assistir a vídeos, atividade em que a opção da maioria (13) foi por "muitas vezes na semana" ou "todos os dias".

Os resultados vão ao encontro de pesquisas sobre hábitos de uso da internet e de celulares realizadas no Brasil e no mundo (Telefónica Millenials Survey $2014^{10}$; Acesso à internet e à televisão e posse de telefone móvel celular para uso

\footnotetext{
10 Disponível em <http://www.telefonica.com.br/servlet/Satellite?c=Video\&cid=1386094 595726\&pagename=InstitucionalVivo\%2FVideo\%2FLayoutVideo>. Acesso em abr. 2018.
} 
pessoal: 2016 - IBGE ${ }^{11}$; Hábitos e Comportamento dos Usuários de redes sociais no Brasil E.life 2016², Pesquisa Nacional Fecomércio-RJ 2016 13 ; Digital in 2018 - We Are Social \& Hootsuite ${ }^{14}$; entre outras), que indicam os dispositivos móveis de comunicação como principais meios para acesso à internet, navegação em sites e uso de redes sociais.

11 Disponível em: <https://biblioteca.ibge.gov.br/visualizacao/livros/liv101543.pdf>. Acesso em abr. 2018.

12 Disponível em: < http://www.elife.com.br/estudohabitos/>. Acesso em abr. 2018.

13 Disponível em: <http://agenciabrasil.ebc.com.br/geral/noticia/2017-02/sete-em-cada-dezbrasileiros-acessam-internet-e-elevam-uso-de-smartphone>. Acesso em abr. 2018.

14 Disponível em: <https://wearesocial.com/blog/2018/01/global-digital-report-2018>. Acesso em abr. 2018. 
Quadro 3 - Frequências de uso do celular em atividades cotidianas (geral)

\begin{tabular}{|c|c|c|c|c|c|c|c|c|c|c|}
\hline & $\begin{array}{l}\text { Ligação } \\
\text { telefônica }\end{array}$ & $\begin{array}{l}\text { Navegar } \\
\text { em sites }\end{array}$ & $\begin{array}{c}\text { Acessar } \\
\text { redes } \\
\text { sociais }\end{array}$ & $\begin{array}{l}\text { Ler/enviar } \\
\text { e-mails }\end{array}$ & $\begin{array}{c}\text { Ler/enviar } \\
\text { mensagem } \\
\text { instantânea }\end{array}$ & $\begin{array}{l}\text { Ouvir } \\
\text { música }\end{array}$ & Fotografar & $\begin{array}{l}\text { Fazer } \\
\text { vídeos }\end{array}$ & $\begin{array}{c}\text { Assistir a } \\
\text { vídeos }\end{array}$ & Jogar \\
\hline EXT1 & $\mathrm{R}$ & TD & TD & TD & TD & MV & PV & $\mathrm{R}$ & $\mathrm{R}$ & $\mathrm{R}$ \\
\hline EXT3 & $\mathrm{R}$ & $\mathrm{PV}$ & PV & PV & TD & PV & PV & $\mathrm{PV}$ & $\mathrm{PV}$ & PV \\
\hline EXT4 & PV & $\mathrm{MV}$ & TD & TD & TD & TD & PV & $\mathrm{N}$ & MV & $\mathrm{N}$ \\
\hline EXT7 & PV & TD & TD & PV & TD & MV & PV & $\mathrm{R}$ & PV & PV \\
\hline EXT8 & PV & TD & TD & MV & TD & TD & TD & $\mathrm{R}$ & MV & PV \\
\hline EXT9 & MV & TD & TD & $\mathrm{MV}$ & TD & PV & PV & $\mathrm{R}$ & $\mathrm{MV}$ & TD \\
\hline EXT10 & PV & PV & MV & MV & TD & TD & MV & $\mathrm{R}$ & TD & $R$ \\
\hline EXT11 & PV & MV & TD & PV & TD & PV & PV & PV & MV & MV \\
\hline HUM3 & TD & TD & TD & MV & TD & TD & MV & MV & TD & MV \\
\hline HUM4 & $N$ & TD & MV & MV & TD & $\mathrm{R}$ & TD & PV & MV & MV \\
\hline HUM5 & PV & TD & TD & TD & TD & $\mathrm{R}$ & $\mathrm{R}$ & $\mathrm{R}$ & $\mathrm{MV}$ & $\mathrm{N}$ \\
\hline HUM6 & $\mathrm{N}$ & PV & TD & PV & TD & TD & $\mathrm{R}$ & $\mathrm{N}$ & PV & $\mathrm{N}$ \\
\hline HUM7 & $\mathrm{R}$ & TD & PV & TD & MV & TD & $\mathrm{R}$ & $\mathrm{R}$ & TD & PV \\
\hline HUM8 & TD & TD & TD & TD & TD & PV & PV & $\mathrm{R}$ & PV & $\mathrm{N}$ \\
\hline
\end{tabular}

Fonte: Elaborado pela autora, com base nas entrevistas realizadas durante o trabalho de campo.

Legenda: TD - Todos os dias; MV - Muitas vezes na semana; PV - Poucas vezes na semana; R - Raramente; N - Nunca. 
Quadro 4 - Frequências de uso do celular em atividades cotidianas por área de conhecimento (detalhado)

\begin{tabular}{|c|c|c|}
\hline Atividade & Exatas & Humanas \\
\hline Ligações telefônicas & $\begin{array}{l}\text { Poucas vezes }(8 / 12) \\
\text { Raramente }(3 / 12) \\
\text { Muitas vezes }(1 / 12)\end{array}$ & $\begin{array}{c}\text { Todos os dias }(3 / 8) \\
\text { Raramente }(2 / 8) \\
\text { Nunca }(2 / 8) \\
\text { Poucas vezes }(1 / 8)\end{array}$ \\
\hline Navegar em sites & $\begin{array}{l}\text { Todos os dias }(6 / 12) \\
\text { Muitas vezes }(3 / 12) \\
\text { Poucas vezes }(3 / 12)\end{array}$ & $\begin{array}{l}\text { Todos os dias }(6 / 8) \\
\text { Muitas vezes }(1 / 8) \\
\text { Poucas vezes }(1 / 8)\end{array}$ \\
\hline Acessar redes sociais & $\begin{array}{l}\text { Todos os dias }(9 / 12) \\
\text { Poucas vezes }(2 / 12) \\
\text { Muitas vezes }(1 / 12)\end{array}$ & $\begin{array}{l}\text { Todos os dias }(5 / 8) \\
\text { Muitas vezes }(2 / 8) \\
\text { Poucas vezes }(1 / 8)\end{array}$ \\
\hline Ler/enviar e-mails & $\begin{array}{l}\text { Muitas vezes }(5 / 12) \\
\text { Todos os dias }(4 / 12) \\
\text { Poucas vezes }(3 / 12)\end{array}$ & $\begin{array}{l}\text { Todos os dias }(4 / 8) \\
\text { Muitas vezes }(3 / 8) \\
\text { Poucas vezes }(1 / 8)\end{array}$ \\
\hline $\begin{array}{c}\text { Ler/enviar mensagem } \\
\text { instantânea }\end{array}$ & Todos os dias (12/12) & $\begin{array}{l}\text { Todos os dias }(6 / 8) \\
\text { Muitas vezes }(2 / 8)\end{array}$ \\
\hline Ouvir música & $\begin{array}{l}\text { Todos os dias }(4 / 12) \\
\text { Poucas vezes }(3 / 12) \\
\text { Muitas vezes }(2 / 12) \\
\text { Raramente }(2 / 12) \\
\text { Nunca }(1 / 12)\end{array}$ & $\begin{array}{c}\text { Todos os dias }(4 / 8) \\
\text { Raramente }(3 / 8) \\
\text { Poucas vezes }(1 / 8)\end{array}$ \\
\hline Fotografar & $\begin{array}{c}\text { Poucas vezes }(7 / 12) \\
\text { Muitas vezes }(3 / 12) \\
\text { Todos os dias }(1 / 12) \\
\text { Raramente }(1 / 12)\end{array}$ & $\begin{array}{c}\text { Raramente }(5 / 8) \\
\text { Muitas vezes }(1 / 8) \\
\text { Todos os dias }(1 / 8) \\
\text { Poucas vezes }(1 / 8)\end{array}$ \\
\hline Fazer vídeos & $\begin{array}{l}\text { Raramente }(8 / 12) \\
\text { Poucas vezes }(2 / 12) \\
\text { Nunca }(2 / 12)\end{array}$ & $\begin{array}{c}\text { Raramente }(5 / 8) \\
\text { Muitas vezes }(1 / 8) \\
\text { Poucas vezes }(1 / 8) \\
\text { Nunca }(1 / 8)\end{array}$ \\
\hline Assistir a vídeos & $\begin{array}{l}\text { Muitas vezes }(6 / 12) \\
\text { Poucas vezes }(3 / 12) \\
\text { Todas os dias }(2 / 12) \\
\text { Raramente }(1 / 12)\end{array}$ & $\begin{array}{l}\text { Todos os dias }(3 / 8) \\
\text { Poucas vezes }(3 / 8) \\
\text { Muitas vezes }(2 / 8)\end{array}$ \\
\hline Jogar & $\begin{array}{c}\text { Nunca }(5 / 12) \\
\text { Poucas vezes }(3 / 12) \\
\text { Raramente }(2 / 12) \\
\text { Todos os dias }(1 / 12) \\
\text { Muitas vezes }(1 / 12)\end{array}$ & $\begin{array}{c}\text { Nunca }(3 / 8) \\
\text { Muitas vezes }(2 / 8) \\
\text { Todos os dias }(1 / 8) \\
\text { Poucas vezes }(1 / 8) \\
\text { Raramente }(1 / 8)\end{array}$ \\
\hline
\end{tabular}

Fonte: Elaborado pela autora, com base nas entrevistas realizadas durante o trabalho de campo. 


\section{2}

\section{Sobre a relação com o celular}

As inovações tecnológicas, desde o desenvolvimento de dispositivos analógicos menos sofisticados aos mais recentes aparatos digitais e virtuais, podem provocar mudanças no comportamento e nos hábitos das pessoas (NICOLACI-DACOSTA, 2002). Não são raros os questionamentos sobre os efeitos da tecnologia e, com mais força recentemente, dos dispositivos móveis de comunicação - na vida dos indivíduos, e sobre o que seria uma relação saudável com os equipamentos tecnológicos utilizados cotidianamente.

Em 2008, surgiu no Reino Unido o termo nomofobia, que descreve "o desconforto ou ansiedade causado pela não disponibilidade de um telefone celular, computador pessoal ou qualquer outro dispositivo de comunicação virtual em indivíduos que os usam habitualmente" (KING et al., 2013, p.141, tradução da autora). A palavra vem da abreviação da expressão da língua inglesa no-mobilephone (nomo), que em tradução livre significa sem telefone celular, e tem sido relacionada à dependência ${ }^{15}$ do celular principalmente em notícias veiculadas pela mídia tradicional, como o jornal Extra ${ }^{16}$, o canal de televisão Globo News $^{17}$ e as revistas $I s t o E^{18}$ e Veja $^{19}$, para citar alguns veículos.

Para compreender o que os estudantes que participaram desta pesquisa pensam sobre sua relação cotidiana com o celular, uma das perguntas iniciais do protocolo de entrevista foi "Como você resume, de modo geral, sua relação com o celular?”. A intenção era que os entrevistados respondessem antes de entrar em detalhes sobre os modos de uso do dispositivo em atividades de estudo, ou seja, antes de refletirem sobre o assunto.

\footnotetext{
15 A questão da dependência relacionada às tecnologias é discutida, de forma mais ampla, nos campos da Psiquiatria e da Psicologia. Instituições como Universidade de São Paulo (http://www.dependenciadeinternet.com.br) e Universidade Federal do Rio de Janeiro (http://www.institutodelete.com), entre outras, mantêm ambulatórios voltados ao estudo e tratamento de transtornos relacionados ao uso excessivo e abusivo das tecnologias e da internet.

16 Disponível em <https://extra.globo.com/noticias/saude-e-ciencia/nomofobia-doenca-provocadependencia-do-celular-aprenda-perceber-os-sintomas-6593799.html > . Acesso em 8 fev. 2018.

17 Disponível em <http://g1.globo.com/globo-news/noticia/2015/10/confira-os-sintomas-danomofobia-dependencia-do-celular.html >. Acesso em 8 fev. 2018.

18 Disponível em <https://istoe.com.br/326665_VITIMAS+DA+DEPENDENCIA+DIGITAL/>. Acesso em 8 fev. 2018.

19 Disponível em <https://veja.abril.com.br/blog/letra-de-medico/nomofobia-a-dependencia-dotelefone-celular-este-e-o-seu-caso/>. Acesso em 8 fev. 2018.
} 
Dos 20 entrevistados, cinco mencionaram as palavras "dependência" e "vício" para descrever a relação com o celular, e outros sete deram indicações de que acreditam fazer um uso excessivo: "Ele é tudo, tudo"; "eu tô quase sempre com ele, é um porto seguro"; "uso muito mesmo"; "sou muito apegada ao meu celular, uso ele pra tudo"; "acho que já é mais um meio necessário pra mim”; "uso bastante o celular, mais que o recomendável pra uma pessoa normal"; "passo o dia inteiro com ele, só não tô com ele quando tô dormindo".

Já o uso do celular com moderação foi destacado por quatro estudantes, por meio da comparação com o comportamento de outras pessoas ("Música, mensagem e só, do meu grupo sou um dos que menos uso"; “Ao contrário de muitos, eu utilizo basicamente pra questões simples, questões de praticidade mesmo"; "Eu uso quando preciso, não sou maníaco") e pelo reforço do que não faz ("Não faço questão de ficar toda hora com o celular, não faço questão de colocar crédito pra ficar usando o $3 \mathrm{G}$, não fico 24 horas"). Os demais estudantes resumiram sua relação com base nas atividades que mais fazem com o celular, sem apresentar opinião sobre seu comportamento: "Conversa com amigos, conversa com crush e conversa com família"; "Pra assistir a uma série, ouvir uma música, o celular tá muito presente"; "Ela [a relação] está hoje também muito atrelada a minha atividade pedagógica"; "É o meu computador".

Outra questão do protocolo de entrevista indagou aos estudantes: "Como você se sentiria se não pudesse mais usar o celular em atividades de estudo?”. A pergunta constou da parte final do roteiro, após os estudantes conversarem com a pesquisadora. As respostas, de modo geral, reforçaram as avaliações iniciais sobre a relação com o dispositivo. Os entrevistados que focaram sua relação na dependência, vício ou uso excessivo do dispositivo corroboram o sentimento expressado anteriormente: "ia ficar completamente perdida, não ia lembrar de nada"; "acho que seria um choque muito grande, acho até irreal"; "me sentiria bem prejudicado"; "Bom, ia ter o computador em casa... Só acho que ficaria mais difícil"; "nossa, nem sei, imagina? Caramba, ia ser difícil”; "admito que se eu ficasse sem o celular durante uma semana eu teria vários problemas"; "acho que eu teria muito problema"; "eu teria que me adaptar bastante"; "nua; "constrangida, frustrada e muito triste, porque muita coisa seria perdida"; "ia ter que me virar de uma forma extremamente grande”; “ia ser meio ruim, né? Porque a gente já tá acostumado, aí quando tira é uma perda, como se tivesse faltando alguma coisa". 
Entre aqueles que disseram fazer uso moderado e os que explicaram a relação pela forma de uso, apenas um apresentou uma visão negativa ("dor nas costas pelo notebook, que é pesado. Com menos praticidade"). Outro entrevistado apontou uma vantagem de estar sem o celular ("Eu prestaria mais atenção nas aulas, com certeza") e os demais responderam que não veriam problema em ficar sem o dispositivo.

Algumas das manifestações apontam para uma visão do celular como meio de garantir a conexão com o mundo, a relação com as pessoas e o acesso aos elementos de que necessitam para suas atividades do dia a dia. Os entrevistados citam aspectos como necessidade e segurança para expressar e justificar o modo como utilizam seus dispositivos - que aparecem integrados e adaptados às rotinas existentes ou motivam novos hábitos. A colonização do cotidiano por novas práticas, sistemas e dispositivos tecnológicos de comunicação é observada por Amigo, Osorio e Bravo (2016, p.55), ao detectarem que as tecnologias de comunicação móvel dão continuidade à rede de relações interpessoais, que propiciam segurança e introduzem novas rotinas, usos e significados. Neste sentido, permitem a construção à distância de uma segurança ontológica ${ }^{20}$ (GIDDENS, 1991, apud AMIGO; OSORIO; BRAVO, 2016), uma vez que oferecem acesso a sistemas de comunicação institucionais e a um campo de relações contínuas e constantes.

\section{3.}

\section{Sobre o que fazem e como percebem o uso do celular em atividades de estudo}

A terceira e a quarta parte das entrevistas abordaram especificamente o uso do celular em atividades relacionadas à vida acadêmica e ao estudo. As seções a seguir detalham cada uma das categorias e subcategorias criadas para análise de conteúdo.

\footnotetext{
${ }^{20}$ De acordo com Giddens (1991, p. 95), segurança ontológica refere-se à crença dos indivíduos na "continuidade de sua autoidentidade e na constância dos ambientes de ação social e material circundantes".
} 


\subsection{1.}

\section{Usos do celular em atividades de estudo}

Esta categoria reúne menções dos entrevistados a qualquer ação relacionada à vida acadêmica ou ao estudo, realizada com o auxílio do celular. Os dados produzidos vão ao encontro de um dos objetivos específicos da pesquisa: Descrever os usos mais recorrentes do celular para fins de estudo entre os universitários entrevistados.

Os modos de uso mencionados pelos estudantes com maior frequência nas entrevistas foram:

- Acesso à informação e a conteúdos, por meio de busca na internet ou de consultas a material previamente armazenado. Este armazenamento acontece na memória do próprio celular; em contas de e-mail; em ambientes de armazenamento em nuvem ${ }^{21}$; em redes sociais, principalmente Facebook; ou em aplicativos de mensagem instantânea, sobretudo o WhatsApp.

- Compartilhamento de informação e materiais, enviados por e-mail, WhatsApp ou disponibilizados na nuvem.

- Comunicação instantânea, notadamente para obter informações sobre a rotina acadêmica - por exemplo, ser informado de que uma aula foi cancelada - e para questões práticas ligadas ao estudo (como entrar em contato com um ou mais colegas para resolver uma dúvida ou conseguir um conteúdo).

- Estudo em grupo, principalmente para dirimir dúvidas ou esclarecer algum ponto durante o estudo e, no caso dos estudantes das Ciências Exatas, para resolução conjunta de exercícios.

- Elaboração de trabalhos em grupo, via WhatsApp ou plataformas de nuvem. A maioria dos estudantes mencionou esta atividade, com posicionamentos favoráveis e contrários.

- Utilização de aplicativos (ou apps, na abreviação em inglês, que também será adotada nesta dissertação), em especial aqueles relacionados aos registros

\footnotetext{
21 Os ambientes de armazenamento em nuvem utilizam memória e capacidade de computadores e servidores compartilhados e interligados por meio da internet. Permitem o acesso a dados a qualquer hora, em qualquer lugar, e são disponibilizados aos usuários gratuitamente ou com acesso pago, de acordo com a capacidade disponibilizada. São exemplos de serviços populares de nuvem o Google Drive e o Dropbox.
} 
anteriores, como WhatsApp, ambientes de nuvem (Dropbox, Google Drive, One Drive) e e-mail. Também teve destaque entre os estudantes das Ciências Exatas apps para construção de gráficos 3D, sobretudo o GeoGebra, que será detalhado na seção 4.3.5.1 desta dissertação.

- Leitura de textos, que acontece principalmente em sala de aula, para acompanhar o texto trabalhado no dia, e no transporte público.

Outros usos foram mencionados com menor frequência ou não motivaram reflexões mais detalhadas na conversa com os entrevistados: fazer pesquisas na internet relacionadas ao estudo; gravar áudios em sala de aula; registrar em foto o conteúdo do quadro; assistir a videoaulas para complementar ou entender melhor um tema abordado em aula; utilizar o celular como caderno ou bloco de notas; fazer revisão ou edição rápida de trabalhos; utilizar agenda e aplicativos relacionados à organização da vida acadêmica.

Aspectos pertinentes aos usos identificados estão detalhados nas próximas seções. Por ser um recurso adotado por todos os entrevistados em diferentes atividades, o aplicativo WhatsApp serve como fio condutor para a discussão sobre alguns dos usos identificados.

\subsubsection{1.}

\section{What's up? E aí?}

Utilizado por mais de 1 bilhão de pessoas, em mais de 180 países $^{22}$, o WhatsApp (trocadilho com a expressão "What's up?", que em tradução livre do inglês significa “E aí?”) é um aplicativo que disponibiliza serviços de mensagens e chamadas instantâneas gratuitas e permite o envio e o recebimento de fotos, vídeos, documentos, localização, textos e áudios. Além dos contatos individuais, o WhatsApp permite a criação de grupos, para conversas compartilhadas.

Os 20 entrevistados mencionaram o uso do WhatsApp em atividades relacionadas à vida acadêmica de modo mais geral e/ou em atividades de comunicação instantânea, acesso a conteúdo, compartilhamento de materiais,

22 De acordo com dados do ano de 2018 da WhatsApp Inc. 
elaboração de trabalhos e de estudo em grupo. Ou seja, o aplicativo apareceu como o recurso mais utilizado pelos estudantes que participaram da pesquisa, tanto em atividades gerais do cotidiano (conforme apresentado no Quadro 3) como naquelas relacionadas ao estudo.

A interação dos estudantes via WhatsApp acontece sobretudo por meio da participação em grupos criados no aplicativo. De acordo com os relatos, há grupos maiores, formados pelos estudantes do curso todo ou de uma turma (em geral, a do ano de ingresso no curso); grupos formados por estudantes que frequentam uma determinada disciplina; e grupos menores, criados apenas para a realização de trabalhos específicos ou para estudo de alguma matéria ou um tópico do currículo. Segundo os entrevistados, na maioria dos casos a iniciativa de criação dos grupos é dos próprios alunos, mas há situações em que os professores fazem a proposta. Os trechos a seguir abordam a criação e o funcionamento desses grupos.

Eu participo de vários grupos [...] São grupos de grupos, as pessoas se organizam pra fazer um trabalho em grupo e aí a gente faz um grupo no WhatsApp. (EXT5)

Algum tempo atrás, na criação do grupo da turma pra poder tratar de assuntos com relação a se vai ter aula, se vai ter greve, se vai ter comida no bandejão, que horas que vai sair, cadê o professor, tava atrapalhando muito, os assuntos se embaralhando. Tava meio confuso porque misturava matéria com outras coisas. Então o que o professor começou a fazer, se tem dificuldade na matéria ou quer separar pra fazer exercícios, cria um grupo específico da matéria no WhatsApp. Então hoje a gente tem um grupo que trata somente de resolução de exercícios e fotos da aula. A gente tem um grupo que é só isso. (EXT7)

Geralmente no início do semestre o professor prefere fazer um grupo, ele coloca todos os alunos da turma, e aí manda material, ou então acontece alguma coisa, ele não pode dar aula e aí avisa pelo grupo. (EXT8)

No WhatsApp tem o grupo da turma e grupos de trabalho, quando a gente precisa fazer algum trabalho. Esse mesmo que te falei, do Drive, a gente criou um grupo, são quatro pessoas. A gente criou o grupo pra não ficar mandando mensagem pra cada um. Se tem a facilidade a gente cria. Então para fins acadêmicos são grupos de trabalho e o grupo da turma. E grupos das disciplinas, né? Porque cada disciplina às vezes quer fazer um grupo, então a gente entra e no final do período a gente sai. (HUM2) 
Os estudantes mencionam como principal uso do WhatsApp a comunicação instantânea com os colegas e professores, para troca de informações práticas como o cancelamento de alguma aula, avisos sobre matéria dada, atividades programadas para os próximos encontros, entre outras. Há ainda compartilhamento de materiais como fotos de apontamentos do professor no quadro, registros de slides apresentados em sala ou arquivos e links de textos a serem lidos para aulas seguintes. A maioria dos estudantes citou o WhatsApp como principal meio para essa comunicação instantânea - houve relatos também desse tipo de atividade pelo Facebook e pelo e-mail, com menos frequência.

O compartilhamento de conteúdo entre os estudantes, via celular, é apontado por Bannell et al. (2016) como positivo, uma vez que essa troca de informações permite um compartilhamento de ideias que pode auxiliar o estudo.

[...] lembramos da época em que se pedia o caderno ao amigo da escola, para copiar o que se havia perdido ou a matéria referente à aula à qual não se foi. Hoje isso pode ser feito em segundos, dependendo apenas da internet. Dificilmente copiamos ou vemos companheiros de turma anotando o que está no quadro. É claro que isso faz parte dos paradigmas a serem quebrados, mas temos certeza de que o uso de aplicativos de mensagens, como WhatsApp ou Viber e e-mails, é mais útil quando o assunto é praticidade e rapidez. O celular permite compartilhar alguns textos que podem ser transmitidos facilmente, compartilhar links e vídeos que sejam interessantes e tenham relação com o assunto estudado. (BANNELL et al., 2016, p. 144)

O WhatsApp é também utilizado para organização e elaboração de trabalhos em grupo. Os relatos indicam que é cada vez mais comum, ao receber a demanda de realização desse tipo de atividade, que os alunos criem um grupo no aplicativo para distribuir as tarefas (quem faz o quê), trocar materiais e também para se comunicar durante o andamento da elaboração do trabalho. Esta dinâmica, porém, não é consenso entre os estudantes que participaram da pesquisa. Alguns avaliam como vantagem, principalmente em termos de otimização do tempo, o fato de não precisarem mais fazer reuniões presenciais. Outros estudantes, no entanto, consideram que a discussão apenas via WhatsApp prejudica a qualidade do trabalho. As falas a seguir evidenciam visões divergentes:

Hoje em dia você não precisa mais se encontrar, esse é um bom ponto. Você não precisa mais se encontrar pra estudar, fazer 
como se fosse um grupo de estudo, nem pra fazer um trabalho. Tem vários trabalhos que já fiz e que a gente não se reuniu. Foi só discutindo através do WhatsApp, via texto, via áudio. (EXT2)

[...] essa é uma coisa que prefiro fazer pelo celular. Porque funciona melhor, é bem mais rápido quando se trata dessa troca de mensagem, discussões, pra discutir um tema de um trabalho. (EXT3)

Foram poucos trabalhos em grupo até agora, mas teve um que a gente fez em grupo e resolveu tudo pelo WhatsApp. Não ficou aquele trabalho maravilhoso, né, mas ficou um trabalho. A gente dividiu o tema em partes, dividiu pelo WhatsApp quem ia ficar responsável pelo quê. E aí a pessoa falava 'ah, mandei tal coisa', mandava o arquivo por e-mail, a gente via e discutia no WhatsApp o que podia mudar, o que podia acrescentar. (HUM8)

Agora, quando é um trabalho que precisa escrever uma, duas, três laudas, aí tem que ler, discutir, realmente, é..., acaba se tornando um pouco mais complicado. Porque muita gente quer fazer isso via WhatsApp, via e-mail, via Facebook, mas tem algumas questões que precisa discutir, precisa estar frente a frente para debater, porque acaba ficando um pouco bagunçado. Você está falando, numa conversa, você fala, o outro espera você falar pra falar também, e assim vai. No WhatsApp é muita informação, é muita gente dando pitaco, acaba se perdendo um pouco ali. Então coisas importantes acabam não sendo ditas, porque é muita gente falando ao mesmo tempo. (HUM3)

[...] vejo que nos grupos do WhatsApp, principalmente para formação de grupo para estudo, esse distanciamento acabo vendo que é uma desvantagem. Para você apresentar um trabalho que é num grupo você precisa ter essa interação no real. (HUM4)

O aplicativo aparece ainda como plataforma para estudo em grupo, principalmente entre os estudantes das Exatas, muitos dos quais relataram a prática de resolução de exercícios em conjunto. A plataforma foi citada de modo positivo como um espaço para fazer perguntas e trocar informações sobre determinados tópicos, como pode ser observado nos seguintes comentários:

[...] por exemplo, se surgir alguma dúvida eu vou pro WhatsApp, ou vou pra algum lugar, o Discórdia, por exemplo, pra tentar tirar essa dúvida com outras pessoas que já estão fazendo ou não fazendo. Porque é muito comum, não sei se em outros lugares e outros cursos também é assim, mas é muito comum pra gente estudar junto. (EXT1)

É ótimo pra pegar o conteúdo. Se você faltou a aula, o pessoal disponibiliza em tempo real a foto da matéria, com anotações que cada um tenha feito. O pessoal tá ali tirando dúvidas na hora, 
fazendo a resolução dos exercícios em conjunto. O grupo tem funcionado bastante. (EXT7)

[...] então os alunos mesmos fazem um grupo pra conversar sobre a matéria. Aí cada um dá uma ideia de resolução, se alguém conseguiu resolver manda a foto do caderno pro grupo. (EXT8)

A imagem a seguir exemplifica uma troca de mensagens, via WhatsApp, sobre a resolução de exercícios. Nota-se que há uma explicação detalhada do caminho traçado para chegar ao resultado, com referências a um conteúdo teórico ("lema do caderno") e à resolução desenvolvida em outra questão. Há também uma indicação sobre a possível forma de resolver um dos problemas ("imagino que a d saia da mesma forma").

Imagem 1 - Troca de mensagens em grupo do WhatsApp

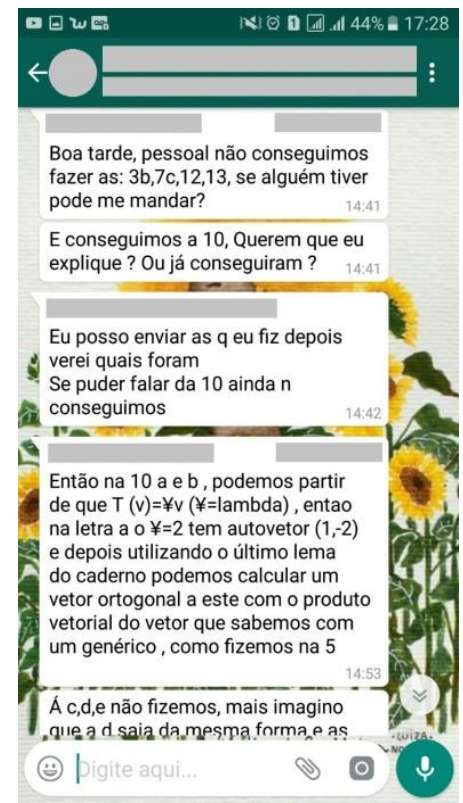

Fonte: Arquivo da pesquisa.

Entre os entrevistados das Ciências Exatas, a prática de estudo em grupo via celular está mais focada na resolução de exercícios. No caso dos alunos de Humanas, os relatos de estudo em grupo apareceram mais relacionados à explicação de alguma dúvida específica ou ao compartilhamento de material e conteúdo, como nas citações a seguir: 
Aí se eu tenho uma dúvida eu coloco essa dúvida. Se alguém entendeu, vai lá, marca o meu comentário e responde embaixo 'ó, o professor explicou assim, assim, assim. Mas assim é mais simples'. Aí dá alguma analogia, ah, tá entendi. Ou então todo mundo tá estudando pra prova, 'ah, alguém entendeu o tópico tal do texto?', 'ah, tenho aqui um outro texto que ajuda'. Vira uma rede acadêmica ali mesmo, que facilita a gente a uns ajudarem os outros. (HUM1)

Acabamos criando grupos instantâneos, porque a gente cria o grupo pra estudar. Aí realmente há possibilidade de debate. A gente debate on-line, porque às vezes o contato é muito complexo, porque cada um tem uma realidade de vida, então a gente vem utilizando o grupo do WhatsApp para isso. A gente consegue debater sobre o que cada um quer fazer e a gente acaba discutindo ali e marcando sempre um ponto de encontro também. (HUM4)

O estudo em grupo, principalmente pelo WhatsApp mas também em outros aplicativos, é visto de forma positiva por alguns dos entrevistados. O principal benefício apontado por eles está no fato de poderem elucidar uma dúvida no momento do estudo, sem precisar esperar um encontro com colegas, monitores ou com o professor na universidade - o que poderia acontecer somente dias depois daquele momento. As passagens adiante exemplificam algumas interações.

A própria comunicação com o professor, fico imaginando que antigamente o professor... Primeiro que não tinha celular antigamente, o professor não dava o telefone da casa dele, né? Então pra você falar com o professor era na faculdade. Tem professores que são mais abertos e inclusive eu tenho eles no Facebook. Tem professor que tem grupo no Facebook. Eu não mando mensagem direto pra não ser invasivo, mas, por exemplo, tem um grupo da matéria, eu fiz uma pergunta com uma mensagem no grupo, e o professor respondeu. Então é mais fácil de chegar ao professor. (EXT2)

Até com monitores, eu costumo pegar o contato de monitor e uso mesmo. Eles ajudam, na última prova o monitor não pôde vir e a gente ficou duas horas via Messenger do Facebook. Eu mandei as questões, ele respondendo e tal. Foi antes da prova, foi de quatro às seis e minha prova era de oito às dez. A gente ficou lá fazendo as questões, ele me mandava foto, eu olhava. Até que uma das quatro questões que eu tinha pedido a ele caiu na prova e eu fui bem, até por isso. A conversa ajudou bastante. (EXT11)

Outros estudantes, entretanto, apontaram dificuldades em estudar em grupo por meio do WhatsApp. A principal queixa foi o excesso de informação e de conversas alheias ao estudo, além da possibilidade de mal-entendidos. 
E eu acho que fica confuso discutir matéria, conteúdo, como se faz essa questão, via internet, acho que fica confuso. Normalmente, se for falar comigo pra saber o que eu acho, se tá certo, eu vou falar pra me encontrar na biblioteca, na aula. Mas, assim, é um meio de comunicação pra tirar essa dúvida, só que eu não vou tirar por ali. Só se for muita emergência e a pessoa precisar muito. Mesmo assim eu mando áudio, pra tentar ficar mais natural. (EXT9)

Prefiro conversar pessoalmente, porque as palavras podem trazer duplo sentido e você pode não ter aquele resultado que você esperaria ter, então sou muito mais a favor que as coisas sejam pessoalmente do que no virtual. E tem uma coisa que tô pra falar, se me dessem uma opção de fazer o curso presencial ou a distância, eu preferiria o presencial. Apesar de todas as questões e desvantagens, talvez seja uma questão de disciplina, não sei. Porque quando você tem uma dúvida, com o monitor que tá lá você não tem a sua dúvida tirada completamente. Eu sei porque já fiz matérias a distância num outro curso. Agora imagina um curso de Filosofia a distância? Eu tinha dúvida e aí era 'leia a parte tal novamente que você vai compreender'. Não tirava a minha dúvida, é diferente de estar com o professor aqui. Pra mim, em termos de estudo, não funciona. (EXT12)

Isso eu acho um problema da interação com o computador no geral. Porque muitas vezes a gente fala as coisas e não sai com a entonação que a gente deseja. E por acabar gerando muito problema. Já aconteceu comigo várias vezes, de eu estar conversando com uma pessoa numa boa, falar alguma coisa e ela entender errado, ou eu entender errado. Tipo, tá me atacando. Isso eu acho muito preocupante. Não sei se tem um modo pra melhorar isso, e também é chato ficar explicando toda hora, 'ah, não foi isso', é chato. Eu acho melhor encontrar pessoalmente, porque a dinâmica muda, acho que sai mais coisa. (HUM5)

Pelo WhatsApp não funciona. Pelo menos não pra mim, não sei se pra quem tá do outro lado funciona. Porque perde o foco. Ao mesmo tempo em que está tendo a discussão aqui tem uma conversa nada a ver do outro lado. (HUM6)

A utilização do WhatsApp em atividades relacionadas à vida acadêmica e ao estudo, e também como recurso pedagógico, é apontada também por outras pesquisas (TIMMIS, 2012; BOUHNIK; DESHEN, 2014; KAIESKI; GRINGS; FETTER, 2015; AL-EMRAN; ELSHERIF; SHAALAN, 2016; PAIVA; FERREIRA; CORLETT, 2016; para citar algumas). Bottentuit Junior, Albuquerque e Coutinho (2016) apresentam uma relação de vantagens e desvantagens do uso do aplicativo na área educacional. 
Quadro 4 - Vantagens e desvantagens do uso do WhatsApp no campo da Educação

\begin{tabular}{|c|c|}
\hline Vantagens do WhatsApp & Desvantagens do WhatsApp \\
\hline $\begin{array}{l}\text { - Interatividade e facilidade de acesso; } \\
\text { - Compartilhamento de conhecimento } \\
\text { professor-aluno, aluno-aluno; } \\
\text { - Possibilita uma comunicação síncrona e } \\
\text { assíncrona; } \\
\text { - Permite um maior diálogo e } \\
\text { problematização dos temas; } \\
\text { - Ferramenta motivadora dentro e fora de } \\
\text { sala de aula; } \\
\text { - Permite esclarecer dúvidas fora da sala de } \\
\text { aula; } \\
\text { - Permite compartilhar informação em } \\
\text { múltiplos formatos (texto, áudio, vídeo e } \\
\text { documentos). }\end{array}$ & $\begin{array}{l}\text { - Pode distrair ou desviar o foco de atenção } \\
\text { dos alunos; } \\
\text { - Necessita de acesso à Internet para } \\
\text { funcionar; } \\
\text { - Os alunos necessitam de telefones mais } \\
\text { modernos para utilizar a ferramenta. }\end{array}$ \\
\hline
\end{tabular}

Fonte: BOTTENTUIT JUNIOR; ALBUQUERQUE; COUTINHO, 2016, p. 72.

No que se refere às vantagens indicadas pelos autores, nas entrevistas apenas a possibilidade de maior diálogo e problematização dos temas não apareceu explicitamente. Ao contrário, há comentários sobre problemas de entendimento e superficialidade das conversas via WhatsApp, o que pode evidenciar uma dificuldade dos estudantes em fazer a transposição do pensamento para a escrita no dispositivo móvel, que exige, entre outras habilidades, destreza no manejo do teclado virtual, aliada à expectativa de agilidade nas respostas.

Quanto às desvantagens, a questão do acesso à internet e do tipo de celular não foi apontada pelos entrevistados em relação ao uso do WhatsApp (todos utilizam diariamente ou muitas vezes na semana o aplicativo). Já a possibilidade de distração teve destaque entre os estudantes, porém não apenas atrelada ao uso do aplicativo, mas também a outras funcionalidades do celular e à navegação na internet de modo geral, como será abordado nas seções 4.3.3, sobre percepções do uso, e 4.3.4, sobre atenção. 


\subsubsection{2.}

\section{Leitura de textos: na tela ou no papel?}

Em 2014, a Unesco publicou um estudo sobre leitura na era móvel ${ }^{23}$, no qual destacava que os dispositivos móveis favoreciam as práticas de leitura principalmente em países em desenvolvimento. Num dos trechos, o relatório indica que um dos meios de ampliar o acesso de populações menos favorecidas a livros e textos seriam os dispositivos móveis, particularmente o telefone celular. "Por que os celulares? Porque as pessoas os têm", pontua o documento.

O uso de celular para leitura de textos acadêmicos apareceu nas conversas com os entrevistados desta pesquisa. Do total de estudantes, cinco disseram preferir ou não ver problemas na leitura pelo celular. Os demais (15) preferem ler no papel ou no computador, mas alguns recorrem ao celular por questões financeiras ou relacionadas ao fato de estarem sempre com o dispositivo e poderem acessá-lo em qualquer lugar.

Entre os que fazem a leitura na tela, as justificativas incluem a redução de custo com impressão e fotocópias e a praticidade de não precisar carregar folha de papel ou livros, o que facilita a leitura em movimento. De acordo com os relatos, a leitura acontece principalmente em sala de aula, para acompanhar os textos ou materiais trabalhados durante a atividade proposta na disciplina, e no transporte público, para aproveitar o tempo do trajeto.

Enfim, o celular para mim já passou o livro de longe na forma de ler. Talvez tenha gente que prefira o livro, não sei, mas eu... Até pelo custo, por ter que pegar na biblioteca. É muito mais fácil, o celular é um facilitador sim. (EXT2)

O tempo que eu fico em casa é curto, porque eu moro um pouco longe e a maior parte do tempo eu passo no transporte, vindo e voltando. E aí tem o tempo do trem, então realmente, tem um conteúdo pra estudar, vai ter uma prova e tenho que revisar alguma coisa. Aí eu passo pro celular, chego lá no trem, eu sempre vou sentado porque eu pego na estação final, e venho o caminho todo consultando pelo celular. (EXT3)

Eu uso bastante pra ler. Por exemplo, tô no trajeto do ônibus e tem alguma aula que não li o texto, ou não li um pedaço, sabe,

23 Disponível em <http://unesdoc.unesco.org/images/0022/002274/227436e.pdf>. Acesso em 26 mar. 2018. 
pra não perder tempo. [...] E até mesmo nas aulas a gente usa pra poder acompanhar, porque ficar gastando dinheiro com xérox a galera não pode, ou não tem impressora. Então é mais fácil. (HUM5)

Alguns estudantes, no entanto, mencionaram dificuldades de ler no celular em comparação ao papel, principalmente se o tema for mais complexo ou se tiverem dúvidas quanto ao conteúdo.

Quando eu vejo que tô um pouco mais perdida em tal matéria eu prefiro ter o material físico, que eu acho que me traz mais perto pra matéria. Acho mais fácil de compreender, bem mais. (EXT9)

Geralmente eu usava mais texto físico mesmo, então passar disso pra digital, por mais que seja bom e economize tempo e dinheiro, parece que não tô absorvendo muita coisa. (HUM5)

Mesmo aqueles que optam por ler no celular apontam problemas, como indica a fala a seguir:

No papel você tem o costume de ler, fazer anotações, grifar. No celular você já não tem tudo isso, dependendo do aplicativo que você usa. Eu até encontrei alguns que você pode usar o marcador pra texto, escrever... Mas acho que não é a mesma coisa, o entendimento não fica... Não sei explicar, porque não devia ter essa diferença, mas no papel realmente facilita. Você volta, lê de novo, faz o link de uma coisa que tem a ver numa página com outra do que você estava lendo. No celular é aquela coisa de 'ai, não sei onde é que tá', volta, volta, volta, perdi. É útil, mas, assim, não é a mesma coisa. Mas eu uso, mesmo com essa limitação. (HUM1)

Por outro lado, um dos estudantes relatou que o celular facilita sua concentração na leitura, por exigir a rolagem da tela e, assim, manter a atenção no dispositivo:

Não tem quando você tá lendo, chega lá embaixo e percebe 'caraca, não entendi nada daquilo'? É mais ou menos a mesma coisa, parece que eu li e não entendi, tenho que voltar um pouquinho. Mas isso acontece mais com eu lendo livro impresso do que no celular. Porque eu li lá em cima 'bola', continuo lendo, mas minha cabeça continua pensando em futebol. É meio louca a minha cabeça. Aí tem que voltar tudo pra entender o que já li. [...] No celular acontece menos. Acho que é porque eu fico fazendo assim [simula rolagem de tela], aí eu fico acompanhando, conforme vou mexendo o dedo, vai mexendo 
outras coisas, sei lá. Porque só ler eu me perco um pouquinho. (HUM8)

O uso de dispositivos eletrônicos para leitura provoca, como ressalta Chartier (1998), mudanças não apenas no suporte do material escrito - que passa das folhas e páginas manuseáveis para o texto na tela, sequencial e contínua, sem fronteiras visíveis -, mas também nas maneiras de ler. O autor reconhece o efeito, na leitura, produzido pela forma do texto, uma vez que há diferenças em sua organização e na estrutura de recepção.

Um romance de Balzac pode ser diferente, sem que uma linha do texto tenha mudado, caso ele seja publicado em um folhetim, em um livro para os gabinetes de leitura, ou junto com outros romances, incluído em um volume de obras completas. (CHARTIER, 1998, p. 138)

A visão de Chartier pode explicar algumas das diferenças percebidas pelos estudantes na comparação entre textos impressos e aqueles lidos na tela do celular - maior ou menor dificuldade de concentração, por exemplo. No entanto, de modo geral, os relatos indicam que os entrevistados utilizam o dispositivo para fazer uma leitura similar a que se faz no papel, seguindo o texto de forma linear e não interativa, principalmente aqueles em formato PDF (Portable Document Format) ${ }^{24}$. Poucos mencionaram o uso de recursos disponíveis nos aplicativos e plataformas de leitura eletrônica, como destacar parte do texto ou fazer notas no documento. Este padrão de uso, juntamente com a dificuldade de leitura na tela, apontada por alguns, e com a preferência pelos textos impressos, ressaltada por outros, vai de encontro ao que Soares (2002, p.151) preconiza como letramento digital: “[...] isto é, um certo estado ou condição que adquirem os que se apropriam da nova tecnologia digital e exercem práticas de leitura e de escrita na tela". No caso dos participantes da pesquisa, as práticas relatadas se assemelham ao letramento dos que fazem a leitura e a escrita no papel.

Além disso, as atividades de leitura e escrita realizadas por meio dos dispositivos móveis de comunicação incluem a circulação por ambientes hipermídia, que reúnem elementos textuais, imagens, sons, vídeos. O trânsito por

\footnotetext{
24 Documentos descritos em arquivos PDF podem conter textos, gráficos e imagens, gerados a partir de outros formatos.
} 
este sistema de comunicação multimodal, multimídia e portátil, como apontado por Santaella (2013, p. 279), exige do usuário determinadas competências: "a capacidade de enxergar os problemas de múltiplos pontos de vista, assimilar a informação e improvisar em resposta ao fluxo acelerado dos textos e imagens em um ambiente mutável". Os entraves descritos por parte dos entrevistados podem indicar que tais competências ainda não estão plenamente desenvolvidas em alguns estudantes, apesar do uso constante do celular para leitura por eles evidenciado.

\subsection{2.}

\section{Motivações para o uso}

O segundo objetivo específico deste estudo foi Compreender as principais motivações dos estudantes para utilização dos dispositivos nas atividades relacionadas ao estudo, a partir do qual foi criada a categoria de análise "Motivações para o uso". Esta categoria reúne justificativas dos estudantes para os usos que fazem do celular em atividades de estudo. Dois temas sobressaíram das falas dos entrevistados e serão detalhados a seguir: a mobilidade e o uso em sala de aula.

\subsubsection{1.}

\section{A qualquer hora, em qualquer lugar: a questão da mobilidade}

A possibilidade de utilizar o celular e usufruir de todas as suas funcionalidades em qualquer lugar, a qualquer momento - ou seja, a característica da mobilidade - foi o aspecto que mais se destacou nas conversas com os estudantes, no que se refere às motivações para o uso. A presença constante do dispositivo móvel é vista, de forma geral, como positiva pelos estudantes para questões relacionadas ao estudo, pois permite que realizem as atividades descritas na categoria anterior onde quer que estejam, especialmente acessar conteúdos, obter e transmitir informações de interesse do grupo, fazer edições rápidas em trabalhos e conversar com colegas. Tal entendimento foi também apontado por autores 
(SOUSA, 2014; FOTI; MENDEZ, 2014; FERREIRA, 2015) relacionados na revisão de pesquisas empíricas.

As citações a seguir apresentam algumas percepções dos estudantes sobre as vantagens de ter um dispositivo móvel de comunicação a seu dispor:

Várias vezes eu tô discutindo um trabalho em grupo e estou na rua, entendeu? O computador tem essa chateação de que você tem que estar em casa, ninguém anda com computador pra lá e pra cá. Nem com notebook eu ando. (EXT2)

Acho que a principal vantagem do celular hoje em dia é que você tá sempre apto a fazer o que você precisa em qualquer lugar que você esteja. Ele tem esses recursos. Muitas vezes pode até não ser tão bom quanto o computador, mas é possível realizar essas tarefas nele. (EXT3)

Então a gente está sempre conectado pelo menos nessas três plataformas [Gmail, Dropbox e Google Drive]. Eu acho isso muito prático, porque você pega no celular. Você esqueceu o caderno em casa, esqueceu o livro, não precisa nem vir com mochila, celular num bolso, carteira no outro. Chega na sala, abre o Dropbox, abre o Drive, vê o exercício que ele tá botando no quadro, vê o livro ali que tá na tua mão. Então é uma parada muito prática e muito acessível, você tá com tudo ali na hora, em tempo real. (EXT10)

A vantagem é a praticidade de você, por exemplo, eu tava aqui e não precisei subir lá. Ou às vezes a sala de computador tá fechada, por isso que eu assisto vídeos muitas vezes aqui [biblioteca] mesmo. Boto o wi-fi, assisto a videoaula e tô resolvendo aqui na mesa mesmo. E estar tudo num local só, é muito mais fácil. Acho muito mais fácil estudar pelo celular do que pelo computador. (EXT11)

Porém, você há de convir que é muito mais prático eu estar com o telefone em sala de aula do que com um notebook, do que até com um tablet. Por conta de peso, por conta de espaço, tudo mais. Então o telefone tá ali, na mão. Se eu preciso ver um vídeo, ler um texto, eu não preciso estar com aquele trombolho na minha frente, se eu tô com o telefone, acho que a facilidade já começa por aí. (HUM2)

O celular me possibilitou poder escrever a qualquer momento, de fato. A questão da praticidade, porque o notebook parece que veio num momento pra você usar em vários lugares, mas o celular hoje possibilita reduzir o peso literalmente, mas sem perder a qualidade. Então eu uso muito o Word, eu escrevo meus trabalhos acadêmicos também. E tenho feito muitas pesquisas de textos acadêmicos e leituras através do celular. Isso tá no cotidiano e tem me favorecido nesse ponto. Consigo ter acesso a 
esses materiais para estudo a qualquer momento, em qualquer espaço também. (HUM4)

Os dispositivos móveis de comunicação possibilitam o que se caracteriza como mobilidade ampliada (LEMOS, 2009), em que há uma potencialização das dimensões física e informacional - a primeira não aparece mais como empecilho para a segunda. Como ressaltaram alguns estudantes, não é necessário ir à biblioteca para consultar determinado conteúdo, nem esperar chegar a casa para corrigir um erro percebido num texto ou chegar à universidade para saber que não haverá aula. Essa dinâmica é descrita por Bauman (2001, p. 18) como "'golpe de misericórdia' simbólico na dependência em relação ao espaço".

Como descrito na seção 4.3.1.2, sobre leitura de textos, há estudantes que utilizam o celular durante seus trajetos no transporte público - alguns deles informaram morar a grandes distâncias da Unirio, localizada no bairro da Urca, zona sul do Rio de Janeiro, e aproveitar o tempo ocioso é também uma de suas motivações para o uso do celular em atividades de estudo. Assim, para a maioria dos entrevistados, ainda que o dispositivo não ofereça todas as funcionalidades do computador, o fato de estar "sempre à mão" o torna um facilitador, termo utilizado por alguns dos estudantes.

A comparação entre o computador pessoal e o celular apareceu em todas as entrevistas. A maioria dos participantes prefere utilizar o computador para elaborar textos e trabalhos com exigências de formatação, uso de imagens, criação de slides, entre outros. Para eles, o celular ainda apresenta limitações técnicas que dificultam sua utilização nestes fins, entre elas o tamanho reduzido do teclado e da tela, menor capacidade de processamento e versões mobile de programas com menos funcionalidades. Assim, o dispositivo móvel é utilizado com mais frequência para leitura e, no caso da escrita, para comunicações instantâneas e edição rápida de conteúdo.

Apenas um estudante relatou que utiliza o celular como substituto ao computador pessoal, para realização de trabalhos completos da faculdade e demais funções, com o apoio de um teclado portátil conectado remotamente ao aparelho. Para ele, a motivação principal para o uso do celular foi não ter um computador em casa e o fato de que os equipamentos disponíveis na universidade não atendem de forma suficiente à demanda dos alunos. 
Eu aderi a ele [celular] também por necessidade, tanto que eu adquiri um teclado portátil, que eu conecto com um adaptador no celular, e facilita escrever, fazer trabalho. Esse ano de 2017 foi o que me salvou. [...] É um quebra galho, mas tem me servido de forma extraordinária. Aqui na faculdade, na biblioteca, tem computadores, mas muitas vezes tá cheio, então acabei preferindo. Pesquisei antes, adquiri esse teclado. Não é o ideal, mas é o que me serve e serve bem. (HUM7)

A fala se aproxima da reflexão de Castells et al. (2011, p. 344) sobre o modo como os indivíduos se apropriam dos recursos tecnológicos: "Cada grupo se apropria da tecnologia conforme suas práticas e necessidades de comunicação, mas também de acordo com suas restrições de recursos".

A Imagem 2 mostra o momento em que o jovem utiliza o teclado portátil para exemplificar o uso do editor de textos pelo celular. $\mathrm{O}$ estudante afirma que, após a adaptação inicial ao teclado e aos programas utilizados no celular, não vê muita diferença entre realizar suas tarefas no dispositivo móvel e no computador. 
Imagem 2 - Estudante com teclado conectado remotamente ao celular

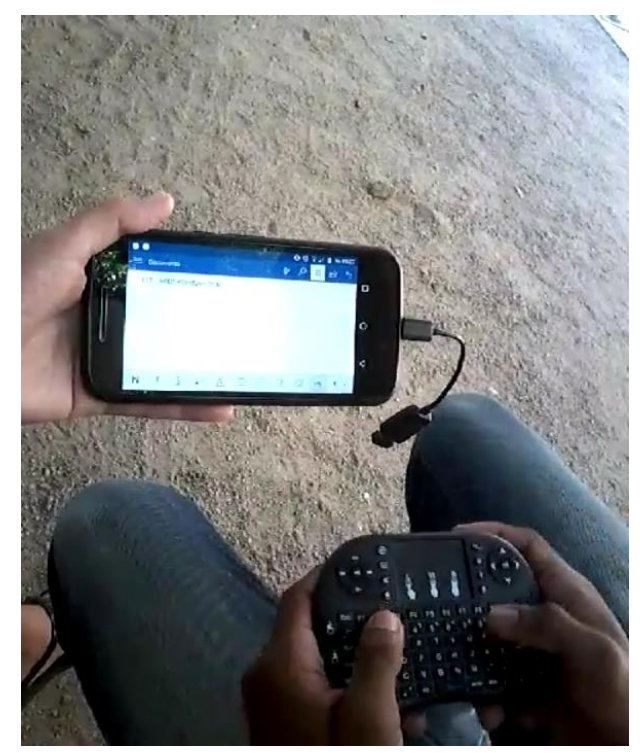

Foto: Arquivo da pesquisa.

As limitações técnicas do dispositivo aparecem, por outro lado, em oposição a relatos que atrelam o uso do celular à praticidade, em comparação a outros equipamentos. Alguns estudantes destacaram como positivo o fato de carregarem menos peso, seja de um notebook, de livros ou de folhas de fotocópias. Mesmo em casa, a praticidade de estar com o celular na mão foi apontada por alguns entrevistados como vantagem e também como fonte de desestímulo para uso de outros equipamentos. $\mathrm{O}$ fato de ter que sair de onde estão para ligar o computador justifica, para esses estudantes, o uso do celular.

Porque eu não vou abrir o computador pra ver um e-mail, já tá ali eu digito esse e-mail. Se não for alguma coisa que realmente tem que ser longa, um texto grande, um trabalho no Word, se for um e-mail de dois parágrafos eu mando ali logo, uso o celular mesmo. (EXT2)

Às vezes eu tenho preguiça de abrir o computador porque tô com o celular mais perto, tô com o celular no bolso. Aí eu tô no meu canto e tenho que me deslocar para poder ir ao computador, entendeu? Mesmo até com o notebook, porque tem que tirar o cabo da impressora. Eu opto pelo celular em vez de ter que levantar, às vezes eu tô estudando num canto e preciso de uma tela maior. Não, vou fazer no celular porque já tô no meu cantinho, já tô ali, e é mais prático. (EXT4) 
Assisto porque é mais fácil o acesso, botou o fone, tô ali na telinha. Até ligar o notebook pra assistir um vídeo... Assisto muito mais pelo celular mesmo. Até vídeo pra entretenimento, mas pro estudo também. Às vezes eu tô no quarto, onde o notebook tá, mas pego o celular, boto o fone, tô lá. (EXT11)

Até em casa mesmo às vezes não tô a fim de ligar o computador, alguma coisa assim, aí eu abro o celular na minha cama, leio, levo caderno e anoto as coisas. (HUM5)

As falas remetem aos rituais que eram exigidos antes das mídias móveis e das redes sem fio (SANTAELLA, 2013), em que os indivíduos precisavam estar em um ponto fixo, ligar o equipamento e aguardar a conexão para então navegar na internet. Hoje, ao contrário, basta alcançar um dispositivo que normalmente já está ligado e em condições de ser utilizado para realizar a atividade com apenas poucos toques ou arrastar de dedos nas telas touchscreen.

\begin{abstract}
A emergência das mídias móveis dotadas de conexão aboliu os rituais, instaurou a hipermobilidade e dissipou a dicotomia, infelizmente ainda renitente, entre real e virtual. De qualquer lugar, em qualquer momento, no movimento dos afazeres cotidianos, a entrada e saída do ciberespaço tornou-se ato corriqueiro. (SANTAELLA, 2013, pp. 135-136).
\end{abstract}

\title{
4.3.2.2.
}

\section{Usos em sala de aula}

No fim de 2017, o Ministério da Educação francês anunciou a proibição do uso do celular em escolas de ensino fundamental e médio não apenas em sala de aula, onde já não era permitido, mas também nos intervalos e durante os horários de refeição (ROCHA, 2017). Na direção contrária, estados e municípios brasileiros, como São Paulo e Minas Gerais, têm revertido leis que proíbem o uso do dispositivo e liberado sua utilização em atividades pedagógicas no ensino básico. Este é apenas um exemplo de que não há consenso sobre o tema, principalmente quando se trata de crianças e jovens. No ensino superior, porém, há maior flexibilidade na permissão de uso por parte dos estudantes.

$\mathrm{Na}$ Unirio não existe normativa institucional que regulamente a utilização de dispositivos móveis de comunicação, ou seja, cada professor tem autonomia para 
definir as regras em sala de aula. Conforme os relatos da maioria dos entrevistados, os docentes não estimulam o uso do dispositivo, à exceção de consultas à internet sobre determinado assunto, mencionadas algumas vezes. Um estudante das Exatas citou uma situação em que o professor deixou que os alunos fizessem consultas durante uma prova; outro, de Humanas, lembrou de uma saída para fazer registros fotográficos no entorno da universidade; e três discentes, também de Humanas, comentaram sobre atividade desenvolvida numa disciplina, em que o grupo teve que preencher um formulário em sala de aula, via celular, e o professor apresentou os resultados em tempo real.

Alguns entrevistados relataram situações em que professores da instituição proibiram ou reclamaram do uso durante a aula, e quase todos admitiram que utilizam o celular em sala - apenas dois estudantes disseram desligar ou somente checar a hora. Entre aqueles que disseram utilizar em atividades voltadas ao estudo, as justificativas para a prática em sala foram: consultar materiais armazenados no celular, na nuvem ou em outras plataformas; acompanhar na tela a leitura de um texto; utilizar ferramentas específicas (como aplicativos e, no caso dos estudantes das Exatas, calculadora); fazer pesquisa na internet; registrar em áudio ou em fotografia o conteúdo da aula.

Por outro lado, metade dos estudantes admitiu fazer também uso indevido do celular em sala de aula. Houve diferença entre as áreas do conhecimento: a maioria dos estudantes das Exatas (nove entre 12) reconheceu que utiliza o celular para fins não relacionados diretamente ao assunto tratado na aula. No caso dos estudantes de Humanas, apenas um (do total de oito) disse utilizar o celular para se distrair durante a aula; os demais afirmaram desligar ou utilizar o dispositivo somente em situações ligadas ao conteúdo trabalhado.

\footnotetext{
Assim, tem vezes que eu sei que eu deveria estar prestando mais atenção e não tô. Eu mesmo me sinto às vezes, por estar fazendo outra coisa no celular, me desviando do foco da aula, entendeu. Então eu acho que talvez o celular durante a sala de aula não seja o ideal, mas já acontece tanto que pra mim já virou natural, pro professor já virou natural. (EXT2)
}

Entre os motivos alegados para o uso inadequado do celular na sala de aula estão o entendimento de que a aula é "desinteressante" e "não está sendo produtiva" ou de que o assunto é "complicado", "algo que sei que não vou usar" e "não vejo 
muita vontade de aprender". Alguns estudantes justificaram que usam quando já viram ou sabem a matéria, ou porque precisam adiantar um trabalho de outra disciplina, por exemplo. Em certos casos, há a percepção de que o estudante não está em condições de prestar atenção no tema abordado, por questões pessoais. No entanto, todos os entrevistados reconheceram - por experiências pessoais ou na observação de colegas - que o celular atua como fator de distração. Alguns aspectos relacionados à atenção serão discutidos com mais detalhes na seção 4.3.4.

\subsection{3.}

\section{Percepções sobre o uso}

Uma das questões do protocolo de entrevista indagou diretamente se os estudantes percebiam diferenças no estudo e na aprendizagem em decorrência do uso do celular. Os dados produzidos a partir das respostas a esta pergunta, e a outros comentários feitos pelos entrevistados, foram organizados sob a categoria "Percepções sobre o uso", que se relaciona com outro objetivo específico deste estudo: Analisar as percepções de ganhos obtidos nos usos identificados.

De algumas falas, é possível inferir percepções conectadas a aspectos cognitivos e emocionais, como melhorias na capacidade de organização e na criatividade. Mas a maior parte das percepções de ganhos está relacionada ou coincide com as motivações para o uso; muitas respostas correspondem ao que foi apontado como justificativas para a utilização. A possibilidade de estudar em qualquer lugar e a qualquer hora, por exemplo, é vista de forma bastante positiva pelos estudantes, ainda que apontem dificuldades técnicas do celular (tamanho da tela, funcionalidades reduzidas etc.), e para alguns deles contribui com a aprendizagem. Acessar mais conteúdos, comunicar-se mais rapidamente e conseguir elucidar dúvidas durante a prática de exercícios também foram apontados como ganhos pelos entrevistados. Já os prejuízos estão principalmente relacionados à questão do celular como fator de distração e à dependência do uso. As duas próximas seções abordam algumas destas percepções. 


\subsubsection{1}

\section{Vantagens e ganhos}

Dos 20 entrevistados, sete apontaram o acesso à informação e a conteúdos diversos como principal vantagem do uso do celular para o estudo, e cinco destacaram a presença constante do dispositivo e o fato de poder utilizá-lo a qualquer momento, em qualquer lugar. Também foram elencadas como vantagens a possibilidade de comunicação rápida, a praticidade e a portabilidade.

Com relação ao que percebem como ganhos, a troca de informações e conteúdos, a interação e a colaboração é uma realidade para os entrevistados, principalmente com o uso do WhatsApp para resolver questões e dirimir dúvidas em tempo real. Alguns estudantes identificam ganhos advindos dessa relação mediada pelo celular, para compreender melhor algum tópico da disciplina e para avançar na resolução de um exercício, a qualquer tempo, onde quer que esteja. $\mathrm{O}$ entendimento dos processos utilizados para chegar à resposta correta durante a resolução conjunta de exercícios foi ressaltado por alguns estudantes das Exatas como um dos ganhos objetivos, em termos de aprendizagem, da utilização do dispositivo móvel.

Com certeza tem efeito. Eu vejo que, com o grupo do WhatsApp, as pessoas ficam mais conectadas com o conteúdo. E você tem um grupo com as informações em tempo real. Claro, tudo depende de uma demanda. Hoje, na turma de Física, das 10 pessoas que estão de Matemática lá, nove estão pra se formar agora ou pro ano. Então é algo que te estimula a correr atrás do conteúdo. Se faltar, se chegar atrasado, isso estimula a aprendizagem também. Porque a pessoa vai dali estudar pelo telefone, vai em cooperação ali mandando os exercícios que ela tenta, tira as dúvidas. Tem um professor, que é aluno do curso, no nosso grupo hoje, tá ajudando bastante. (EXT7)

Acho que faz bastante diferença. Como falei, você pode ver a qualquer hora, então se bater uma dúvida e você tá estudando, tá no meio da aula, não tá no computador, você pega o celular e vê ali na hora. É muito fácil, muito tranquilo estudar, não tem desculpa pra não estudar, só se não tiver o celular. Facilita muito sua vida, pra fazer uma consulta ou trabalhar ali com o exercício. (EXT10)

A possibilidade de buscar um conteúdo durante a aula, assistir a um vídeo ou usar um aplicativo e conseguir um melhor entendimento da matéria - e com isso, 
favorecer a aprendizagem - foi outro ponto relacionado pelos estudantes no que se refere às diferenças percebidas com o uso do celular. As passagens em seguida dão alguns exemplos destas visões:

Eu não conseguia estudar, porque eu não gostava de química, não gostava de história, geografia, não gostava dessas coisas. E foi o celular que me ajudou, a internet na verdade foi que me ajudou a gostar disso. Eu entendi melhor, porque às vezes tinha um vídeo que era mais fácil ver do que ter que digerir um texto de 600 páginas. Eu ficava mais tranquilo e aprendia mais. (EXT5)

Eu tenho acesso muito rápido a muitas coisas, então isso com certeza facilita o meu aprendizado. Se, toda vez que eu tivesse uma dúvida, fosse vir aqui na biblioteca, pegar o livro, procurar um bom, pra depois levar pra casa e estudar ia demorar um tempo maior pra eu aprender certos conteúdos. (EXT8)

A professora tá lendo um termo, fala algum termo que eu desconheço. Você atrapalhar uma leitura pra perguntar o que significa às vezes é complicado. E esperar até o final você perde a informação. Então rapidamente eu pesquiso, vejo o que significa aquele termo que o professor usou, que eu não faço ideia do que seja, e consigo compreender o restante da frase caso aquele termo seja determinante. (HUM3)

Embora poucos estudantes tenham mencionado que registram em foto o conteúdo anotado no quadro ou apresentado em slides pelos professores ${ }^{25}$, alguns apontaram essa prática como possibilidade de ganho na aprendizagem, uma vez que permite prestar atenção na fala do professor sem se preocupar em copiar as informações passadas em aula.

Tirar foto do quadro eu acho que ajuda muito, porque eu consigo absorver muito mais matéria durante a aula. Consigo prestar atenção na aula e absorver a matéria, pra entender e não chegar em casa com dúvidas. E na hora em que eu olhar a foto eu só vou precisar me lembrar daquilo que eu já aprendi. Quando eu copiava, tinha o caderno bonitinho, eu ficava me preocupando com cores, porque aí eu quero ter um caderno bonito, e me preocupava com qual cor eu vou usar agora. Ficava me preocupando em copiar do quadro em vez de escutar o professor. Porque, aí é meu, eu não consigo prestar 100\% de atenção no que

25 Alguns estudantes disseram que não costumam fazer registros fotográficos do quadro por saberem que não vão acessar posteriormente aquele conteúdo. A mesma justificativa apareceu algumas vezes sobre gravação em áudio das aulas. 
o professor está falando e escrever. É 50-50 e olhe lá, isso quando não presto mais atenção na escrita. (EXT9)

Hoje, devido a muitas preocupações na cabeça, ou eu paro pra ouvir a pessoa ou copio o que tá ali, eu não consigo fazer as duas coisas ao mesmo tempo. Quando era mais nova eu conseguia, a professora tava lá e eu estava copiando, escutando, tava atenta, mas hoje em dia não consigo muito. Se eu parar pra ouvir a explicação, acabou de explicar ele já vai lá no quadro apagar, então eu capturo aquilo ali pra depois não perder. Aí quando eu volto a estudar aquilo, vou lembrar 'ah, ele falou disso aqui assim assim'. Se eu não tiver, aí eu me perco, tenho que buscar lá no livro, na apostila... E às vezes ele dá macetes no quadro que no livro ou na apostila não tem. Em vez de sair correndo pra copiar eu vou e já bato a foto. (EXT12)

Houve também menção a melhorias na capacidade de organização:

Acho que eu fiquei muito mais organizada. Pelo aplicativo de tarefas que eu olho todo dia no celular, ou pelo aplicativo de notas que eu tenho, acho mais fácil lembrar da matéria, tenho tudo armazenado no celular e no computador. (EXT1)

Embora percebam ganhos do uso no transporte público ou em ambiente externo, dois estudantes analisaram de forma crítica a qualidade do estudo:

Não vou dizer que é a mesma coisa, não é a mesma coisa. Mas se eu consigo fazer, me habituei a fazer? Sim, me habituei a fazer em lugares públicos já. Estudar, ler, fazer trabalhos. No trabalho eu tenho um computador, eu já fiz trabalhos de Power Point. (EXT2)

Assim, eu percebo que o tempo de estudo que eu tenho no trem não tem a mesma qualidade do estudo que eu tenho em casa, que o estudo que eu tenho aqui [Unirio], sabe? Mas eu consigo lidar, consigo utilizar esse tempo pra melhorar os estudos. Consigo algum resultado. Não posso contar exclusivamente com isso, mas é um auxílio. (EXT3)

As percepções mais explícitas de ganhos de natureza cognitiva vieram de estudantes de Pedagogia, o que pode indicar uma reflexão baseada em conhecimentos prévios relacionados ao curso.

Cognitivamente eu não vejo muita diferença, porque são plataformas parecidas, diferentes mas parecidas, e o objetivo acaba sendo o mesmo, que é me trazer informação. Ele [o celular] não vai me trazer conhecimento, conhecimento sou eu 
que vou produzir. Ele vai me trazer informação, o dado, que aí eu vou trabalhar e transformar em conhecimento. Talvez até venha um conhecimento com a informação, 'nossa, não sabia disso, pronto, gerou um conhecimento'. Mas pode ser ali, pode ser um jornal, pode ser uma revista, pode ser a televisão, no noticiário, uma informação numa entrevista. Então ele é mais uma plataforma que auxilia e que facilita o aprendizado. Mas não é a única. (HUM2)

Percebo diferença na questão da criação. A criatividade, quando a gente está muito preocupado com escrever, a próprio punho, a gente está ali fazendo uma ligação entre nosso cognitivo e nosso físico. Porque, como já havia dito, a escrita a próprio punho cansa até um determinado ponto. $\mathrm{O}$ digitar no celular não cansa tanto, então a gente consegue ter um momento mais profundo e concentrado consigo mesmo, e mais a fundo no estudo, e consegue ter uma produtividade mais potencializada. Eu vejo isso como fundamental e influencia diretamente na minha aprendizagem. Porque eu consigo ter um contato mais concentrado. Mas isso sou eu, cada um vai ter uma relação diferente. (HUM4)

Percepções positivas do uso de dispositivos móveis em atividades de estudo estão também presentes em pesquisas empíricas apresentadas no capítulo 2 e outras (ALSADOON, 2012; KAIESKI; GRINGS; FETTER, 2015; ORGANISTA; SANTOYO, 2015), com destaque para ganhos advindos da mobilidade (acessar conteúdo, estudar e aprender em horas e lugares à escolha do aluno), da portabilidade e das oportunidades de interação e colaboração.

\subsubsection{2.}

\section{Desvantagens e prejuízos}

Embora os entrevistados apontem vantagens e percebam ganhos relacionados à utilização do celular em atividades de estudo, durante as conversas emergiram algumas percepções negativas dessa prática. Entre elas, o comodismo frente à busca de conteúdos que não estão facilmente disponíveis na internet; a possibilidade de ruídos na comunicação, que podem prejudicar o entendimento; o excesso de informação que pode ser acessada e que é discutida nos grupos e redes sociais; cansaço e danos à saúde dos olhos, devido à leitura na tela. Cabe ressaltar que essas visões foram compartilhadas tanto por estudantes que usam o celular com mais frequência como por aqueles que afirmam utilizar pouco. 
A questão de dependência ou vício foi apontada por alguns estudantes como uma das desvantagens do uso do celular em atividades relacionadas ao estudo. Outra percepção negativa, no entanto, se destacou nos relatos: o reconhecimento do celular como fonte de distração ou possibilidade de fuga de determinadas situações. Apontado, pelos entrevistados, como principal desvantagem do uso, este será um dos aspectos discutidos na próxima seção, que aborda com mais detalhes o tema da atenção.

\subsection{4}

\section{Atenção}

Os impactos do uso de tecnologias digitais de informação e comunicação em funções cognitivas como memória e atenção, entre outras, têm sido objeto de reflexões teóricas e investigações experimentais (SANCOVISCHI; KASTRUP, 2013; SILVA; SILVA, 2017, para citar alguns) em diferentes campos do conhecimento. Na revisão de pesquisas empíricas, algumas delas (ALSADOON, 2012; GIKAS; GRANT, 2013; ALCALÁ, 2017, entre outros) mostraram a distração como principal ponto negativo citado por universitários que utilizam dispositivos móveis em atividades de estudo.

Este panorama motivou a inclusão de questões, no protocolo de entrevista, para verificar se os estudantes percebem diferenças com relação à atenção quando utilizam o celular em atividades de estudo e como lidam com possíveis distrações, entre elas as notificações que aparecem na tela e a possibilidade de iniciar facilmente outra atividade não relacionada à original. $\mathrm{O}$ assunto, entretanto, apareceu também espontaneamente na maior parte das entrevistas. A seção 4.3.3.2 (Desvantagens e prejuízos) apresenta falas que apontaram o reconhecimento do celular como fonte de distração ou possibilidade de fuga de determinadas situações como a principal desvantagem do uso do dispositivo para estudar. Tais percepções, em conjunto com os resultados similares das pesquisas mencionadas, podem indicar que os estudantes identificam situações e condições que afetam, positiva ou negativamente, sua relação com o conhecimento acadêmico. Entre elas, a distração ou a dispersão potencializadas pelo acesso rápido e fácil ao "mundo exterior", por meio do dispositivo de comunicação que têm à mão. 
Cabe observar que o conceito de distração aqui adotado é o de Kastrup (2004, p.8): trata-se de uma ação em que "a atenção vagueia, experimenta uma errância, fugindo do foco da tarefa para a qual é solicitado prestar atenção e indo na direção de um campo mais amplo [...]". A autora ressalta que esse campo pode ser habitado por diferentes pensamentos, percepções, reminiscências, objetos e ideias, todos eles resistentes à tarefa original. Já a dispersão consiste "num repetido deslocamento do foco atencional, que impossibilita a concentração, a duração e a consistência da experiência" (KASTRUP, 2004, p.8).

Como descrito anteriormente, no que se refere ao uso em sala de aula uma parte dos entrevistados reconhece utilizar o celular em situações não relacionadas ao que está sendo abordado pelo professor ou colegas. Dourado (2015) reflete sobre as dispersões que acontecem durante as aulas com o uso do celular e conclui que o dispositivo potencializa tais atitudes, que não são características apenas da atualidade.

Sabe-se que sempre houve as "dispersões" [grifo da autora], as ausências físicas ou psicológicas por parte dos alunos durante as aulas. A diferença existente entre a dispersão do aluno na atualidade e antigamente deve-se à possibilidade de interatividade com indivíduos que não estão estabelecidos no mesmo ambiente que ele. Nesses momentos, o celular representa um vetor para a ausência sem haver necessidade de se retirar da sala. (DOURADO, 2015, pp. 97-98)

Nos relatos dos entrevistados, nota-se que há situações distintas em que a atenção se desfoca pelo uso do celular: uma em que o estudante recorre ao dispositivo sem intenção de se distrair, para fazer alguma atividade relacionada à aula ou consultar a hora, por exemplo, mas acaba por utilizar outros recursos - o que motivou neste estudo a criação da subcategoria "Celular como fonte de distração". A outra situação é quando o estudante apela ao dispositivo como alternativa a alguma situação entediante ou desinteressante - seja uma aula ou a leitura de um texto -, ou quando ele é afetado por questões pessoais e não tem condições de se dedicar à atividade de estudo. Para estes casos, foi criada a subcategoria "Celular como possibilidade de fuga". As próximas seções analisam relatos que se referem a estas situações e mencionam estratégias utilizadas para evitar ou minimizar os fatores de distração. 


\subsubsection{1. \\ Distração e fuga}

Os dispositivos móveis de comunicação aliam recursos de voz, texto, foto e vídeo à conexão em rede e à mobilidade pelo espaço físico e o ciberespaço (LEMOS, 2007), com inúmeras opções de uso. Greenfield (2011) enumera os principais fatores que tornam as mídias digitais atrativas: abundância e disponibilidade de conteúdos; facilidade de acesso; estruturas de reforço e recompensa (jogos, conteúdos sexuais, compras etc); aspectos relacionados à interação social; familiarização com os ambientes digitais de crianças e jovens (Fatores Gen-D ou Generation-Digital).

A pesquisa TIC Domicílios 2016 listou as 14 atividades mais realizadas por usuários de telefone celular no Brasil: fazer e receber chamadas telefônicas; tirar fotos; mandar mensagens; ouvir música; assistir a vídeos; compartilhar fotos, vídeos ou textos; usar redes sociais; buscar informações; enviar mensagem de texto (SMS); acessar páginas ou sites; baixar aplicativos; enviar ou receber e-mails; jogar; usar mapas. Não é difícil imaginar que essas tantas e outras possibilidades sejam fatores de distração durante a realização de atividades de estudo com o celular, especialmente quando estão aliadas a recursos que atraem a atenção para os aplicativos, como as notificações do WhatsApp e do Facebook, para mencionar os exemplos mais citados pelos estudantes, organizados na subcategoria "Celular como fonte de distração".

Uso geralmente pra ver hora, por exemplo, aí você acaba vendo que tem mensagem nova. Aí de uma mensagem passa pra outra. Geralmente é essa desculpa de ver hora. Ou às vezes vou ver se o cara respondeu, porque mandei uma mensagem de manhã e é importante. [...] Se eu sei que a aula é importante, tô acompanhando ali, aí geralmente eu não largo, fico no celular mas fico com um olho cá e outro aqui. Mas se tá chata, tediosa, ou o que tô fazendo no celular é mais importante, aí eu desligo total, fico só no celular. (EXT6)

Acho que eu poderia ser muito mais centrado na hora que eu tô com o telefone. Porque eu até tô pesquisando sobre a minha área, tô fazendo algum estudo relacionado, só que "popa" uma janela do WhatsApp eu jogo pro lado. "Popa" duas vezes eu jogo pro lado. "Popa" na terceira vez, 'ah, rapidinho, deixa ver o que é'. Isso sete horas da noite, daqui a pouco são nove e eu já esqueci qual página estava aberta no navegador do meu estudo. (EXT7) 
Por exemplo, eu tô vendo um vídeo, mas chega uma notificação das minhas amigas eu vou, abro e fico conversando com elas. $\mathrm{Ou}$ então alguém me liga e eu fico lá no telefone, deixo o vídeo de lado. Eu consigo me distrair muito rápido, então acabo perdendo tempo que eu não tô estudando, tô fazendo outra coisa. (EXT8)

Por mais que eu esteja utilizando focado naquele texto, vai aparecer uma coisinha e você já pensa, o que pode ser? Isso tenta você. Eu tô lendo o texto, eu tô vendo o vídeo, mas aí aparece uma notificação. Eu vou ficar tentado a ir lá. Esse autocontrole, que eu até consigo ter, não digo pra você que sou um santo ou que sou $100 \%$, mas em $80 \%$ dos casos eu consigo. (HUM2)

Acho que perde o foco, realmente. Porque quando você está no celular, você não vai ver só aquilo que você está pretendendo fazer. Vai chegar mensagem, notificação, aí você vai dar um descanso, vai pra um aplicativo qualquer, e aí você fica horas e horas e horas. Você pega pra fazer uma coisa na rede social e fica horas. [...] Porque você começa lendo, aí vai fazer outra coisa, depois outra coisa, quando vê você esqueceu da sua tarefa primária, que seria estudar, e aí acabou. Você se desliga do universo a sua volta, das outras coisas que tinha que fazer, por exemplo um trabalho, um fichamento, e acaba meio que se perdendo. (HUM4)

As falas dos entrevistados remetem à falta de controle e à perda de autonomia no uso dos recursos disponíveis no celular. Os estudantes transitam quase que involuntariamente entre uma atividade e outra; vão do foco no estudo às conversas no WhatsApp ou ao uso de um aplicativo, vistos como "tentação"; deixam-se levar pelos atrativos do celular e, segundo alguns relatos, muitas vezes é difícil retornar ao ponto original. Nestes casos, os jovens reconhecem que há um prejuízo nas atividades de estudo devido à distração propiciada pelos atrativos de seus dispositivos móveis.

Além da distração involuntária, há circunstâncias em que o estudante recorre deliberadamente ao celular durante a atividade de estudo (subcategoria "Celular como possibilidade de fuga"). É o caso de aulas ou assuntos considerados desinteressantes ou desestimulantes; quando o estudante tem facilidade ou já sabe a matéria; ou, ao contrário, quando considera o assunto muito difícil. Nessas situações, o aluno decide usar o tempo para se distrair no celular e vai à procura de algo que considera mais interessante ou produtivo. 
Às vezes eu já estudei algumas matérias, não consegui cortar e eu sei aquela matéria, já sei como funciona, às vezes eu só quero pular. Aí ou eu fico no celular fazendo coisa ou vou aprofundar com o celular a matéria dele. Lazer só quando eu sei a matéria e já não vejo mais necessidade de me aprofundar nela. Quando é algo que eu sei que não vou usar ou que não vejo muita vontade de aprender, aí geralmente é lazer. Fico no Facebook, ou então desenhando alguma coisa. (EXT5)

O bom é estudar bem antes da prova, porque você tem tempo de estudar a matéria toda. Se eu for estudar um dia antes, não vou conseguir. Vou ser interrompida mesmo, vou me distrair mesmo, não vou conseguir prestar atenção naquilo. É difícil voltar. Sei lá, tem alguém querendo conversar com você, e estudar é chato, é difícil. Um negócio que você não está entendendo, então voltar praquilo é complicado. Mas tem que voltar. (EXT8)

É desesperador, você olha e vê que não sabe nada. Mas são matérias que você chega em casa, vai estudar e aí entende perfeitamente. Normalmente é nessas horas, ou então quando tem algum aluno discutindo com professor, eu não participo, vou pro joguinho de paciência. Ou então em matérias que eu já sei o conteúdo. Eu reprovei em cálculo semestre passado sabendo a matéria, então esse semestre as aulas são excruciantes pra mim, porque eu já sei. Então aí eu apelo. Eu quero estar ali presente pra caso eu ouça alguma coisa nova, pra que eu esteja a par do que tá acontecendo na aula. Mas ao mesmo tempo eu vejo que não tem necessidade de eu ficar prestando $100 \%$ de atenção. Então fico só ouvindo e jogando. (EXT9)

Uso pra ler texto ou de vez em quando, quando tô de saco cheio da aula. [...] Quando eu tô desinteressada da aula, não tô conseguindo focar, aí vou mexer em outra coisa, converso com alguém... Às vezes até quando tô conversando acabo ouvindo alguma coisa que acho interessante e falo 'opa, vou prestar atenção nisso', aí pego o caderno e anoto. (HUM5)

Uma das críticas que se faz à escola - e que vale para todos os níveis de ensino - é que ela não consegue acompanhar as transformações do mundo contemporâneo, em que os saberes não estão mais concentrados naquela instituição. Em entrevista ao jornal Correio Braziliense, o educador português José Pacheco aponta para uma contradição presente no paradigma atual de educação, relacionada à tríade professor-aluno-escola: "Esse modelo que temos com alunos do século 21, com professores do século 20, a trabalhar com um modelo do século 19, não resulta. O que está em debate é o modelo educacional, que vem da revolução industrial" (CHAIB, 2016). Charlot (2013) ressalta que a sociedade contemporânea exige dos cidadãos e consumidores uma postura reflexiva, crítica, criativa, mas tem na escola um espaço de práticas que não estimulam o desenvolvimento dessas competências. 
Um aspecto destacado pelo autor, e que se relaciona com a crítica à escola tradicional, é o fato de os alunos não encontrarem sentido no que fazem dentro do espaço escolar, nem conexão do que estudam com seus cotidianos e suas culturas: “[...] há cada vez mais alunos que vão à escola apenas para passar de ano e que nunca encontraram o saber como sentido, como atividade intelectual, como prazer." (CHARLOT, 2013, p. 21). Sibilia (2012, p. 197) retrata a escola como uma "máquina antiquada", com "seus componentes e seu funcionamento cada vez mais conflitantes com nossos jovens".

[...] em face às fortes transformações ocorridas nas últimas décadas, não surpreende que a escola tenha se convertido em algo terrivelmente chato, e que a obrigação de frequentá-la signifique uma espécie de calvário cotidiano para as dinâmicas e interativas crianças contemporâneas. (SIBILIA, 2012, p. 206)

Tais perspectivas dialogam com os relatos de alguns entrevistados, no que se refere ao tédio e ao desinteresse manifestados em relação a algumas aulas e a determinados conteúdos. O incentivo a um sistema de trabalho colaborativo, em que os estudantes compartilhem conhecimentos e experiências com seus pares, pode ser um modo de minimizar tais situações. No caso do estudante que cursa a disciplina pela segunda vez, por exemplo, ele poderia atuar como tutor para os colegas iniciantes na matéria, dividindo o que já sabe com os demais e, consequentemente, aprendendo mais - o que, talvez, estimulasse seu interesse pela disciplina.

Assim como há situações de uso do celular por desinteresse e tédio frente às atividades de estudo, alguns entrevistados mencionaram que fazem uso deliberado do dispositivo quando são afetados por questões pessoais e, por isso, não têm condições de dedicar atenção ao estudo, como exemplificam as falas a seguir (também organizadas na subcategoria "Celular como possibilidade de fuga"):

É realmente quando eu tô com meu emocional meio balançado, por conta de alguns estresses. Aí às vezes tem muita coisa pra fazer, eu fico meio 'ai, não sei o que faço agora'. Aí às vezes eu tô numa aula, que deveria estar prestando atenção, mas aí às vezes eu tô pensando em outra coisa. Ou então estou em um lugar em que eu não queria estar e aí... Mesmo sendo uma coisa importante, que eu deveria estar prestando atenção. Se eu não estiver bem então acabo recorrendo ao celular, pra fugir da situação mesmo. É uma outra coisa, você com o celular na mão 
você consegue sair de situações quando você quiser. Realmente, né, você consegue se desligar de algum lugar assim. (EXT3)

Eu tenho completa consciência de que eu tenho me distraído, mas tem dias que eu tô querendo que todo mundo exploda, que o professor se exploda e aí eu não falo, vou ficar na minha, aí vou pro meu telefone, pra jogar assunto fora e ver se eu vou relaxando. [...] Tem dia que eu chego mega abatido do trabalho, aí eu chego na sala de aula e vejo que não vou ter condições de prestar atenção em nada e aí às vezes eu fico no telefone. (EXT7)

Nestes casos, o foco do pensamento desde o início já não está na atividade de estudo, mas sim em algum problema ou situação difícil enfrentada pelo estudante. Os atrativos do celular, então, são acionados e servem para desanuviar o pensamento, aliviar o estresse, fazer esquecer o mal-estar e as experiências negativas da vida. Abreu et al. (2008) apontam a internet como um dos recursos utilizados por usuários com vulnerabilidade pessoal para diminuição do estresse e do medo da vida real, e acreditam que,

[...] à medida que esses internautas se refugiam progressivamente no mundo virtual e se aliviam das experiências de vida, tais comportamentos começam a exibir características muito mais peculiares e intensas daquelas inicialmente apresentadas. Portanto, nesse momento passariam a assumir uma nova forma de classificação psiquiátrica - a então denominada dependência de internet. (ABREU et al., 2008, p. 165).

Seja deliberadamente ou não, o que se observa nas falas dos estudantes é que o celular facilita a transferência de foco do estudo para outros interesses. Neste sentido, Sancovschi e Kastrup (2013) constataram uma fronteira tênue entre atividades de estudo e de entretenimento realizadas com o uso de tecnologias digitais, com trânsito frequente de uma para a outra. As autoras acreditam que essas tecnologias mobilizam um tipo de atenção que salta entre focos distintos, sem que haja desvio - ou seja, um modo de estudo do tipo saltitante e uma atenção que não é plena, mas suficiente para dar conta da atividade principal. Alguns aspectos relacionados ao manejo da atenção pelos participantes da pesquisa estão descritos na próxima seção. 


\subsubsection{2}

\section{“Eu simplesmente tiro": o manejo da atenção}

Frente ao potencial de distração que o celular apresenta, parte dos entrevistados relatou adotar estratégias para minimizar os possíveis efeitos negativos dessa distração. Entre elas, desligar o aparelho, a conexão wi-fi e/ou dados móveis; desabilitar notificações de aplicativos, jogos e outros recursos; manter o dispositivo em modo avião (em que não é possível conectar-se à internet ou fazer chamadas). Outros estudantes, porém, afirmaram que conseguem lidar com as interrupções provenientes do celular, durante uma atividade de estudo, sem utilizar estratégias específicas. Esses relatos foram organizados na subcategoria “Estratégias de manejo da atenção", e alguns deles estão transcritos a seguir.

Isso é chato às vezes. Eu tô lendo e aí desce um negócio ali do WhatsApp, é chato. Mas assim, quando a parada tá urgente mesmo, eu tenho que fazer, eu consigo... [...] Consigo só chegar pro lado, tirar a notificação e continuar lendo. Mas só o fato de chegar pro lado já gera um break. É chato, mas também acho que é aquele negócio, eu já me habituei. [...] Acho que deve me atrapalhar um pouco eu perder, voltar na frase, mas é que nem o barulho externo. Teria um modo melhor? Teria, mas assim, eu faço, bola pra frente. (EXT2)

Normalmente, se eu vejo que é um texto muito técnico, que eu preciso prestar uma atenção maior, eu vou ler e deixar pra lá as notificações, vou tirar a notificação da minha tela, toda hora que entrar eu vou tirar. Ou vou avisar pras pessoas que eu tô estudando, vou fazer alguma coisa assim. Essa seria minha segunda opção quando o texto é dessa forma, denso, difícil, porque a primeira seria imprimir. Quando é um texto normal só pra aula, não precisa fazer nada sobre ele, não precisa entender tudo, só ler pra ter uma ideia do que vai falar na aula, eu leio de boa. Vem a notificação eu abro, respondo, volto pro texto. Fico nesse vai e volta e consigo entender bem. (EXT9)

Eu assisto do início ao fim. Às vezes tem notificação do próprio YouTube, sugerindo não sei o quê. Eu até olho mas nada que eu vá até lá, não me abala não. Eu continuo, ainda mais se o cara for muito descolado, me dá mais vontade de ficar ali. Até porque os vídeos são curtinhos, você ficar parando ali muito não dá muito certo. (EXT12)

Eu até lido bem com essa questão das notificações. Primeiro eu bloqueio todas as notificações instantâneas que eu consigo. WhatsApp é uma que eu não consigo, o Facebook é que fácil e possibilita isso, o WhatsApp ainda não possibilita, então a gente 
acaba recebendo. Por mais que a gente possa silenciar a notificação aparece. Eu simplesmente tiro, acho que é uma relação consigo mesmo, do comprometimento. Se você tá querendo ler e tem que ler, eu faço aquilo, aparecem as notificações e eu vou tirando, não vou dando atenção. (HUM4)

Os relatos indicam que os estudantes adaptaram suas atitudes frente ao que o celular impõe ao usuário. Há indícios de uma ação consciente: os estudantes que escolhem, por exemplo, não desabilitar as notificações do WhatsApp registram o momento em que elas aparecem, mas optam por continuar na atividade de estudo ("aparecem as notificações e eu vou tirando, não vou dando atenção"). Ou, no caso das videoaulas, percebem as sugestões de conteúdos na plataforma do YouTube mas não se deixam distrair até o fim da exibição do vídeo ("eu até olho mas nada que eu vá até lá, não me abala não").

Por outro lado, alguns estudantes relataram dificuldade para fazer essa transição sem perder o foco, e há quem perceba variações na capacidade de foco e na compreensão do conteúdo após eventuais interrupções ou desvios.

Não é fácil, porque quando você sai já se perde um pouco, de repente já tá no Facebook, já tá assistindo um vídeo de humor, de entretenimento, já não é mais estudo. Quando eu saio é muito mais difícil. Eu raramente saio, mas quando eu saio é difícil voltar. (EXT11)

Eu tenho um pouco de dificuldade de me concentrar na leitura, sou muito difícil de concentrar. Então às vezes eu preciso ler o texto duas ou três vezes pra pegar uma ideia, pra eu poder, sabe? Então essa é uma das formas pelas quais eu evito desviar, mesmo quando tem a tentação. Porque depois pra eu retornar é mais difícil. [...] Eu já tenho dificuldade de me concentrar. E aí quando você começa a mergulhar naquele universo, começa a entender, aí desfoca. (HUM2)

Às vezes me atrapalha, eu fico muito distraída. Mas como eu consigo prestar atenção em muitas coisas ao mesmo tempo, às vezes eu pego alguma coisa e acaba fluindo. Mas em geral eu me sinto um pouquinho atrapalhada. (HUM5)

Houve também relatos do que pode ser relacionado ao conceito de atenção dividida/distribuída, "quando as atividades realizadas envolvem órgãos do sentido ou habilidades diferenciadas, podendo ser executadas simultaneamente" (REGIS; TIMPONI; MAIA, 2012, p.8). Dois entrevistados, por exemplo, mencionaram que estudam ao mesmo tempo em que ouvem música, para atenuar os barulhos externos: 
Normalmente eu ainda tô ouvindo música enquanto eu tô lendo. Porque é mais fácil pra mim com a música do que com o barulho da rua em volta. [...] A buzina na rua me distrai, ali eu já sei tudo o que eu vou ouvir. Então eu boto no máximo e vou lendo, e vou fazendo anotações de margem no próprio aplicativo. [...] Tem pessoas que vão ter mais dificuldade, tem pessoas que não vão ter. Eu preciso voltar um parágrafo só e volta o fio da meada. (HUM1)

Acho que é uma questão também de foco. Eu costumo ler com música. Tenho uma caixinha de som bluetooth, então muitas vezes eu toco diretamente nas caixinhas, às vezes eu faço uso do fone de ouvido. [...] Quando eu perco o foco são coisas externas normalmente, um barulho, o cachorro latindo, minha mãe entra no quarto, são coisas mais externas assim que atrapalham meu foco. [...] Muitas vezes a gente acaba perdendo a página, isso acontece facilmente com esses aplicativos de rolagem. Aí tem uma certa perda, tem que retomar toda a ideia inicial do texto, iniciar a leitura de novo pra voltar a entender. É complicado mas a gente vai levando. (HUM7)

Formas de manejo da atenção foram descritas por Papadopoulos (2018) em estudo com universitários diagnosticados com Transtorno de Déficit de Atenção e Hiperatividade (TDAH). Os dados da autora mostram que os estudantes conseguem identificar suas dificuldades e suas formas de aprender para, a partir daí, desenvolver estratégias facilitadoras da aprendizagem, de modo similar àquelas descritas por alguns estudantes entrevistados para esta dissertação, não diagnosticados com TDAH. Nesse sentido, Bannell et al. (2016, p.71) defendem que a capacidade de alternância entre foco e distração em intervalos de tempo mais curtos pode não ser resultado de distrofias no manejo da atenção, mas uma aprendizagem da atenção, propiciada pela experiência em contextos com grande fluxo de informações, que pode favorecer os indivíduos frente aos estímulos a que estão expostos.

\subsection{5}

\section{Exatas x Humanas}

Uma das questões propostas para esta investigação relacionava-se à possibilidade de haver semelhanças e diferenças de usos e de percepções dos 
estudantes das Ciências Exatas e das Humanidades. A suposição era que os de Exatas teriam mais interesse pelo uso de recursos tecnológicos e, portanto, usariam com mais frequência o celular e/ou explorariam mais funcionalidades disponíveis no dispositivo. Como mencionado anteriormente, o simples fato de mais estudantes dos cursos das Exatas terem aceitado participar da pesquisa pode indicar um maior interesse pelo tema, mas não é possível fazer tal afirmação sem investigar os motivos para anuência ou recusa.

Com relação ao uso cotidiano de celular, o Quadro 3 (disponível na seção 4.1) revela uma semelhança de hábitos entre os estudantes das distintas áreas em quase todas as atividades. Apenas no caso de ligações telefônicas houve uma variação maior de respostas: somente um estudante (entre 12 das Exatas) disse fazer ligações telefônicas muitas vezes na semana, e nenhum optou por todos os dias; dentre os estudantes de Humanas, três (entre oito) afirmaram usar o celular todos os dias para este fim. Porém, de modo geral, a utilização cotidiana mostrou-se similar entre os dois grupos.

Quanto às atividades de estudo, foram elencadas nas categorias anteriores algumas semelhanças e diferenças entre os estudantes dos dois campos do conhecimento. Entre elas, a utilização do WhatsApp por todos os entrevistados; a prática de resolver exercícios em grupo, mais comum entre os estudantes das Exatas; e o uso do celular em sala de aula para fins não relacionados a estudo, admitido pela maioria dos estudantes de Exatas e por apenas um de Humanas. Um dos entrevistados fez uma comparação entre o comportamento de estudantes das duas áreas:

Estudando pra prova, por exemplo, tem uma lista de exercícios e eu resolvi um exercício. Aí a pessoa tá na casa dela, e é como se fosse um grupo de estudos. Ela fala 'pô, você fez o exercício 2? Eu falo 'fiz'. 'Pô, manda uma foto aí pra eu ver', eu vou lá e mando. [...] Isso acontece bastante. Acho que principalmente em Exatas, que você tem uma metodologia de como fazer a questão, eu acho que... você falou do tema, de Exatas e Humanas, acho que em Exatas isso é muito recorrente. Porque se tem uma questão de planejamento e controle da produção ela tem uma resolução, uma só, X. Você conseguindo fazer a resolução passo a passo, e a outra pessoa pegando o que tá ali, ela consegue ver. Então com a foto, muitas vezes já vai. (EXT2) 
Num dos estudos encontrados na literatura acerca de hábitos tecnológicos de estudantes de diferentes áreas do conhecimento, González (2015) apresenta resultados de pesquisa sobre o uso de internet realizada com 196 jovens universitários da Universidade Nacional Autônoma do México - 82 da Faculdade de Filosofia e Letras (cursos de Letras e Pedagogia) e 114 da Faculdade de Engenharia (cursos de Engenharia de Computação e Engenharia Mecânica). A investigação, de caráter quantitativo, indicou diferenças de hábitos influenciadas pela área de conhecimento. $\mathrm{O}$ autor aponta, por exemplo, que os estudantes da Engenharia se interessam mais por atividades relacionadas a socialização, em comparação com os do campo da Filosofia e Letras.

É provável que isto se relacione ao fato de que os estudantes das Engenharias preferem o uso de dispositivos para se comunicar enquanto socializam, podem fazer outras coisas, ao contrário dos estudantes da Filosofia, que podem preferir o diálogo físico com as pessoas, centrando-se ou realizando outras atividades que não tenham a ver com as tecnologias. (GONZÁLEZ, 2015, p. 145)

Ainda que não seja possível fazer inferência similar a partir das entrevistas realizadas para esta dissertação, nota-se que mais estudantes das Ciências Humanas manifestaram preocupação com o tipo de relação desenvolvida nos meios digitais e com a ausência de contato presencial. Um dos estudantes expressou diretamente este sentimento:

Às vezes você esquece do mundo lá fora, acho que é outro problema que tá ocorrendo muito nessa era digital. Sei lá, você tá triste e às vezes meio que se isola, fica o dia inteiro vendo série, por exemplo. Eu acabo fazendo isso. Às vezes esquece de interagir com as outras pessoas, esquece que o contato pessoal, o contato físico é muito importante. (HUM5)

O estudo mexicano também apresentou diferenças entre as atividades específicas de uso da internet. A principal delas apareceu na opção 'baixar softwares' (31\% para estudantes das Engenharias contra 6\% para estudantes de Filosofia e Letras), o que sugere que os primeiros utilizam softwares mais especializados para seus trabalhos escolares (GONZÁLEZ, 2015). Este aspecto também foi observado entre os estudantes dos cursos de Exatas da Unirio, que mencionaram com mais frequência o uso de aplicativos específicos em suas 
atividades de estudo. Entre eles, apps de calculadora científica e de construção de gráficos 3D, com destaque para o software GeoGebra, mencionado por seis dos 12 entrevistados das Ciências Exatas.

\subsubsection{1}

\section{GeoGebra}

Utilizado para o ensino e a aprendizagem da matemática em todos os níveis de ensino, o GeoGebra é um software que possibilita criar gráficos e planilhas, resolver equações e analisar dados nas áreas de geometria e álgebra. As imagens 3 e 4 apresentam capturas de tela de um dos entrevistados, que mostram o menu de opções do aplicativo e um gráfico, com sua conformação em 3D, construído a partir de uma função dada pelo estudante.

Imagens 3 e 4 - Tela do celular de um dos entrevistados, com o aplicativo GeoGebra em uso
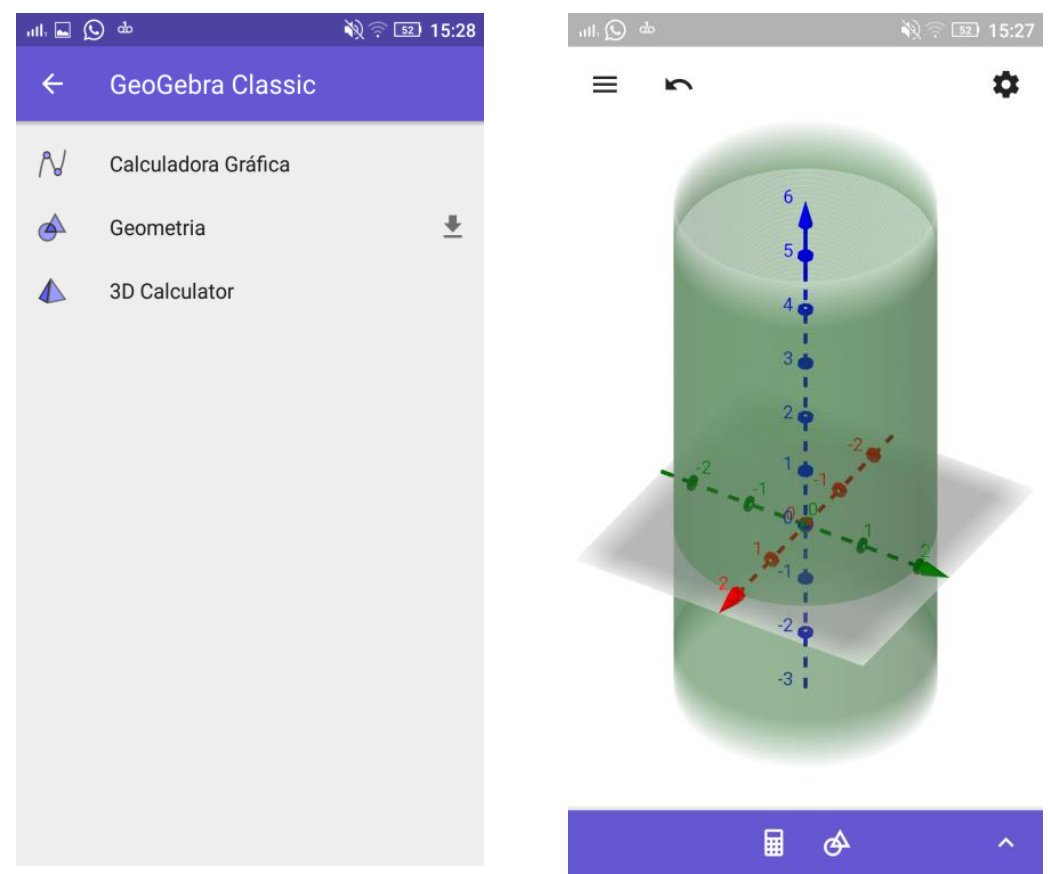

Fonte: Arquivo da pesquisa. 
O aplicativo tem sido objeto de estudos desenvolvidos no Brasil e no exterior. A I Conferência Latinoamericana de GeoGebra ${ }^{26}$, por exemplo, realizada em 2011, reuniu 99 trabalhos sobre o uso do software em sala de aula, práticas pedagógicas e relações com ensino e aprendizagem. Há conferências dedicadas ao tema nos Estados Unidos, Canadá, países nórdicos e bálticos, entre outros, e pelo mundo são mais de 500 institutos que desenvolvem projetos em rede com o aplicativo.

Estudos sobre o uso do GeoGebra como ferramenta pedagógica apontam que o app pode, entre outros pontos, proporcionar maior motivação, interesse e envolvimento dos estudantes nas atividades e discussões propostas (RICHIT et al., 2012); aguçar a curiosidade e ampliar a interação entre discentes e professores (LOPES; SANTOS, 2016); favorecer o desenvolvimento de competências matemáticas nos estudantes (SUPRIADI et al., 2014); e ser útil no processo de preparação de aulas e diversificação de tópicos abordados pelos professores (BUDINSKI, 2017).

Entre os aplicativos apontados pelos estudantes das Ciências Exatas que participaram desta pesquisa, o GeoGebra foi o mais citado. Mesmo aqueles que não utilizam o app no celular disseram conhecê-lo por meio de colegas ou professores. Aqueles que usam salientam que o aplicativo auxilia especialmente o entendimento de gráficos 3D, necessários para a compreensão de determinados tópicos da matemática e ciências afins. É o que indicam os relatos adiante:

O celular faz diferença, esse entendimento geométrico pra mim fica mais fácil. Não é que fica mais fácil, algumas coisas ficam mais compreensíveis [...]. Visualmente pro aluno se torna mais atraente do que fazer vários desenhos, e às vezes fica muito confuso, porque nem sempre o desenho é perfeito. Um desenho 3D no quadro não é tão simples assim, não é todo mundo que consegue enxergar um cubo num quadro plano. (EXT4)

Por exemplo, em cálculo, você estuda muitas funções e de repente você até sabe como é a função mas não sabe como é o gráfico dela, que forma ela vai fazer. Você põe no aplicativo e tem uma ideia melhor do que tá falando, porque você tem o desenho do gráfico daquela função. Tem como você ver, e aí fica mais fácil de você entender. (EXT8)

26 Disponível em: <http://www4.pucsp.br/geogebrala/submissao/artigos.html>. Acesso em mar. 2018. 
Também tem professor, isso acontece muito em matéria de cálculo, ele tá falando de um gráfico, mas só falando, não tá mostrando pra você o gráfico. Pra quem acha que vai fixar melhor vendo o gráfico... Eu consigo imaginar o gráfico, só que eu acho que eu fixo melhor se eu vir. Então, em vez de desenhar, eu boto a expressão no aplicativo, o GeoGebra, e vejo o gráfico. Isso ajuda a visualizar o que o professor tá falando, às vezes ele não gosta de desenhar, só tá falando, e isso ajuda. (EXT9)

Estudantes de cursos diferentes apresentaram visões distintas do GeoGebra em sala de aula. Um deles mencionou experiência com professores que incentivaram o uso; outro, ao contrário, destacou que o app deveria mais explorado pelos docentes, para que os alunos aprendam a utilizar o recurso.

O GeoGebra eu conheci através dos professores mesmo. É uma iniciativa muito bacana, porque alguns professores aqui tentam trazer como você pode levar a matemática de uma forma diferente na sala de aula. Você tendo a oportunidade, como você vai fazer isso? De quais maneiras você vai levar isso pra sala de aula? Então a gente tem alguns professores que têm essa mentalidade de passar pra gente as possibilidades que a gente pode levar diversas formas de conteúdo. (EXT4)

O GeoGebra, que até hoje eu não sei usar, é um construtor de gráficos. O professor, na sala de aula, tinha o dele no laptop, e falou que a gente podia instalar no próprio celular. Só que ele não incentivava o uso do GeoGebra dentro das aulas dele. Dizia 'ah, vocês já sabem fazer isso, já testaram o GeoGebra em casa, né?'. Eu não. Por que não pega uma aula e mostra como se aplica isso no GeoGebra? Se todo mundo tem celular aqui e todo mundo tem como fazer? É um recurso que ele podia adotar na aula dele e a gente ia saber usar aquilo ali. Porque não adianta ter aquilo, é um construtor de gráficos. Mas construir gráfico no quadro é uma coisa, construir no aplicativo é outra. São muitos recursos, e nem todo mundo sabe usar. Então faltou isso, acho que ele podia amarrar mostrando pros alunos. (EXT12)

Embora não fosse um dos objetivos deste estudo analisar a visão dos entrevistados sobre a atuação e a postura dos professores em relação ao uso de dispositivos móveis na educação, o tema surgiu em todas as conversas, a partir de questões do protocolo de entrevista e/ou a partir de reflexões espontâneas, como no relato acima transcrito. Por este motivo, optou-se por examinar com mais detalhes alguns aspectos relacionados às expectativas dos estudantes em relação aos docentes, conteúdo tratado na próxima seção. 


\subsection{6}

\section{Atuação e postura dos professores}

Com base nas entrevistas realizadas nesta dissertação, é possível afirmar que uma parte dos docentes dos cursos frequentados pelos participantes utiliza recursos como redes sociais, e-mails, grupos de mensagens e ambientes de nuvem para se comunicar e compartilhar materiais com os alunos. Estas iniciativas, entretanto, são consideradas incipientes por alguns dos estudantes, que gostariam de ver os dispositivos móveis incorporados em atividades desenvolvidas dentro e fora da sala de aula, como exemplificam os trechos a seguir:

Se tivessem propostas didáticas onde tivesse o uso do aparelho de telefone, seria ótimo. Só que as aulas que eu tenho e visto ultimamente, nenhuma delas te leva a usar o telefone. $\mathrm{Na}$ faculdade isso não tem sido proporcionado, pelo menos no meu curso, não sei em outras áreas. Aqui ninguém nunca propôs uma atividade que a gente tenha que usar o telefone. E eu vejo que todo mundo usa telefone, então por que não usar a favor da gente? A tecnologia hoje tá com todas as informações que você precisa, então vale o professor andar junto com a tecnologia, com certeza a aula dele seria melhor. (EXT7)

Pelo menos aqui eu ainda não aprendi, nenhuma matéria ensinou sobre o uso do celular na educação. Então a gente tem que estudar sobre, não basta levar só o celular pra dentro de sala, pra todos os alunos, porque eles não vão fazer aquilo que a gente quer que faça. De repente nem a gente tá preparado pra isso, e a gente tem que se preparar pra que a gente use o celular. (EXT8)

Tem algumas aulas em que seria interessante se o professor jogasse materiais, jogasse exemplo de exercícios, mostrasse sites, canais de videoaula. Acho que dá pra explorar mais, até pra balancear um pouco isso das pessoas usando muito a rede social e usar mais pra acompanhar os conteúdos. (EXT10)

Além de ter sido pouco mencionado o uso de dispositivos móveis por professores em atividades pedagógicas (apenas três atividades), os estudantes relataram que há docentes que reclamam do uso do celular em sala e outros que proíbem os alunos de acessarem o dispositivo durante a aula. Mais um exemplo do descolamento que há entre as práticas existentes no ambiente escolar/acadêmico e o cotidiano dos jovens.

Para alguns dos entrevistados, o uso dos dispositivos móveis poderia tornar as aulas mais "dinâmicas", "interessantes", "estimulantes", "menos cansativas". 
Um deles resumiu o sentimento frente à única atividade proposta por um professor com o uso do celular da qual participou:

Eu achei ótimo. Ele fez a turma inteira gostar, porque interagiu com o que a gente está acostumado a ter na mão, né? Quando ele falou 'vocês vão fazer uma pesquisa pela Urca', a cara da turma inteira era de desânimo. Aí ele 'não, mas a pesquisa vocês vão fazendo no Google e vão tirando foto do monumento com o celular', aí todo mundo 'ah, facilitou'. (HUM1)

Outro estudante sugeriu que a adoção do celular como recurso pedagógico poderia reduzir a distração em sala de aula. Ele usou como exemplo uma aula que teve num dos laboratórios da universidade, com a utilização do computador.

Foi uma aula que rendeu muito bem. Eu pude ver, não houve distração por parte de nenhum aluno. Era o computador, a baia aqui protegendo e ninguém olhando pro lado, a chance de entrar no Facebook era enorme, e ninguém entrava. E onde você tem pessoas não te estimulando a usar o telefone você vê as pessoas mais usando as redes sociais. (EXT7)

Com relação à atuação do professor, algumas falas expressam ou sugerem que ele deve servir como um guia, orientando práticas de uso do celular no estudo e ajudando a buscar informações e utilizar melhor os recursos disponíveis.

O professor tem que guiar a gente naquele conhecimento que a gente ainda vai receber. Mesmo o conhecimento já tendo no celular, você se atirar naquilo... Eu já experimentei isso, já quis pegar a matéria na frente, e você se jogar naquilo às vezes não traz resultado nenhum. Porque você tem que ter uma base prévia pra poder aprender aquilo, se não [tiver] não vai fazer muito sentido. Você pode até ler a fórmula, fazer um exercício, mas não vai entender como aquilo funciona. $\mathrm{O}$ professor é quem vai te guiar, você tem que aprender isso, tem que aprender aquilo, e você tem que seguir esse caminho pra poder chegar lá. (EXT5)

O papel de uma pessoa educadora, não aquela pessoa que vai controlar a aula. Acho que partiria dele guiar. 'Baixa esse aplicativo aqui que é legal pra vocês fazerem planejamento de projetos'. Ou 'baixa esse aplicativo porque no meu trabalho vou querer que vocês façam isso pelo celular'. (EXT6)

Acho que o celular pode aproximar da seguinte maneira: você tem um conteúdo pra aplicar pra um aluno e você tem que ajudar a construir, não pode deixar ele usar aquela ferramenta sozinho. Tem que mostrar pra ele quais são os passos que ele precisa fazer pra construir determinada coisa. O aluno, utilizando o celular 
como recurso dentro da disciplina, ele consegue enriquecer mais a aula, consegue buscar muita coisa pra complementar a aula. (EXT12)

Ele [o celular] até pode tirar uma dúvida em tempo real ali, talvez o professor não tenha uma resposta e vá buscar na internet através do celular. Mas ele não substitui o conhecimento adquirido por uma pessoa. Pode jogar todo o conhecimento do universo ali, mas se você não tiver pré-requisitos, uma orientação nessa busca dessa informação, não adianta nada. Vão aparecer milhões de informações ali que você não vai conseguir concatenar e não vai conseguir produzir conhecimento. A função do professor é facilitar o conhecimento para o aluno. Facilitar o caminho, facilitar o meio, facilitar as condições para que o aluno tenha um aprendizado e um aprendizado significativo. (HUM2)

Se o professor conseguir, se ele souber utilizar esse meio trazendo pra turma, mostrando a necessidade do diálogo mas também dizendo que você pode utilizar isso pra fazer uma pesquisa, pra formulário, pra algumas situações, ele acaba agilizando o processo. Facilita muito o entendimento do professor com a turma e da turma sobre as funções tecnológicas em si. (HUM3)

Silva (2016) pondera sobre o papel que pode ser desempenhado pelo professor como intermediário da relação entre estudantes e tecnologias:
O professor deve agir como elemento mediador entre a cognição individual dos alunos e o meio, propondo atividades que aperfeiçoem aptidões específicas que levem $o$ aluno a desenvolver estratégias de aprendizagem que culminem em construção de conceitos científicos se aproveitando da inteligência coletiva. (SILVA, 2016, p. 183)

Bannell et al. (2016) observam que, embora crianças e jovens tenham habilidade no uso de recursos dos dispositivos eletrônicos, como lidar com configurações de hardware e programas e, no caso dos celulares, aplicativos, não se observa o mesmo nível de capacidade para buscar, selecionar e analisar informações, bem como produzir e divulgar novos conteúdos. "Essas são habilidades importantes para aquisição/construção de conhecimentos com o uso da internet e, de maneira geral, o seu desenvolvimento exige mediação de pessoas que já as internalizaram.” (BANNELL et al., 2016, p. 70). Na mesma direção, EshetAlkalai (2004) aponta que a capacidade de buscar e recolher fragmentos de informações na web, analisar a confiabilidade delas e integrá-las em um novo conjunto de argumentos, com ideias próprias, é a habilidade digital mais importante 
para o mundo atual, sobretudo no meio acadêmico, porque é uma habilidade cognitiva. Segundo o autor, há uma visão de que os estudantes já têm essa habilidade e, por isso, os professores entendem que não precisam ensinar tais competências.

Outro aspecto deve ser considerado nesta discussão: a pesquisa TIC Educação 2016, realizada com 1.854 professores de escolas de todo o Brasil, mostra que $50 \%$ dos docentes afirmaram que aprendem e se atualizam nas atividades relacionadas no computador ou à internet com seus alunos. Além disso, $70 \%$ deles disseram nunca ter participado de curso de capacitação sobre como usar o computador e a internet em atividades com os estudantes (CETIC.br, 2016). É possível que uma parte dos docentes não se sinta devidamente capacitada para explorar o uso das tecnologias da informação e comunicação em atividades que estimulem a autonomia e a produção autoral por parte dos alunos. Nesse sentido, Silva, Samá e Lunardi (2017) sugerem que, no âmbito do ensino superior, há necessidade de investimento na formação docente, com foco em elementos cognitivos e pedagógicos das tecnologias móveis.

Apesar dessas constatações, há uma carência de estudos que apresentem o ponto de vista dos professores sobre o uso de dispositivos móveis de comunicação e seu papel como mediadores, como apontam Almeida e Araújo Jr. (2013) e Pedro, Barbosa e Santos (2018). Por outro lado, encontram-se na literatura (KOCHHANN; FERREIRA; SOUZA, 2015; KAIESKI et al., 2015; FARLEY et al., 2015; MARTINELL; CASILLAS, 2016, entre outros) trabalhos que apresentam potencialidades educativas das redes sociais, aplicativos e outros recursos acessíveis por dispositivos móveis, com propostas de atividades voltadas ao processo de ensino e aprendizagem no ensino superior. Como defende Mantovani (2016), é preciso pensar a formação docente na perspectiva de uma "ecologia da ubiquidade", por meio de um modelo de comunicação multidirecional e dialógico.

\subsection{7 \\ Facilidade, praticidade e informação}

Ao fim das entrevistas, solicitou-se que os estudantes associassem três palavras ou expressões curtas ao tema em questão - uso do celular em atividades 
de estudo. Embora a reflexão sobre o resultado seja feita a partir da visão coletiva dos participantes da pesquisa, não foi intenção provocar uma discussão sobre teorias das representações sociais ${ }^{27}$, mas sim relacionar os termos que se destacaram com os dados produzidos a partir das entrevistas.

Para facilitar a visualização dos termos mencionados, optou-se por criar uma nuvem de palavras $^{28}$, que representa graficamente a frequência das palavras presentes em um texto.

Imagem 5 - Nuvem de palavras

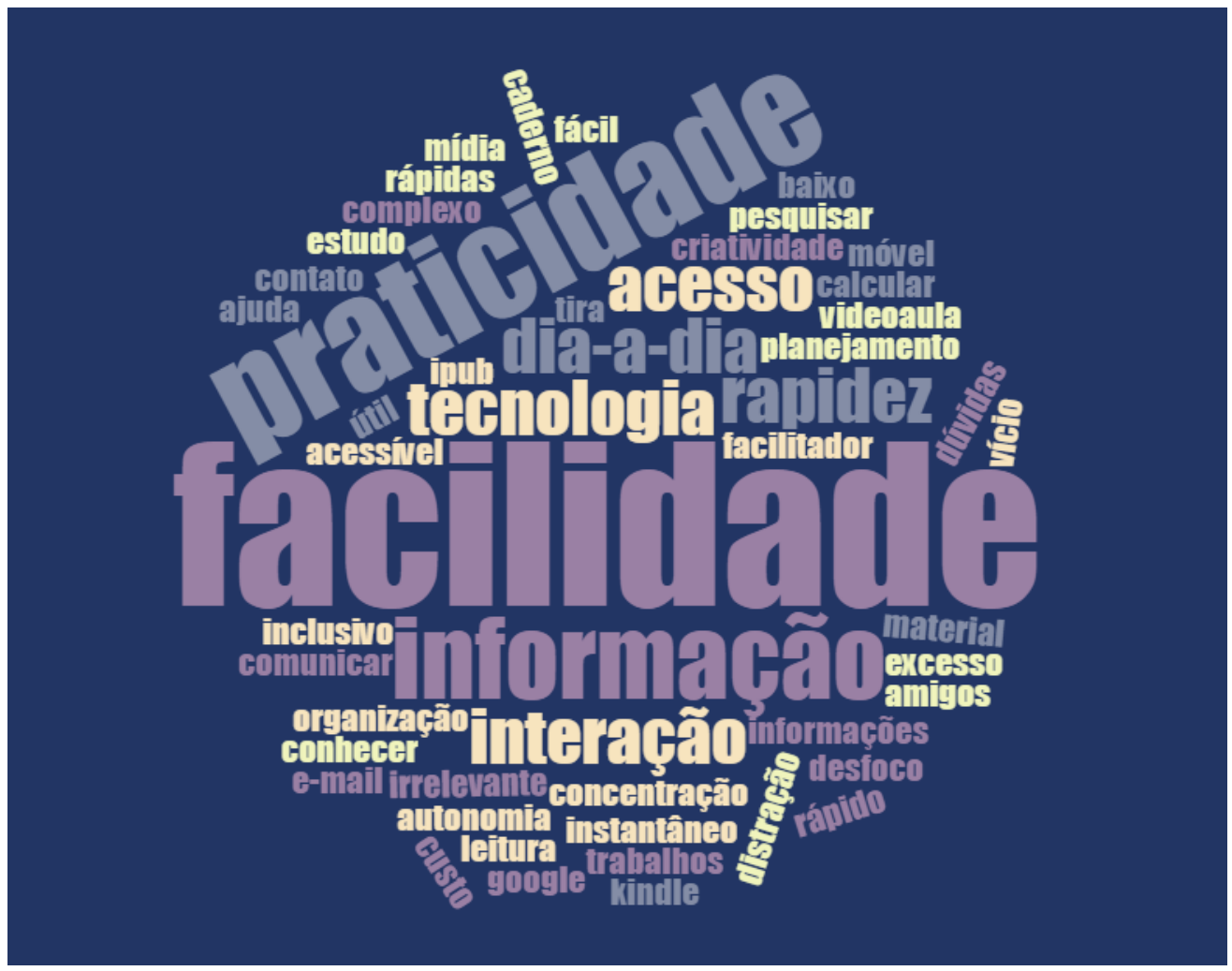

Fonte: Elaborada pela autora com dados da pesquisa.

As três palavras que mais se destacaram, em ordem decrescente de frequência, foram: facilidade, praticidade e informação. Na sequência, vieram acesso, tecnologia e interação, seguidas pelos demais registros. Em nuvens criadas especificamente para os dois grupos de entrevistados (Exatas e Humanas), não

27 Crusóe (2004) apresenta algumas considerações sobre teorias das representações sociais e sua relação com a educação.

28 Criada com a ferramenta WordClouds.com, disponível em <https://www.wordclouds.com/〉. Acesso em 18 fev. 2018. 
houve diferença nas palavras mais citadas. Entre os estudantes de Humanas, porém, informação vem antes de praticidade, e no grupo de Exatas a palavra informação aparece na mesma frequência que tecnologia.

A maior recorrência da palavra facilidade e suas variações (fácil e facilitador) pode estar relacionada à naturalidade com que os estudantes percebem o uso e a presença dos dispositivos digitais em seu cotidiano. $\mathrm{O}$ trecho a seguir indica esse pensamento:

Eu já meio que nasci inserido nesse meio tecnológico, então particularmente desde que tive celular ou computador sempre vivia estudando de certa forma, então pra mim é uma coisa super natural. (HUM7)

Jacks e Schmitz (2018, p. 127) recorrem a Martín-Barbero para destacar a empatia dos jovens com a cultura tecnológica, caracterizada pela facilidade no manejo das redes informáticas, de tal forma "que a habilidade, destreza, expressividade e sensibilidade diante das novas experiências culturais nos usos dos meios estão imbricadas na própria configuração desse sujeito juvenil”.

Ao mesmo tempo, alguns estudantes descreveram dificuldades para utilizar o celular em atividades de estudo, relacionadas a questões mais técnicas (recursos limitados para formatação de textos, tamanho reduzido da tela etc.) e também ao conteúdo (problemas no entendimento), o que pode indicar que as menções à facilidade têm uma conotação mais geral, voltada apenas para as habilidades mais gerais de uso dos dispositivos - como manejar o aparelho, acessar os recursos por meio da tela touchscreen, trocar mensagens, navegar na internet e baixar aplicativos, entre outras. Para os entrevistados, tais ações são realizadas com facilidade, uma vez que fazem parte de seu dia a dia. Como ressaltado anteriormente, tais competências não bastam para a mobilização efetiva de processos de aprendizagem.

A segunda palavra mais citada, praticidade, aponta para uma relação com a questão da mobilidade e da presença constante do celular; o fato de estar com o dispositivo em qualquer lugar e poder acessá-lo a qualquer momento, até mesmo em movimento. Pode ser relacionada também com a característica de ser um dispositivo portátil e leve, que pode armazenar arquivos de textos, livros, imagens etc. e ser facilmente manipulado e transportado. Muitos estudantes salientaram a questão da praticidade aliada a estes dois aspectos. 
A terceira palavra mais registrada foi informação, em conformidade com o que mostraram as entrevistas, uma vez que o acesso à informação foi um dos usos mais apontados pelos estudantes e um dos principais pontos destacados como vantagens e motivações para utilizar o celular em atividades de estudo.

A partir do que contaram os participantes da pesquisa, e à luz sobretudo das teorias que tratam da interação social, algumas questões relacionadas à aprendizagem entre pares serão comentadas no capítulo a seguir. 


\section{Aprendizagem entre pares: uma breve reflexão}

No livro Cultura da Convergência, Henry Jenkins discorre sobre as possibilidades de troca de conhecimento entre os indivíduos: "Nenhum de nós pode saber tudo; cada um de nós sabe alguma coisa; e podemos juntar as peças, se associarmos nossos recursos e unirmos nossas habilidades." (JENKINS, 2009, p. 28). Nas últimas duas décadas, principalmente, as tecnologias digitais de informação e comunicação, em conjunto com a internet, propiciaram novas formas de relacionamento e de compartilhamento de informações, que independem do espaço e do tempo e favorecem a interação, propiciada também pela lógica de redes (CASTELLS, 2002) característica da sociedade pós-industrial. Neste contexto, observam-se mudanças nos fluxos de circulação do saber, o qual não se mantém apenas na relação professor-aluno, mas também entre os alunos, num ambiente colaborativo mediado pela tecnologia, em que o estudante se sente capaz de buscar informação em lugares dispersos e fora do espaço escolar. Tratam-se dos saberesmosaico que circulam na sociedade e configuram uma das profundas transformações do mundo atual (MARTÍN-BARBERO, 2014).

Laird e Kuh (2005) observam uma relação positiva entre o uso de tecnologia com fins educacionais e o envolvimento com atividades de aprendizagem ativa e colaborativa e de interação entre alunos e professores. Ao analisar dados da Pesquisa Nacional de Engajamento Estudantil (NSSE, na sigla em inglês), os autores apontaram uma correlação entre a frequência de comunicação on-line com colegas e uma maior identificação da aplicação de teorias ou conceitos a problemas práticos ou em novas situações em seus cursos. Os estudantes que mais se comunicavam on-line também relataram interações mais frequentes com o corpo docente.

O’Nuallain e Brennan (2004, apud MOURA, 2010) indicam algumas vantagens associadas à aprendizagem colaborativa mediada por dispositivos móveis de comunicação: aumento da compreensão dos conteúdos curriculares; aumento da motivação pela discussão e pelo diálogo; retorno rápido e efetivo; acesso a visões e perspectivas alternativas.

Os relatos dos estudantes que participaram desta pesquisa ressaltam o papel dos dispositivos móveis de comunicação como mediadores das relações mantidas 
com seus pares. Para alguns entrevistados, esta interação tem influência na aprendizagem, como preconizam as teorias da psicologia sócio-histórica. Os estudantes também relatam práticas de estudo em conjunto, com o uso dos celulares, que remetem ao modelo de cognição distribuída, em que o processo cognitivo é distribuído por meio de ações múltiplas e integradas (REGIS; MESSIAS, 2012), indissociáveis da interação/ação com o mundo (SILVA, 2016).

Um dos aspectos que mais se destacou nas entrevistas é o fato de que, para os estudantes, os dispositivos móveis favorecem a colaboração e o compartilhamento de informações, ideias e conhecimentos, de formas mais ou menos ativas e producentes. Ter um celular à mão (desde que esteja com a bateria carregada e, dependendo da necessidade, com acesso à internet) significa poder, a qualquer momento e em qualquer lugar, acessar um conteúdo compartilhado em ambientes de rede, acionar um ou mais colegas para esclarecer uma dúvida ou consultar membros da turma sobre determinado assunto de interesse coletivo. O que se observa a partir das falas é que tais ações não são apenas possibilidades, mas acontecem com frequência e já estão inseridas nas práticas cotidianas dos estudantes.

Algumas das práticas relatadas pelos entrevistados evidenciam características de aprendizagem colaborativa, na qual a aprendizagem resulta como efeito da interação entre pares que trabalham em conjunto para resolver um problema ou realizar uma tarefa (TORRES; IRALA, 2015). Damiani (2008, p. 223) sugere que as interações entre pares podem gerar questionamentos sobre saberes já adquiridos e possibilitar contato com novos raciocínios e comportamentos, "enriquecendo o repertório de pensamento e a ação dos estudantes". A fala de um dos entrevistados acerca da resolução de exercícios em conjunto vai ao encontro desta reflexão:

Quem sabia de algumas questões foi postando. 'Ah, essa eu fiz' 'Alguém sabe a 2?' 'Ó, a 3 eu fiz desse jeito' 'Ah, mas eu achei essa resposta'. Aí o outro olhava 'Você errou aqui' Aí o outro 'Ih, é mesmo'. No semestre passado, com Cálculo 2, foi essencial. Eu tenho um pouco de dificuldade na matemática, e aî estava com um amigo resolvendo as questões da lista. Eu só estava olhando, tentando fazer. Aí vi lá uma questão e falei 'Acho que nessa você se equivocou um pouco'. Mas o garoto era muito esperto, muito inteligente, eu achava que eu é que estava errado. Aí ele respondeu 'Você está certo, eu errei mesmo, posta lá o jeito que você fez'. Ele mesmo falou 'É bom a gente ter um grupo 
das pessoas que olham e falam o que está errado assim'. Porque a gente precisava das respostas, o professor deu a lista e a gente precisava saber. Às vezes o meu jeito de fazer é diferente do de outra pessoa, às vezes o outro encontrou uma maneira mais fácil de fazer. (EXT4)

De acordo com o relato, o estudante inicia sua participação apenas observando as conversas do grupo, mas resolve interferir, ao perceber um equívoco na resolução de um dos problemas, e aponta uma solução diferente. A interação, neste caso, permite que o estudante não apenas se beneficie da troca com os demais, mas também compartilhe conhecimento, que poderá ser utilizado por outros estudantes, o que caracteriza a aprendizagem colaborativa.

[...] pode-se considerar que a utilização de recursos como trabalhos em grupo, o uso de tecnologias comunicativas como bate-papos, fóruns de discussão e outras formas de comunicação em grupos, pode levar ao debate de diferentes ideias e ao desencadeamento de novos conflitos cognitivos. A influência de outros indivíduos, atuando como promotores do crescimento cognitivo de si mesmos e de outrem constituem a espinha dorsal da aprendizagem colaborativa. (TORRES; IRALA, 2015, p. 74)

Os entrevistados, de modo geral, consideram como fatores de maior influência para sua aprendizagem a conjugação da comunicação instantânea (com seus colegas e monitores) e do acesso rápido a conteúdos via dispositivos móveis. Os recursos disponíveis no celular possibilitam, por exemplo, dirimir uma dúvida no momento do estudo, por meio da consulta a seus pares ou a um conteúdo disponível na internet, como uma videoaula. Dessa forma, o dispositivo emerge como um meio que favorece a interação e é daí, da relação social, da troca com o mundo, que vem o ganho na aprendizagem.

Aí se eu tenho uma dúvida eu coloco essa dúvida. Se alguém entendeu, vai lá, marca o meu comentário e responde embaixo 'ó, o professor explicou assim, assim, assim. Mas assim é mais simples'. Aí dá alguma analogia, ah, tá entendi. Ou então todo mundo tá estudando pra prova, 'ah, alguém entendeu o tópico tal do texto?', 'ah, tenho aqui um outro texto que ajuda'. Vira uma rede acadêmica ali mesmo, que facilita a gente a uns ajudarem os outros. (HUM1)

A utilização de dispositivos móveis em atividades conjuntas de estudo também requer o desenvolvimento de habilidades de comunicação e de 
relacionamento, como ressaltam Vásquez-Cano e Sevillano (2015). Nos ambientes online, a sociabilidade se constitui a partir de comunidades baseadas em interesses individuais e em valores compartilhados, conectados via internet, o que permite a criação de redes de afinidades (CASTELLS, 2000).

É o que muitas vezes acontece, de acordo com os estudantes, nos grupos de WhatsApp: inicialmente são mais amplos, com a participação de todos ou a maioria de alunos da turma original, e, ao longo do tempo, modificam-se de acordo com a conveniência e a necessidade dos estudantes. O grupo maior, em que há troca intensa de mensagens sobre assuntos diversos, passa a não ser tão interessante àqueles que buscam, por exemplo, tirar dúvidas sobre uma disciplina ou um assunto específico. Cria-se então um grupo com poucos participantes, com mais afinidades entre si:
A gente tem um grupo, não da turma, mas seria um grupo menor, em que se a gente tiver algum tipo de dúvida em alguma coisa a gente coloca ali e discute com os outros, ou compartilha alguma coisa. (EXT1)

Conforme alguns entrevistados, nesses nichos de indivíduos afins é que se dão mais facilmente as trocas. O esclarecimento de dúvidas e a realização conjunta de exercícios via WhatsApp, por exemplo, acontecem em grupos menores ou em conversas com apenas um colega ou monitor.

\section{[...] tem grupos de colegas. A gente brinca, zoa, mas tem horas que a gente se ajuda mesmo. 'Ah, tô precisando desse material', 'como faz isso mesmo?', 'vocês tiveram aula com esse, como é?' [...] A gente sempre tem uns grupos assim bons. Um ajuda o outro. (EXT11)}

A influência e a importância dos pares na aprendizagem foram ressaltadas pelas teorias sócio-históricas, como apontado no Capítulo 2. Nessa direção, os relatos de alguns participantes da pesquisa - por exemplo, quando há o reconhecimento de que com a ajuda de colegas conseguiram compreender e avançar num tópico de estudo - apontam para um diálogo com a perspectiva da interação social como fator que favorece a aprendizagem. 


\section{Considerações finais}

Seja na sala de aula, no pátio da universidade, na rua, no transporte público, num momento de ócio, de lazer ou de emoção: lá estarão pessoas com seus celulares a postos para registrar o momento, compartilhar uma informação ou um sentimento, buscar uma localização correta, ouvir música, trocar mensagens, ler, jogar... A forte presença dos dispositivos móveis de comunicação no cotidiano é uma realidade em diferentes lugares do Brasil e do mundo, ainda que com níveis de acesso e de habilidades de uso distintos. Ao longo desta pesquisa, tal presença se materializou em alguns momentos. No processo do trabalho de campo, meu celular pessoal serviu para fazer contato com os estudantes, gravar em áudio as entrevistas e fazer alguns registros de imagens e vídeo. Em alguns casos, durante as conversas individuais, os entrevistados mantiveram seus aparelhos nas mãos ou à vista em local próximo, embora nenhum deles tenha se distraído com o dispositivo no tempo em que conversamos.

Constatada a utilização massiva dos dispositivos móveis e a conectividade constante, principalmente entre os jovens, e com base nos dados produzidos nesta pesquisa, pode-se dizer que tais dispositivos - especialmente o celular - são elementos mediadores da interação social entre os estudantes. As interações acontecem principalmente em aplicativos de mensagens instantâneas, nas redes sociais, em ambientes de nuvem e no correio eletrônico. O WhatsApp é utilizado por todos os entrevistados em situações cotidianas e pelo menos em uma atividade relacionada ao estudo. Os principais usos do aplicativo relacionam-se à troca de informações sobre a rotina acadêmica; ao compartilhamento de materiais (textos, links, fotos do quadro); à organização e discussão sobre trabalhos em grupo; à resolução de exercícios (entre os estudantes das Exatas); e a conversas para esclarecer dúvidas sobre algum conteúdo. Para os entrevistados, o celular é um recurso fundamental na rotina acadêmica, sobretudo para a comunicação rápida de informações relacionadas ao dia a dia na universidade. Por exemplo, para saber se uma aula foi cancelada, se o professor vai atrasar, que assuntos foram abordados naquele dia, quais textos devem ser lidos para o próximo encontro, quais as datas de provas e de entrega de trabalhos. 
As percepções de ganhos manifestadas nas entrevistas estão ligadas principalmente à viabilidade de acesso à informação e a materiais a qualquer hora e em qualquer lugar pelo celular, o que na visão dos estudantes favorece a aprendizagem. Os entrevistados relacionam ganhos também com a possibilidade de estudar em grupo e consultar colegas, monitores e professores para resolver dúvidas, facilitando e agilizando a compreensão dos conteúdos - o que caracteriza um ambiente de aprendizagem entre pares mediado pelos dispositivos móveis de comunicação.

Já os prejuízos, de forma geral, apontam para a dependência do celular e para seu potencial de distração. Os estudantes reconhecem circunstâncias em que utilizam o dispositivo de forma indevida, na sala de aula ou fora dela, no momento de estudo. Identificam-se situações distintas no que se refere à atenção. Uma delas é quando o estudante é atraído por algum recurso do celular que o distrai do estudo, não resiste e deixa de lado a atividade original, o que aponta para uma perda do controle autônomo do uso do dispositivo. Em outros casos, o estudante recorre deliberadamente ao dispositivo para fugir de alguma situação desinteressante, entediante ou incômoda, principalmente em sala de aula. A opção pelo uso do celular em detrimento às atividades de estudo acontece também quando o estudante se sente afetado por questões emocionais e não se sente em condição de dedicar atenção àquela atividade. Foram observadas algumas estratégias de manejo da atenção, em circunstâncias em que o estudante sente necessidade de manter o foco no estudo - tais como ignorar as notificações de aplicativos, ainda que interrompam a atividade que está sendo realizada.

A comparação entre usos e percepções dos graduandos da área de Exatas e da área de Humanas apontou poucas diferenças: os estudantes de Exatas relataram utilizar o celular para resolução de exercícios em conjunto, o que não foi apontado pelo outro grupo. Os de Exatas também usam mais aplicativos específicos da área, com destaque para o software de construção de gráficos GeoGebra.

Alguns aspectos observados a partir das entrevistas fogem aos objetivos propostos para esta investigação, mas cabe aqui assinalá-los brevemente. Um deles é que foram poucos os relatos de uso do celular para produção de conteúdo criativo - dois estudantes mencionaram atividades com esse perfil, relacionado ao desenvolvimento de processos mentais como imaginação e criatividade e também à participação mais ativa do jovem como produtor de conteúdo, e não apenas 
consumidor. Além disso, apesar de o acesso à informação ter sido apontado como uma das principais vantagens do uso do celular em atividades de estudo, não foram observadas reflexões críticas sobre o conteúdo disponível na internet. É importante ressaltar que o tema não foi provocado durante as entrevistas, mas sua ausência nas falas pode indicar que talvez essa não seja uma questão relevante para os estudantes. Frente à ampla gama de possibilidades que a internet oferece, a literacidade crítica deve ser enfatizada no que se refere à busca, seleção e avaliação das informações (LIVINGSTONE, 2001). Em tempos de discussões sobre pós-verdade, fake news, privacidade e uso consciente das mídias sociais, essa é uma discussão que merece atenção e que pode ser abordada em novos estudos.

Também não foi intenção desta investigação avaliar as habilidades dos jovens com a tecnologia e os dispositivos móveis de comunicação, e sim apontar os principais usos relacionados ao estudo e as percepções sobre estas atividades. Apesar disso, é possível observar que os relatos, em sua maioria, indicam modos de uso similares aos encontrados em pesquisas que consideram a população em geral, à exceção do uso de aplicativos específicos da área de Exatas. Como observado anteriormente, habilidades de seleção e análise das informações e de produção e ressignificação de conteúdos são importantes e devem ser estimuladas em âmbito escolar, sob mediação dos professores.

Foram poucos os relatos de incentivo ao uso dos dispositivos móveis de comunicação como recurso pedagógico, lacuna expressada criticamente por alguns estudantes. Eles mencionaram também episódios de reclamações, por parte dos docentes, e proibições do uso do celular em sala de aula. Na visão dos entrevistados, o dispositivo poderia ser adotado como recurso para atrair o interesse nas aulas. Nesse caso, os professores poderiam atuar como mediadores, dialogando e fornecendo subsídios para o uso crítico e responsável das potencialidades disponíveis na internet.

A possibilidade de se comunicar rapidamente em rede, via dispositivos móveis, e a disponibilidade dos jovens para compartilhar e cooperar entre si podem servir como estímulos à proposição de tarefas que incentivem a colaboração, a mobilização e o engajamento dos estudantes. Bonilla e Pretto (2015) delinearam alguns princípios para o sistema educacional no que se refere às tecnologias digitais e suas possibilidades de movimentos colaborativos, entre eles: acesso aberto a todo e qualquer material educacional; incentivo à leitura crítica e atenta de todas as 
fontes, quer sejam professores, livros ou qualquer outra; e centramento do processo de ensino-aprendizagem na criação e produção de culturas e conhecimentos, em oposição ao simples consumo de informação.

Embora seja importante ressaltar as limitações da pesquisa - desenvolvida em apenas uma instituição de ensino superior, com número restrito de participantes, o que não permite generalizações acerca dos resultados - , os dados produzidos podem servir como subsídios para pensar as relações de jovens universitários com seus dispositivos móveis de comunicação. O questionamento recorrente dos estudantes (“Se a gente usa o tempo todo, por que não usar na sala de aula?”) deve ser levado em consideração, ainda que haja mais perguntas do que respostas acerca de como desenvolver atividades e estimular o uso efetivo desses dispositivos, e sobre os ganhos que essa dinâmica pode propiciar aos processos de estudo e aprendizagem. 


\section{7 \\ Referências bibliográficas}

ABREU, C. N. et al. Dependência de Internet e de jogos eletrônicos: uma revisão. Revista Brasileira de Psiquiatria. São Paulo, 2008, vol. 30, n. 2, p. 156-167. Disponível em: <http://www.scielo.br/scielo.php?script=sci_arttext\&pid=S151644462008000200014\&lng=en\&nrm=iso\&tlng=pt $>$. Acesso em abr. 2018.

AGÊNCIA NACIONAL DE TELECOMUNICAÇÕES. Brasil registra 241 milhões de linhas móveis em operação em setembro de 2017. Portal da Anatel. Brasília, DF, nov. 2017. Disponível em: <http://www.anatel.gov.br/institucional/ noticias-destaque/1805-brasil-registra-241-milhoes-de-linhas-movel-emoperacao-em-setembro-de-2017>. Acesso em dez. 2017.

ALCALÁ, Z. Z. Uso de las TIC de los estudiantes universitarios: ventajas y desventajas. In: GONZÁLEZ, R. L.; HERNÁNDEZ, D. H.; SANTOS, A. J. B. Las tecnologías digitales en los contextos educativos - La voz de los estudiantes. Colección Háblame de TIC 4. Córdoba: Editorial Brujas, $1^{\text {a }}$ ed., 2017, p. 61-80.

AL-EMRAN, M.; ELSHERIF, H. M.; SHAALAN, K. Investigating attitudes towards the use of mobile learning in higher education. Computers in Human Behavior. Volume 56, mar./2016, p. 93-102. Disponível em: <https://www.sciencedirect.com/science/article/pii/S074756321530248X>.

Acesso em nov. 2016.

ALEVIZOU, G. Da mediação à datificação: teorizando tendências em evolução nas mídias, tecnologia e aprendizagem. In: FERREIRA, G. M. S.; ROSADO, L. A. S.; CARVALHO, J. S. Educação e Tecnologia: Abordagens críticas. Rio de Janeiro: Universidade Estácio de Sá, 2017, 663p. Disponível em <https://ticpe.files.wordpress.com/2017/04/ebook-ticpe-2017.pdf〉. Acesso em abr. 2018.

ALMEIDA, R. R.; ARAÚJO JR., C. A. F. de. O uso de dispositivos móveis no contexto educativo: Análise de teses e dissertações nacionais. Revista Tempos e Espaços em Educação. Aracaju: UFS, vol. 6, n. 11, jul-dez./2013. Disponível em: <https://seer.ufs.br/index.php/revtee/article/view/2538>. Acesso em abr. 2018.

ALQUETE, T. et al. Aprendizagem mediada por artefatos digitais móveis. In: 5o Simpósio Hipertexto e Tecnologias na Educação. Anais Eletrônicos do Simpósio Hipertexto e Tecnologias na Educação. Recife: NEHTE/UFPE, 2013. Disponível em: $\quad<$ http://nehte.com.br/simposio/anais/Anais-Hipertexto2013/Aprendizagem $\% 20$ mediada\%20por\%20artefatos\%20digitais $\% 20 \mathrm{~m} \% \mathrm{C} 3 \% \mathrm{~B}$ 3 veis.pdf $>$. Acesso em nov. 2016. 
ALSADOON, H. S. Use of cell phones in education at King Saud University in the Kingdom of Saudi Arabia. Tese de Doutorado. Department of Educational Studies, The Patton College of Education, Ohio University, dez./2012, 167p.

AMIGO, B.; OSORIO, F.; BRAVO, M. C. Mobile communication technologies and ontological security. Convergencia - Revista de Ciencias Sociales. Universidad Autónoma del estado de México, no 74, mai-ago. 2017, p. 39-61.

BANNELL, R. Uma faca de dois gumes. In: FERREIRA, G. M. S.; ROSADO, L. A. S.; CARVALHO, J. S. Educação e Tecnologia: Abordagens críticas. Rio de Janeiro: Universidade Estácio de Sá, 2017, 663p. Disponível em: <https://ticpe.files.wordpress.com/2017/04/ebook-ticpe-2017.pdf〉. Acesso em abr. 2018.

BANNELL, R. et al. Educação no século XXI - Cognição, tecnologias e aprendizagens. Petrópolis, RJ: Vozes; Rio de Janeiro: Editora PUC, 2016. 158p.

BARDIN, L. Análise de Conteúdo. São Paulo: Edições 70, 2009, 281p.

BAUER, M. W. Análise de conteúdo clássica: Uma revisão. In: BAUER, M. W.; GASKELL, G. Pesquisa qualitativa com texto, imagem e som: Um manual prático. Petrópolis, RJ: Editora Vozes, 2013, 516p.

BAUMAN, Z. Modernidade Líquida. Rio de Janeiro: Jorge Zahar Ed., 2001. 258p.

BONILLA, M. H.; PRETTO, N. D. L. Movimentos colaborativos, tecnologias digitais e educação. Em Aberto. Brasília: v. 28, n. 94, p. 23-40, jul./dez. 2015.

BOUHNIK, D.; DESHEN, M. WhatsApp goes to school: Mobile instant messaging between teachers and students. Journal of Information Technology Education: Research, vol. 13, 2014, p. 217-231. Disponível em: <http://www.jite.org/documents/Vol13/JITEv13ResearchP217-

231Bouhnik0601.pdf>. Acesso em mar. 2018.

BOTTENTUIT JUNIOR, J. B.; ALBUQUERQUE, O. C. P.; COUTINHO, C. P. WhatsApp e suas aplicações na Educação: Uma revisão sistemática da literatura. Revista EducaOnline. Rio de Janeiro: Latec/UFRJ, vol. 10, n. 2, mai-ago/2016. Disponível em: <http://www.latec.ufrj.br/revistas/index.php?journal=educaonline \&page $=$ article \&op $=v i e w \& p a t h \% 5 B \% 5 \mathrm{D}=824 \&$ path $\% 5 \mathrm{~B} \% 5 \mathrm{D}=746>$. Acesso em dez. 2017.

BRASIL. Fundação Instituto Brasileiro de Geografia e Estatística. Resolução no 4 , de 28 de agosto de 2017. Divulga as estimativas da População para Estados e Municípios, com data de referência em $1^{\circ}$ de julho de 2017. Diário Oficial da União. Brasília, DF, 30 ago. 2017, p. 58. Disponível em: $<\mathrm{http}$ ://pesquisa.in.gov.br/imprensa/jsp/visualiza/index.jsp?jornal=1\&pagina=58\& data=30/08/2017> . Acesso em dez. 2017. 
BRCKALORENZ, A. et al. Student perspectives on the importance and use of technology in learning. Paper - Annual Forum of the Association for Institutional Research. California, mai, 2013.

BRIZ-PONCE, L.; JUANES-MÉNDEZ, J. A. Mobile devices and apps, characteristics and current potential on learning. Journal of Information Technology Research. 2015, v.8, iss 4, p.26-37.

BROOKS, D. C. ECAR Study of Faculty and Information Technology - 2015. Relatório de pesquisa. Louisville, CO: ECAR, 2015. Disponível em: $<$ https://library.educause.edu/ /media/files/library/2015/8/ers1510r.pdf >. Acesso em set. 2016.

BUDINSKI, N. An example how GeoGebra can be used as a tool for STEM. The International Journal for Technology in Mathematics Education, vol. 24, ed. 3, jul-set./2017, p. 149-153. Disponível em: <https://search.proquest.com/ docview/1971626829/A5EE2903C8594664PQ/4?accountid=26635>. Acesso em mar. 2018.

CALDAS-COULTHARD, C. R. Caro colega: Exclusão linguística e invisibilidade. Discurso \& Sociedad, vol. 1, n. 2, 2007, p. 230-246. Disponível em: $<$ http://www.dissoc.org/ediciones/v01n02/DS1(2)Caldas-Coulthard.pdf >. Acesso em abr. 2018.

CASTELLS, M. A Sociedade em Rede. A Era da informação: economia, sociedade e cultura, vol. 1. $6^{\text {a }}$ ed. São Paulo: Editora Paz e Terra, 2002.

Internet y la Sociedad en Red. In: Lliçó inaugural del programa de doctorat sobre la societat de la informació i el coneixement. Barcelona: Universidad Oberta de Catalunya, 2000. Disponível em: <http://www.uoc.edu/web/cat/articles/castells/print.html>. Acesso em out. 2017.

CASTELLS, M.; FERNÁNDEZ-ARDÈVOL, M.; GALPERIN, H. Síntesis de resultados y conclusiones. In: CASTELLS, M.; FERNÁNDEZ-ARDÈVOL, M.; GALPERIN, H. Comunicación móvil y desarrollo econômico y social em América Latina. Madri: Fundación Telefónica, 2011, p. 319-348.

CARVALHO, V. M. M. G. Expectativas dos estudantes adultos do ensino superior a distância sobre a utilização de dispositivos móveis para a aprendizagem. Dissertação (Mestrado em Comunicação Educacional Multimédia) - Universidade Aberta de Portugal. Lisboa, 2012, 153p.

CETIC.br. Pesquisa sobre o uso das Tecnologias da Informação e Comunicação nos domicílios brasileiros: TIC Domicílios 2016. São Paulo: Comitê Gestor da Internet no Brasil, 2017. Disponível em: <http://cetic.br/publicacao/pesquisasobre-o-uso-das-tecnologias-de-informacao-e-comunicacao-nos-domiciliosbrasileiros-tic-domicilios-2016/>. Acesso em jan. 2018. 
Pesquisa sobre o uso das Tecnologias da Informação e Comunicação nas escolas brasileiras: TIC Educação 2016. São Paulo: Comitê Gestor da Internet no Brasil, 2017. Disponível em: <http://cetic.br/publicacao/ pesquisasobre-o-uso-das-tecnologias-de-informacao-e-comunicacao-nas-escolasbrasileiras-tic-educacao-2016/>. Acesso em jan. 2018.

CHAIB, J. 'A escola atual está fadada ao fracasso', diz educador José Pacheco. Correio Braziliense [ed. on-line]. Brasília, 20 de novembro de 2016, Brasil/Política. Disponível em: <http://www.correiobraziliense.com.br/app/noticia/ brasil/2016/11/20/internas_polbraeco,557877/a-escola-atual-esta-fadada-aofracasso-diz-educador-jose-pacheco.shtml>. Acesso em 02 dez. 2016.

CHANG, A. Y. et al. Use of mobile learning by resident physicians in Botswana. Telemedicine Journal and e-Health. 2012, v. 18(1), p. 11-13. Disponível em: <https://www.ncbi.nlm.nih.gov/pubmed/22171597>. Acesso em nov. 2016.

CHARLOT, B. Da relação com o saber às práticas educativas. São Paulo: Editora Cortez, 2013.

CHARTIER, R. A aventura do livro. Do leitor ao navegador. Conversações com Jean Lebrun. $1^{a}$ reimpressão. Tradução: Reginaldo Carmello Corrêa de Moraes. São Paulo: Imprensa Oficial do Estado de São Paulo/Editora UNESP, 1998, 155p.

CRUSOÉ, N. M. de C. A teoria das representações sociais em Moscovici e sua importância para a pesquisa em educação. Aprender - Caderno de Filosofia e Psicologia da Educação. Vitória da Conquista: Uesc, ano II, n. 2, 2004, p. 105114.

DAMIANI, M. F. Entendendo o trabalho colaborativo em educação e revelando seus benefícios. Revista Educar. Curitiba: Editora UFPR, n. 31, 2008, p. 213-230.

DOURADO, C. D. B. F. A percepção de jovens universitários sobre o uso do celular: Potencialidades e fragilidades para a aprendizagem em sala de aula. Dissertação (Mestrado em Educação) - Universidade Católica de Brasília. Brasília, 2015, 113p.

DUARTE, R. Entrevistas em pesquisas qualitativas. Revista Educar. Curitiba: Editora UFPR, n. 24, 2004, p. 213-225. Disponível em: <http://www.scielo.br/ pdf/er/n24/n24a11.pdf>. Acesso em out. 2016.

DUKIC, Z.; CHIU, D.; LO, P. How useful are smartphones for learning? Perceptions and practices of Library and Information Science students from Hong Kong and Japan. Library Hi Tech. 2015, vol. 33, iss. 4, p. 545-561.

ESHET-ALKALAI, Y. Digital literacy: A conceptual framework for survival skills in the digital era. Journal of Educational Multimedia and Hypermedia, vol. 13, n. 1, 2004, p. 93-106. 
FARLEY, H. et al. How do students use their mobile devices to support learning? A case study from an Australian Regional University. Journal of Interactive Media in Education. 2015 (1), n. 14, p. 1-13. Disponível em: <https://jime.open.ac.uk/article/10.5334/jime.ar/>. Acesso em nov. 2016.

FERREIRA, D. F. M. A. Aprendizagem móvel no ensino superior o uso do smartphone por alunos do curso de pedagogia. Dissertação (Mestrado em Educação Matemática e Tecnológica) - Universidade Federal de Pernambuco. Recife, 2015, 107p.

FERREIRA, H. M. C. Dinâmicas de uma juventude conectada: a mediação dos dispositivos móveis nos processos de aprender-ensinar. Tese de doutorado. Universidade Federal do Rio de Janeiro. Rio de Janeiro, 2014, 272 p.

FOTI, M.; MENDEZ, J. Mobile Learning: How students use mobile devices to support learning. Journal of Literacy and Technology. Vol. 15, n. 3, dez./2014, p. 58-78. Disponível em: <http://www.literacyandtechnology.org/uploads/ 1/3/6/8/136889/jlt_v15_foti.pdf>. Acesso em nov. 2016.

FRANCO, M. L. P. B. Análise de Conteúdo. $4^{\mathrm{a}}$ edição, Série Pesquisa, vol. 6. Brasília: Liber Livro, 2012, 87p.

FUNDAÇÃO TELEFÓNICA. Juventude conectada 2. São Paulo: Fundação Telefônica Vivo, 2016. 247p.

GIDDENS, A. Confiança e Modernidade. In: GIDDENS, A. As consequências da modernidade. Tradução: Raul Fiker. São Paulo: Editora Unesp, 1991, 187p.

GIKAS, J.; GRANT, M. M. Mobile computing devices in higher education: Student perspectives on learning with cellphones, smartphones and social media. Internet and Higher Education. 2013, v. 19, p. 18-26. Disponível em: <http://www.sciencedirect.com/science/journal/10967516/19>. Acesso em nov. 2016.

GONZÁLEZ, R. L. Internet: recurso esencial en la vida de los estudiantes universitarios. In: MARTINELL, Alberto R.; CASILLAS, Miguel A. (coords.). Internet en Educación Superior. Colección Háblame de TIC 2. Córdoba: Editorial Brujas, 2015, 205p.

GREENFIELD, D. As propriedades de dependência do uso de internet. In: YOUNG, Kimberly S.; ABREU, Cristiano N. Dependência de Internet Manual e Guia de Avaliação e Tratamento. Editora Artmed, 2011, 344p. 
GUERRA, A. M. M. Reseña de Márquez, María (2013): Género gramatical y discurso sexista. PragmaLinguistica, n. 22, 2014, p. 174-180. Disponível em: $<$ https://revistas.uca.es/index.php/pragma/article/view/2051>. Acesso em abr. 2018.

HUTCHINS, E. Distributed Cognition. In: The International Encyclopedia of the Social and Behavioral Sciences. 2001, p. 2068-2072. Disponível em: <https://www.sciencedirect.com/science/article/pii/B0080430767016363>.

Acesso em nov. 2016.

IGLESIAS, M. P. F. A tecnologia como mediadora das interações humanas. Hipertextus - Revista digital. Recife: UFPE, n. 3, jun. 2009. Disponível em: $<$ http://www.hipertextus.net/volume3/Marcus-PetronioFernandes-\%20IGLESIAS.pdf $>$. Acesso em abr. 2018.

INSTITUTO BRASILEIRO DE GEOGRAFIA E ESTATÍSTICA. Acesso à internet e à televisão e posse de telefone móvel celular para uso pessoal: 2014. Rio de Janeiro: IBGE, 2016. Disponível em: <http://biblioteca.ibge.gov.br/ visualizacao/livros/liv95753.pdf>. Acesso em ago. 2016.

. Pesquisa Nacional por Amostra de Domicílios Contínua - PNAD Contínua TIC 2016. Rio de Janeiro: IBGE, 2018. Disponível em: $<$ https://agenciadenoticias.ibge.gov.br/media/com_mediaibge/arquivos/c62c9d551 093e4b8e9d9810a6d3bafff.pdf>. Acesso em abr. 2018.

JACKS, N.; SCHMITZ, D. Os meios em Martín-Barbero: antes e depois das mediações. MATRIZes. São Paulo: USP, vol. 12, n. 1, 2018. Disponível em: <http://www.revistas.usp.br/matrizes/article/view/137525/139748>. Acesso em mai 2018.

JENKINS, H. Cultura da Convergência. Tradução: Susana Alexandria. $2^{\mathrm{a}}$ edição. São Paulo: Editora Aleph, 2009, 432p.

JENKINS, H.; GREEN, J.; FORD, S. Cultura da Conexão: Criando valor e significado por meio da mídia propagável. São Paulo: Aleph, 2014, 408p.

JOHN-STEINER, V.; SOUBERMAN, E. Posfácio. In: VIGOTSKI, L. S. A formação social da mente: $O$ desenvolvimento dos processos psicológicos superiores. $7^{a}$ edição. São Paulo: Martins Fontes, 2007, 182p.

KAIESKI, N.; GRINGS, J. A.; FETTER, S. A. Um estudo sobre as possibilidades pedagógicas de utilização do WhatsApp. Revista Renote - Novas Tecnologias na Educação. Porto Alegre: Cinted/UFRGS, vol. 13, n. 2, 2015. Disponível em: $<$ http://seer.ufrgs.br/index.php/renote/article/view/61411/36314>. Acesso em dez. 2017.

KASTRUP, V. A aprendizagem da atenção na cognição inventiva. Psicologia \& Sociedade, 2004, vol. 16, n. 3, p. 7-16. 
KING. A. L. S. et al. Nomophobia: Dependency on virtual environments or social phobia?. Computers in Human Behavior. Vol. 29, ed. 1, jan. 2013, p. 140-144. Disponível em: <https://www.sciencedirect.com/science/article/pii/ S0747563212002282>. Acesso em abr. 2018.

KOCHHANN, A.; FERREIRA, K. C. B.; SOUZA, J. M. de. O uso do WhatsApp coomo possibilidade de aprendizagem: Uma experiência no ensino superior. Educação e Linguagem: (Re) Significando o conhecimento - Anais da Semana de Integração, 2015, vol. 2, n, 1, p. 473-483. Disponível em: <http://www.anais.ueg.br/index.php/semintegracao/article/view/5493>. Acesso em dez. 2017.

LAIRD, T. F. N.; KUH, G. D. Student experiences with information technology and their relationship to other aspects of student engagement. Research in Higher Education, vol. 46, n. 2, 2005. Disponível em: <https://link.springer.com/ article/10.1007/s11162-004-1600-y>. Acesso em nov. 2016.

LEMOS, A. Cidade e mobilidade. Telefones celulares, funções pós-massivas e territórios informacionais. MATRIZes. São Paulo: USP, vol. 1, n. 1, 2007. Disponível em <https://www.revistas.usp.br/matrizes/article/view/38180/40911>. Acesso em out. 2017.

. Cultura da mobilidade. Revista Famecos. Porto Alegre: PUC-RS, $\mathrm{n}^{\circ}$ 40, dez./2009. Disponível em: <http://revistaseletronicas.pucrs.br/ojs/index.php/ revistafamecos/article/viewFile/6314/4589>. Acesso em set. 2017.

LIBÂNEO, J. C.; FREITAS, R. A. M. da M. Vygotsky, Leontiev, Davydov - Três aportes teóricos para a teoria histórico-cultural e suas contribuições para a didática. In: IV Congresso Brasileiro de História da Educação. Eixo temático: 3 - Cultura e práticas escolares, 2006.

LIVINGSTONE, S. Internet literacy: a negociação dos jovens com as novas oportunidades on-line. MATRIZes. São Paulo: USP, vol. 4, n. 2, jan-jul/2011, p. 11-42. Disponível em: <http://www.revistas.usp.br/matrizes/article/view/ 38290/41112>. Acesso em jun. 2016.

LOPES, T. B.; SANTOS, L. G. dos. O uso do GeoGebra como ferramenta auxiliar para estudo da reta tangente a um gráfico. Revista Renote - Novas Tecnologias na Educação. Porto Alegre: Cinted/UFRGS, vol. 14, n. 2, 2016. Disponível em: <http://www.seer.ufrgs.br/index.php/renote/article/view/70637/40063>. Acesso em mar. 2018.

LÜDKE, M.; ANDRÉ, M. E. D. A. Pesquisa em Educação: Abordagens qualitativas. São Paulo: Editora Pedagógica e Universitária, 1986.

MÄDER, G. R. C.; MOURA, H. M. M. O masculino genérico sob uma perspectiva cognitivo-funcionalista. Revista do Gelne. Natal: UFRN, vol. 17, n. 1, 2, 2015. 
Disponível em: <https://periodicos.ufrn.br/gelne/article/view/10173>. Acesso em abr.. 2018.

MANTOVANI, A. M. A ubiquidade na comunicação e na aprendizagem: ressignificação das práticas pedagógicas no contexto da cibercultura. Tese de Doutorado. Programa de Pós-Graduação em Educação, Pontifícia Universidade Católica do Rio Grande do Sul. 2016, 165p.

MARTÍN-BARBERO, J. A comunicação na educação. Tradução: Maria Immacolata Vassallo de Lopes e Dafne Melo. São Paulo: Editora Contexto, 2014, $155 \mathrm{p}$.

Desafios culturais da comunicação à educação. Comunicação \& Educação. São Paulo: ECA/USP, n. 18, 2000. Disponível em: <http://www.revistas.usp.br/comueduc/article/view/36920/39642>. Acesso em nov. 2016.

MARTINELL, A. R.; CASILLAS, M. Una metodología para la incorporación de las TIC al curriculum universitario. In: CASILLAS, M.; MARTINELL, A. R. (coords.). Educación Virtual y Recursos Educativos. Colección Háblame de TIC 3. Córdoba: Editorial Brujas, $1^{a}$ ed., 2016, p. 31-50.

MASIKA, M. M. et al. Use of mobile learning technology among final year medical students in Kenya. Pan-African Medical Journal. 2015, jun, p. 1-12. Disponível em: <http://www.panafrican-med-journal.com/content/ article/21/127/full/>. Acesso em 7 nov. 2016.

MCLUHAN, M. Os meios de comunicação como extensões do homem. Tradução de Décio Pignatari. $1^{\text {a }}$ edição, $15^{\text {a }}$ reimpressão de 1969. São Paulo: Cultrix, 2007, 407p.

MOURA, Adelina M. C. Apropriação do Telemóvel como Ferramenta de Mediação em Mobile Learning: Estudos de Caso em Contexto Educativo. Tese de Doutorado (Ciências da Educação, na Especialidade de Tecnologia Educativa). Instituto de Educação, Universidade do Minho, 2010, 601p.

MUNGUÍA, V. M. Disciplina, ¿factor diferenciador del uso de dispositivos digitales portátiles entre estudiantes universitarios?. In: GONZÁLEZ, R. L.; HERNÁNDEZ, D. H.; SANTOS, A. J. B. Las tecnologías digitales en los contextos educativos - La voz de los estudiantes. Colección Háblame de TIC 4. Córdoba: Editorial Brujas, $1^{a}$ ed., 2017, 192p.

NICOLACI-DA-COSTA, A. M. Revoluções tecnológicas e transformações subjetivas. Psicologia: Teoria e Pesquisa. Vol. 18, n. 2, mai-ago 2002, p. 193-202.

OLIVEIRA, I. A. de; FONSECA, M. J. da C. F.; SANTOS, T. R. L. dos. A entrevista na Pesquisa Educacional. In: MARCONDES, M. I.; TEIXEIRA, E.; 
OLIVEIRA, I. A. de. Metodologias e Técnicas de Pesquisa em Educação. Belém: EDUEPA, 2010, p. 37-53.

OLIVEIRA, M. K. de. Vygostky - Aprendizado e desenvolvimento: Um processo histórico. $4^{\mathrm{a}}$ edição. São Paulo, Editora Scipione, 1998, 111p.

ORGANISTA, J.; SANTOYO, A. S. Aspectos de posesión, permisos y usos educativos de dispositivos portátiles durante el trayecto de primaria a universidad. Apertura - Revista de innovación educativa. Vol. 6, n. 2, 2014. Disponível em: <http://www.udgvirtual.udg.mx/apertura/index.php/apertura/article/view/570>.

Acesso em mar. 2018.

PAIVA, L. F. de; FERREIRA, A. C. C.; CORLETT, E. F. A utilização do WhatsApp como ferramenta para comunicação didática pedagógica no ensino superior. V Congresso Brasileiro de Informática na Educação, 2016. Anais dos Workshops do CBIE. Disponível em: <http://br-ie.org/pub/index.php/ wcbie/article/view/6998/4872>. Acesso em dez. 2017.

PAPADOPOULOS, C. R. A trajetória acadêmica de estudantes universitários diagnosticados com TDAH à luz da Teoria Bioecológica do Desenvolvimento Humano. Tese de Doutorado - Departamento de Educação, Pontifícia Universidade Católica do Rio de Janeiro, 2018, 184p.

PEDRO, L. F. M. G.; BARBOSA, C. M. M. O.; SANTOS, C. M. N. A critical review of mobile learning integration in formal educational contexts. International Journal of Educational Technology in Higher Education, 2018, vol. 15, n. 10. Disponível em: <https://educationaltechnologyjournal.springeropen.com/ track/pdf/ 10.1186/s41239-018-0091-4>. Acesso em mar. 2018.

PINO, A. A interação social: perspectivas sócio-históricas. Idéias, São Paulo, n. 20, p. 49-58, 1993.

PINTO, C. M. "Por um olhar Transhabermasiano: A esfera pública virtual como tecnologia cognitiva". Tese de Doutorado - Departamento de Educação, Pontifícia Universidade Católica do Rio de Janeiro, 2017, 236p.

PRENSKY, M. Digital natives, digital immigrants. On the Horizon. MCB University Press, vol. 9, n. 5, 2001. Disponível em: <https://www.marcprensky. com/writing/Prensky\%20-\%20Digital\%20Natives, \%20Digital\%20Immigrants\% 20-\%20Part1.pdf>. Acesso em mai. 2016.

H. Sapiens Digital: From digital immigrants and digital natives to digital wisdom. Innovate: Journal of Online Education, vol. 5, n. 2, fev-mar., 2009. Disponível em: <https://nsuworks.nova.edu/innovate/vol5/iss3/1/>. Acesso em mai. 2016.

PRESTES, Z. R. Quando não é a mesma coisa: análise de traduções de Lev Semionovitch Vigotski no Brasil: repercussões no campo educacional. Tese de 
Doutorado - Departamento de Educação, Universidade de Brasília, Brasília, 2010, $295 p$.

REGIS, F.; MESSIAS, J. Comunicação, tecnologia e cognição: rearticulando homem, mundo e pensamento. In: REGIS, F. et al. Tecnologias de Comunicação e Cognição. Porto Alegre: Editora Sulina, 2012, p. 23-51.

REGIS, F.; TIMPONI, R.; MAIA, A. Cognição integrada, encadeada e distribuída: breve discussão dos modelos cognitivos na cibercultura. Comunicação, Mídia e Consumo. São Paulo: ESPM, ano 9, vol. 9, n. 26, nov., 2012, p.115-134.

RICHIT, A. et al. Contribuições do software GeoGebra no estudo de cálculo diferencial e integral: uma experiência com alunos do curso de Geologia. Revista do Instituto GeoGebra Internacional de São Paulo. São Paulo: Faculdade de Ciências Exatas e Tecnologia da PUC/SP, vol. 1, n. 1, 2012. Disponível em: $<$ https://revistas.pucsp.br/index.php/IGISP/article/view/8385>. Acesso em mar. 2018 .

ROCHA, C. Por que a França quer banir completamente os celulares das escolas? Portal Nexo, dez., 2017. Disponível em: <https://www.nexojornal.com.br/ expresso/2017/12/12/Por-que-a-Fran\%C3\%A7a-quer-banir-completamente-oscelulares-das-escolas>. Acesso em mar. 2018.

SANCOVSCHI, B.; KASTRUP, V. Práticas de estudo contemporâneas e a aprendizagem da atenção. Psicologia \& Sociedade, 2013, vol. 25 (1), p. 193-202.

SANTAELlA, L. Desafios da ubiquidade para a educação. Revista Ensino Superior. Campinas: Unicamp, abr., 2013. Disponível em: $<$ https://www.revistaensinosuperior.gr.unicamp.br/artigos/desafios-daubiquidade-para-a-educacao >. Acesso em set. 2017.

SELWYN, N. Educação e Tecnologia: Questões críticas. In: FERREIRA, G. M. S.; ROSADO, L. A. S.; CARVALHO, J. S. Educação e Tecnologia: Abordagens críticas. Rio de Janeiro: Universidade Estácio de Sá, 2017, 663p. Disponível em: $\langle$ https://ticpe.files.wordpress.com/2017/04/ebook-ticpe-2017.pdf >. Acesso em abr. 2018.

SERRA, J. P. Manual de Teoria da Comunicação. Covilhã: Universidade da Beira Interior, 2007, 203p.

SIBILIA, P. A escola no mundo hiperconectado: Redes em vez de muros?. MATRIZes. São Paulo: USP, vol. 5, n. 2, 2012. Disponível em: $<$ https://www.revistas.usp.br/matrizes/article/view/38333/41193>. Acesso em out. 2017.

SILVA, A. M. Apropriações sociais e formativas das tecnologias digitais por adolescentes e suas relações com o ensino e aprendizagem na escola. Tese de Doutorado. Programa de Pós-graduação em Educação da Faculdade de Ciências e 
Tecnologia, UNESP/Campus de Presidente Prudente, 2016, 212p.

SILVA, B. H. P.; SAMÁ, S.; LUNARDI, G. L. Motivos de uso e benefícios percebidos pelos estudantes do ensino superior no uso dos dispositivos móveis no ambiente educacional. Revista Renote - Novas Tecnologias na Educação. Porto Alegre: Cinted/UFRGS, vol. 15, n. 2, 2017. Disponível em: <http://www.seer.ufrgs.br/index.php/renote/article/view/79267/46161>. Acesso em out. 2017.

SILVA, T. O.; SILVA, L. T. G. Os impactos sociais, cognitivos e afetivos sobre a geração de adolescentes conectados às tecnologias digitais. Psicopedagogia. Relato de experiência, 2017, vol. 34, ed. 103. Disponível em: $<$ http://www.revistapsicopedagogia.com.br/detalhes/520/os-impactos-sociais-cognitivos-e-afetivos-sobre-a-geracao-de-adolescentes-conectados-as-tecnologiasdigitais>. Acesso em abr. 2018.

SIMMEL, G. Questões fundamentais da sociologia: indivíduo e sociedade. Rio de Janeiro: Jorge Zahar Editora, 2006. 120p.

SOARES, M. Novas práticas de leitura e escrita: letramento na cibercultura. Educação \& Sociedade. Campinas: Unicamp, vol. 23, n. 81, p. 143-160, dez. 2002. Disponível em: < http://www.scielo.br/pdf/es/v23n81/13935>. Acesso em fev. 2018.

SUPRIADI, N. et al. Developing high-order mathematical thinking competency on high school students' through GeoGebra-assisted blended learning. Mathematical Theory and Modeling, vol. 4, n. 6, 2014. Disponível em: <http://www.iiste.org/Journals/index.php/MTM/article/view/13109>. Acesso em mar. 2018.

SOUSA, A. G. M. de. Mobile learning: recetividade e predisposição do ensino superior para a sua utilização. Dissertação de Mestrado, Gestão de Desenvolvimento de Recursos Humanos, Instituto Politécnico do Porto, 2014, 114p.

TEIXEIRA, E.; OLIVEIRA, I. A. de. Cuidados Éticos na Pesquisa. In: MARCONDES, M. I.; TEIXEIRA, E.; OLIVEIRA, I. A. de. Metodologias e Técnicas de Pesquisa em Educação. Belém: EDUEPA, 2010, p. 09-24.

TIMMIS, S. Constant companions: Instant messaging conversations as sustainable supportive study structures amongst undergraduate peers. Computers \& Education, n. 59, 2012, p. 3-18. Disponível em: <https://www.sciencedirect.com /science/article/pii/S0360131511002430>. Acesso em out. 2017.

TORRES, P. L.; IRALA, E. A. F. Aprendizagem colaborativa: teoria e prática. In: TORRES, P. L. (org.). Metodologias para a produção do conhecimento: da concepção à prática. Curitiba: SENAR-PR, 2015, 176p. 
UNESCO. Policy guidelines for mobile learning. Paris: United Nations Educational, Scientific and Cultural Organization, 2013. Disponível em: <http://unesdoc.unesco.org/images/0021/002196/219641E.pdf>. Acesso em ago. 2016.

VAN ZANTEN, A. Pesquisa qualitativa em educação: pertinência, validez e generalização. Perspectiva. Florianópolis, v. 22, n. 01, jan./jun. 2004, p. 25-45.

VÁSQUEZ-CANO, E. Mobile Distance Learning with smartphones and apps in higher education. Educational Sciences: Theory and Practice. Istanbul: Educational Consultancy and Research Center, vol. 14, n. 4, 2014. Disponível em: <https://files.eric.ed.gov/fulltext/EJ1045122.pdf>. Acesso em abr. 2018.

VÁSQUEZ-CANO, E.; SEVILlanO, G. M. L. Posibilidades de uso del smartphone en y para la educación. In: Dispositivos digitales móviles em educacíon: El aprendizaje ubicuo. Madrid: Narcea Ediciones, 2015, cap. 4, p. 68-83.

ZAGO, N. A entrevista e seu processo de construção: reflexões com base na experiência prática de pesquisa. In: ZAGO, N.; CARVALHO, M. P.; VILELA, R. A. T. (orgs.). Itinerários de pesquisa: perspectivas qualitativas em sociologia da educação. Rio de Janeiro: Lamparina, 2011, 309p. 


\section{Apêndices}

\section{Apêndice A - Protocolo de entrevista semiestruturada}

Roteiro para entrevistas com estudantes de graduação da Universidade Federal do Estado do Rio de Janeiro (Unirio) sobre os modos de uso do celular em atividades de estudo

\section{Parte 1. Informações gerais sobre o entrevistado}

- Nome:

- Idade:

- Curso e período em que está matriculado:

Parte 2. Informações gerais sobre o uso do celular

- Qual o tipo de dispositivo (sistema operacional - iOS, Android, Windows)?

- Qual o tipo de conexão que costuma utilizar (3G/4G, wi-fi, ambas)?

- Como você resume sua relação com o celular?

- Frequência de uso do celular em atividades gerais (todos os dias; muitas vezes na semana; poucas vezes na semana; raramente; nunca).

a) Ligações telefônicas

b) Navegar em sites

c) Acessar redes sociais (Facebook, Twitter, Instagram, outros)

d) Ler e enviar e-mails

e) Ler e enviar mensagens instantâneas (WhatsApp, Messenger, outros)

f) Ouvir música

g) Fotografar

h) Assistir a vídeos

i) Fazer vídeos

j) Jogar

k) Outros (especificar):

Parte 3. Uso do celular em atividades relacionadas à vida acadêmica e ao estudo

- Em quais atividades relacionadas à vida acadêmica e ao estudo você costuma usar o celular?

- Poderia descrever como você utiliza o dispositivo nessas atividades? 
- Onde você costuma realizar essas atividades?

- Por que você usa o celular para realizar essas atividades?

- Para alguma dessas atividades você prefere o celular? Quais e por quê?

- Que vantagens e desvantagens você percebe em utilizar o celular nessas atividades?

- Você utiliza o celular em sala de aula? Algum professor já incentivou ou propôs alguma atividade com o aparelho? Em caso positivo, que tipo de atividade?

- Como foi para você realizar essas atividades?

- Já teve ou já presenciou algum problema com professor, de reclamação ou proibição?

- Como você vê o uso do celular em sala de aula (gostaria de usar mais, menos, atrapalha, ajuda)?

- Você identifica uma ou mais atividades realizadas com o celular que se relacionam especificamente para sua área de estudo? Se sim, quais?

- Que diferenças no estudo e na aprendizagem você percebe com o uso do celular?

- Há uma ou mais atividades de estudo que você gostaria de realizar com o celular, mas não realiza por algum motivo?

- Como você se sentiria se não pudesse mais utilizar o celular para realizar atividades de estudos? Explique.

\subsection{Atenção}

- Como é para você manter a atenção nessas atividades realizadas com o celular? Fácil, difícil? Explique.

- Quais estratégias você usa para manter a atenção quando utiliza o celular para estudar?

- O que você faz quando tem alguma interrupção (p.ex.: notificação de WhatsApp, rede social ou e-mail)? É fácil ou difícil voltar à atividade anterior? Quando é mais fácil e quando é mais difícil?

\section{Parte 4. Perguntas de encerramento}


- Para terminar, em sua opinião, de modo geral qual seria o papel do celular na aprendizagem?

- Depois da nossa conversa, se você pudesse destacar três palavras que vêm a sua cabeça quando você pensa no uso do celular em atividades de estudo, quais seriam?

- Gostaria de acrescentar ou falar de algum ponto não contemplado pela pesquisa?

- Você tem alguma dúvida sobre a pesquisa?

(FIM) 
Apêndice B - Termo de Consentimento Livre e Esclarecido - TCLE

PONTIFÍCIA UNIVERSIDADE CATÓLICA DO RIO DE JANEIRO

Programa de Pós-Graduação em Educação

PUC TE TERO DE CONSENTIMENTO LIVRE E ESCLARECIDO

Prezado/a:

Gostaríamos de convidá-lo/a para participar voluntariamente da pesquisa apresentada a seguir.

Pesquisa: "Percepções de universitários sobre usos do celular em atividades de estudo"

\section{Pesquisadores:}

\section{Mestranda: Daniela de Oliveira Pereira Orientadora: Profa. Dra. Rosália Duarte}

Justificativa: Trata-se de um estudo que visa refletir acerca das percepções de universitários sobre o uso das tecnologias móveis, especificamente o celular, no contexto acadêmico.

Objetivos: A pesquisa busca identificar as percepções de universitários sobre seus modos de uso do celular em atividades de estudo, os possíveis ganhos que eles identificam nestes usos e se há diferenças entre estudantes das áreas das humanidades e das exatas e tecnologia.

Metodologia: Entrevistas com estudantes de graduação da Universidade Federal do Estado do Rio de Janeiro (Unirio) registradas em áudio, com duração média de 30 minutos, realizadas no espaço da universidade ou em local de preferência do participante, a ser combinado com a pesquisadora. Na ocasião da entrevista poderão ser feitos registros audiovisuais das atividades realizadas pelo participante com o celular, preservando sua identidade facial e apenas para consulta da pesquisadora. Será também utilizado aplicativo de mensagens instantâneas para envio de áudios e prints das telas do celular à pesquisadora, que serão utilizados de forma anônima. Caso necessário, poderá ser agendado mais um encontro com o entrevistado.

Riscos e Benefícios: No que se refere aos riscos da pesquisa, que são mínimos, existe a possibilidade de algum tipo de inibição ou embaraço dos participantes ao falarem sobre o uso de seus celulares pessoais, e também de sua identificação na pesquisa. Os procedimentos buscarão evitar estes riscos: os participantes escolherão o melhor local e hora para darem a entrevista, poderão encerrá-la a qualquer momento, terão sua identidade preservada nas transcrições e, no uso dos dados, as declarações utilizadas em contexto acadêmico serão mencionadas de forma anônima. Os participantes terão acesso aos resultados desta pesquisa e poderão ser 
beneficiados com estudos sobre os ganhos relacionados ao uso de tecnologias móveis em atividades acadêmicas.

- Este termo deverá ser assinado em 2 (duas) vias, uma que será entregue ao/à voluntário/a e outra para os arquivos da pesquisa.

- Em caso de participantes menores de 18 anos de idade, segundo as normas do Conselho Nacional de Saúde, este termo deverá ser assinado pelos pais ou responsáveis. Nesta situação, o participante deverá assinar um Termo de Assentimento.

$\mathrm{Eu}$,

de maneira voluntária, livre e esclarecida, concordo em participar da pesquisa acima identificada. Estou ciente dos objetivos do estudo, de como serão realizadas as entrevistas, de que as informações prestadas serão utilizadas apenas neste estudo e de que poderei solicitar esclarecimentos a qualquer momento. Fui informado(a) de que se trata de pesquisa de mestrado em andamento no Programa de Pós-Graduação em Educação da PUC-Rio. Está claro que minha participação é isenta de despesas e que minha imagem e meu nome não serão publicados sem minha prévia autorização por escrito. Estou de acordo com a audiogravação da entrevista e com os registros audiovisuais do meu uso do celular, a serem cedidos para fins de registros acadêmicos. Estou ciente de que, em qualquer fase da pesquisa, tenho a liberdade de recusar a minha participação ou retirar meu consentimento, sem nenhuma penalização ou prejuízo que me possam ser imputados.

Daniela de Oliveira Pereira, mestranda

Profa. Dra. Rosália Duarte, orientadora

[assinatura do/a aluno/a voluntário/a]

Nome completo:

E-mail: Tel.

Identificação (RG):

Rio de Janeiro, de de 2017. 


\section{Apêndice C - Relação de códigos criados no Atlas.ti para análise dos dados}

\begin{tabular}{|c|c|}
\hline \multicolumn{2}{|c|}{ Códigos (total: 40) } \\
\hline Acesso a informação e conteúdos & Foto do quadro/material do colega \\
\hline Atenção & Fotografia \\
\hline Atuação/postura dos professores & Ganhos \\
\hline Celular como fonte de distração & Gravação de áudio \\
\hline Celular como fuga & Humanas \\
\hline Celular como sinônimo de internet & Leitura no celular \\
\hline Celular na educação & Leitura no papel/computador \\
\hline Celular para organização & Mobilidade \\
\hline Celular para revisão/edição rápida & Pesquisa \\
\hline Compartilhamento de informações & Praticidade \\
\hline Computador x celular & Prejuízos \\
\hline Comunicação/acesso instantâneo & Presença constante do celular \\
\hline Dependência & $\begin{array}{c}\text { Recomendações de amigos e/ou } \\
\text { professores }\end{array}$ \\
\hline Desvantagens & Redução de custos \\
\hline Dificuldades com o celular & Relação com o celular \\
\hline Elaboração de trabalhos & Sentimento sem o celular \\
\hline Estudo em grupo & Uso em sala de aula \\
\hline Exatas & Uso no transporte público \\
\hline Excesso de informação & Vantagens \\
\hline Facilidade & Videoaulas \\
\hline
\end{tabular}


Apêndice D - Relação de códigos do grupo 'Aplicativos' criados no Atlas.ti para análise dos dados

Grupo de códigos: Aplicativos

\begin{tabular}{|c|c|c|}
\hline & \multicolumn{2}{|c|}{ Códigos (total: 14) } \\
\hline & Agenda/calendário & Google Drive \\
\hline & Caderno/notas & Google Fotos \\
\hline & Calculadora & One Drive \\
\hline & Dropbox & Scanner \\
\hline & E-mail & WhatsApp \\
\hline 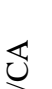 & Facebook & Word \\
\hline$\frac{\sqrt{3}}{6}$ & GeoGebra & YouTube \\
\hline
\end{tabular}

